Halina MANIKOWSKA

Instytut Historii PAN

\title{
Topos czy rzeczywistość? O czarnej śmierci w Dekameronie raz jeszcze
}

\author{
I \\ „Prolog” jako źródło historyka
}

Najbardziej sugestywny i literacko doskonały opis czarnej śmierci w 1348 roku jest spośród świadectw współczesnych wielkiej epidemii jedynym znanym powszechnie i od dawna. I to on do dziś narzuca naszej wyobraźni obraz jednej z największych w dziejach ludzkości pandemii. Nie potrzeba na to stwierdzenie lepszego dowodu niż opracowane w niemal 80 językach hasło wikipedii: „Czarna śmierć", którego autorzy w przypadku najobszerniejszych artykułów (sprawdziłam kilkanaście z nich napisanych alfabetem łacińskim) albo, i najczęściej, odnoszą się wprost do Dekameronu, a nawet go cytują, albo przynajmniej podają do niego link.

Zawierający ten opis „Prolog”, a ściślej „Wstęp do Dnia Pierwszego” bardzo wcześnie stał się ważnym źródłem wiedzy dla kronikarzy i autorów różnego typu ksiąg rodzinnych (libri di famiglia) piszących czy tylko wspominających o epidemii w 1348 r. Zapewne korzystał z niego Marchionne di Coppo Stefani (właściwie Baldassarre Bonaiuti), komponując w początku lat 80. XIV w. swoją Cronaca fiorentina, której fragment dotyczący czarnej śmierci należy z pewnością do najlepiej znanych z jego dzieła ${ }^{2}$. Wprost przywołuje Boccaccia w opisie poprzedzającym rady, jak bronić się przed chorobą w czasie epidemii, Giovanni di Pagolo Morelli, którego Ricordi — rodzaj pouczeń dla synów — z przełomu XIV i XV w. należą do najwyżej cenionych przez historyków Florencji i cywilizacji komunalnej schyłku średniowiecza ksiąg rodzinnych ${ }^{3}$.

\footnotetext{
${ }^{1}$ W artykule używać będę tytułu tego fragmentu Dekameronu — „Prolog” — ponieważ taki figuruje w wydaniach w języku polskim w tłumaczeniu Edwarda Boyé i opracowaniu Mieczysława Brahmera, i taki funkcjonuje też w literaturze przedmiotu w różnych językach. W wydaniach włoskich słowo wprowadzające do całości dzieła nosi tytuł „Proemio”, zaś „Prolog” to „Introduzione” (alla Prima giornata).

2 Marchionne di Coppo Stefani, Cronaca fiorentina, wyd. N. Rodolico, Città di Castello 1903, Rerum italicarum scriptores, t. 30, cz. 1 [dalej: Marchionne].

3 „Negli anni di Cristo 1348 fu nella città di Firenze una grande mortalità di persone umane le quali morivano di male pestilenziale; e molti gran fatti se n'ode dire dalle persone antiche e assai se ne truova iscritti; e fra gli altri ne scrive assai copiosamente messer Giovanni Bocacci in un libro che fece di cento novelle, ed è nel prencipio del libro" - Giovanni di Pagolo Morelli, Ricordi, wyd. V. Branca, Collezione in Ventiquattresimo (wyd. 2), Firenze 1969, s. 290-301. Na listę autorów najwcześniej wykorzystujących bądź odsyłających do opisu Boccaccia, poza Marchionne i Morellim, trzeba też wpisać Machiavellego, Istorie fiorentine (L. II, cap. XLII: „,... nel corso del qual tempo seguì quella memorabile pestilenzia da messer Giovanni Boccaccio con tanta eloquenzia celebrata...”) czy Francesco Rondinellego, Relazione del contagio stato in Firenze l'anno 1630 e 1633, Firenze 1634; zob. J. Grimm, Die literarische Darstellung der Pest in der Antike und in der Romania, München 1965, s. 117 n.
} 
W nowoczesnej historiografii opowieść Boccaccia nie tylko od początku traktowana była jako ważne źródło historyczne, ale wręcz przyczyniła się w ogromnym stopniu do podjęcia badań nad czarną śmiercią, rzecz jasna przede wszystkim we Włoszech i samej Florencji ${ }^{4}$. Jego opis symptomów choroby, jej przebiegu i dróg zakażenia uważany jest — pośród wyszłych spod pióra nielekarzy — za jeden $\mathrm{z}$ najbardziej poprawnych i jest ważnym argumentem za dżumą w toczonych aktualnie sporach o diagnozę choroby i etiologię ,czarnej śmierci”'. Do dziś powraca się, choć raczej już tylko na marginesie innych rozważań, do pytania, czy jest to opis naocznego świadka (przebywającego we Florencji lub przynajmniej szczegółowo informowanego przez ojca) ${ }^{6}$, czy „tylko” literacka fikcja, wykorzystująca bogatą tradycję i topikę tekstów o zarazie, poczynając od uznanego za ich matrycę słynnego Tukidydesowego opisu zarazy w Atenach (prawdopodobnie tyfusu) ${ }^{7}$. Najwięcej badaczy piszących o czarnej śmierci, a zwłaszcza ci, dla których „Prolog” nie jest centralnym tematem studiów naukowych i którzy swoje konstatacje opierają na literaturze przedmiotu, sytuuje się ,po środku”: nie jest pewne, czy Boccaccio był we Florencji (źródła potwierdzają jego obecność w mieście w 1349 r.), ale by być świadkiem zarazy, nie było to przecież konieczne; ponadto, o przebiegu epidemii we Florencji miał informacje od najbliższych, stracił także wielu przyjaciół; nie da się zakwestionować autentyczności zjawisk i faktów przez niego opisanych, rzeczywistości szoku, którą tak sugestywnie oddaje, ale zarazem nie można jego przekazu traktować jako naocznego świadectwa, raportu, bo wykorzystuje wcześniejszą literaturę z jej charakterystyczną topikąa

Od co najmniej dwustu siedemdziesięciu lat ${ }^{9}$, od odkrycia zależności „Prologu” od fragmentu Wojny peloponeskiej Tukidydesa prowadzi się badania nad znajomością przez Boccaccia tekstów, których ślady (zapożyczenia czy tylko inspiracje) wydawały się poprzednim, dobrze obeznanym z literaturą starożytną pokoleniom badaczy aż nadto dobrze widoczne w opisie florenckiej zarazy. Lista tych tekstów się wydłużała, co nieuniknione, gdy jedni wzorowali się drugich: opis Tukidydesa przejął Lukrecjusz (De rerum natura, długo uważane za główne źródło „Prologu”"10), od niego przepisywał z kolei Makrobiusz (Saturnalia), w średniowieczu dorzuci jeszcze swój wspaniały akapit o dżumie

\footnotetext{
${ }^{4}$ Poczynając od do dziś wykorzystywanej pracy F. Carabellese, La peste nera del 1348 e le condizioni della sanità pubblica in Toscana, Rocca San Casciano 1897; por. także J.M. Rigg, Introduction to The Decameron by Giovanni Boccaccio, London 1903. Z późniejszych książek ważna zwłaszcza The Black Death: A Turning Point in History?, red. W. Bowsky, New York 1971.

${ }^{5}$ Na przełomie XX i XXI w. coraz więcej badaczy, w tym historyków medycyny, zaczęło zgłaszać wątpliwości co do charakteru epidemii w 1348 r., podważając pewność, że była to dżuma. Odkrycie w połowie lat 70 wirusa Ebola i kolejne epidemie choroby przez niego wywołanej w Afryce nasunęły części badaczy przypuszczenie, że także pandemia 1348-1350 r. była wywołana przez ten lub podobny wirus (S. Scott, C.J. Duncan, Return of the Black Death: The World's Greatest Serial Killer, Chichester 2004; ale ogłosili to już w 2001 r.). Podjęte w ostatnich latach w różnych miejscach Europy badania DNA materiału kostnego ofiar zarazy 1348 r. potwierdzają jednak, że była to dżuma (Yersinia pestis); podsumowanie badań w: S. Haensch, R. Bianucci, M. Signoli, M. Rajerison, M. Schultz et al., Distinct Clones of Yersinia pestis Caused the Black Death, PLoS Pathog 6 (10), <http://www.plospathogens.org/article/info\%3Adoi\%2F10.1371\%2F journal.ppat.1001134> [dostęp: 24.10.2014]. Najważniejszy głos historyka w tej debacie: S.K. Cohn Jr, The Black Death: End of a Paradigm, „The American Historical Review”, 107, 2002, nr 3, s. 702-738, zwł. od s. 711.

${ }^{6}$ Spośród najbardziej wpływowych, którzy to podkreślali, wymienić w pierwszym rzędzie trzeba takich badaczy jak: Vittore Branca, Carlo Muscetta i Philip Ziegler (ciągle wznawiana, wydana po raz pierwszy w 1969 r. praca The Black Death). Referuje ich poglądy oraz bardziej sceptyczne czy relatywizujące stanowiska C. De Paolo, Epidemic Disease and Human Understanding: A Historical Analysis of Scientific and Other Writings, Jefferson, NC 2006, s. 62 n.

7 Zob. zwłaszcza analizę G. Getto, La peste del „Decameron” e il problema della fonte Lucreziana, „Giornale storico della letteratura italiana”, 135, 1958, s. 507-523 (korzystałam z przedruku w: tenże, Immagini e problemi di letteratura italiana, Milano1966, Biblioteca europea di cultura, t. 3, s. 51-68.

${ }^{8}$ Przykładem takiego ujęcia jest wstęp tłumacza, G.H. McWilliama, do wydania w języku angielskim Dekameronu, w II wydaniu dzieła w „Pinguin Classics” (2003).

9 D.M. Manni, Istoria del Decamerone di Giovanni Boccaccio, Firenze 1742; zob. też G.B. Baldelli, Vita di Giovanni Boccacci, Firenze 1806; P.-L. Ginguené, Histoire littéraire d'Italie, t. 3, Paris 1811. Ten wczesny etap badań referuje zwięźle G. Getto, La peste, s. 51-56. Zob. także J. Grimm, Die literarische Darstellung, zwłaszcza s. $111 \mathrm{nn}$.

10 Zob. zwłaszcza, C.A. Traversi, Raffronto fra la peste di Tucidide, di Lucrezio e di Giovanni Boccaccio, „Il Propugnatore”, XIV - cz. I, 1881, s. 303.
} 
Paweł Diakon — też ponoć na Lukrecjuszu się wzorujący ${ }^{11}$, a do literackiego toposu zarazy przyłożyli się ponadto Wergiliusz, Owidiusz, Liwiusz, Seneka, Lukan i Syliusz Italikus. Znakomity to materiał na seminarium wprowadzające studentów w zawiłości filiacji, odwzorowań, inspiracji i, powiedzielibyśmy dzisiaj, plagiatów.

Poważne wątpliwości co do bezpośredniej znajomości De rerum natura przez Boccaccia zaczęto zgłaszać już na początku XX w., a inspirowane poszukiwaniem źródeł „Prologu” studia porównawcze nad opisami dżumy doprowadziły w końcu Giovanniego Getto do konkluzji, że „,czarna śmierć stanowiła, jednym słowem, prawdziwy topos, złożony ze stałych, obowiązkowych elementów temat literacki, kanoniczną ekphrasis, którą mógł wykorzystać Boccaccio — pewien, że znajdzie w niej nienaruszalny model, syntezę najbardziej autorytatywnej tradycji”'12. Mając osobiste doświadczenie zarazy, nie musiał sięgać do klasyków po fakty, natomiast zaczerpnął od nich formę, z niektórych zaś wyobrażeń obecnych $\mathrm{w}$ tym utrwalonym na długo przed nim modelu opisu zrezygnować musiał, zarówno dla prawdy, jak i racji artystycznych, wyznaczających „Prologowi” określone miejsce i cel w całości dzieła ${ }^{13}$.

Jeszcze inaczej to miejsce, a zatem i interpretację treści „Prologu”, wyznaczają niektórzy badacze humanizmu. Co najmniej kilkoro z nich zaproponowało analityczną interpretację „Prologu” Boccaccia i listów Petrarki dotyczących czarnej śmierci — w różnym co do charakteru i obszerności kontekście (ich twórczości, kronikarstwa i literatury epoki, teologii i nauczania Kościoła itd.) — zmierzającą czy to do udowodnienia nowatorstwa i wielkiego wkładu obu genialnych autorów do filozofii, etyki, psychologii bądź nawet, i także, historii, czy też — odwrotnie — do pomniejszenia tego znaczenia ${ }^{14}$. Wspólną konkluzją jest uznanie tych tekstów za mało reprezentatywne dla epoki, stawiające trudne dla „zwykłego" historyka pytanie o relacje między percepcją rzeczywistości u obu autorów a percepcją innych ludzi należących do tego samego społeczeństwa, wymagające wzięcia pod uwagę poetyki ich wypowiedzi jako medium pomiędzy nimi a ich czytelnikami Czy wyklucza więc ona lub przynajmniej mocno ogranicza wykorzystanie tych tekstów przez historyka?

Dla poniższych rozważań ważne mogą być zwłaszcza dociekania badaczy humanizmu dotyczące historiozofii Boccaccia. Timothy Kircher, zestawiając narrację Matteo Villaniego — autora najważniejszego kronikarskiego opisu czarnej śmierci we Florencji ${ }^{15}$ - z opisem dżumy w Dekameronie, stwierdza, że Boccaccio pisze o zdarzeniach, których mógł być świadkiem, w sposób zapowiadający nowe podejście do historii. Jest ono inne od podejścia autorów klasycznych i średniowiecznych, świadomie bowiem wymaga od czytelnika, by stworzył własną ocenę tego, o czym historyk twierdzi, że jest prawdą historyczną. Villani traktuje zdarzenia historyczne jako symbole prawd eschatologicznych, podczas gdy humaniści - idąc tu za historykami starożytnymi - zmierzają do badania zjawisk współczesnych poza ich znaczeniem doktrynalnym. „To co pozwala zrozumieć historię zarazy, to - dla Boccaccia — nie kościelna interpretacja zdarzeń, lecz raczej świadomość tego, co Heidegger nazwałby Geschichtlichkeit ludzkiej egzystencji”"16.

\footnotetext{
11 Zależność „Prologu” od Historii Longobardów zauważył dopiero lepiej obeznany z literaturą średniowieczną V. Branca, Boccaccio medievale, Firenze1956, s. 209-213.

${ }^{12}$ G. Getto, La peste, s. 65 n. Wszystkie cytaty w języku polskim, jeśli nie podano tłumacza, są przekładem autorki artykułu.

13 Tamże, s. 66-68.

${ }_{14}$ Zob. ostatnio: T. Kircher, The Poet's Wisdom: The Humanists, the Church, and the Formation of Philosophy in the Early Renaissance, Leiden 2006, Brill's Studies in Intellectual History, t. 133, gdzie dalsza literatura i prezentacja różnych stanowisk. W dyskusji toczonej w ostatnich kilkudziesięciu latach historyk ma do wyboru generalnie dwa stanowiska, wywodzące się od Eugenio Garina i Paula Oskara Kristellera. Zob. ostatnie jej podsumowanie: J. Hankins, Garin and Paul Oskar Kristeller: Existentialism, Neo-Kantianism, and the Post-War Interpretation of Renaissance Humanism, w: Eugenio Garin: Dal Rinascimento all'Illuminismo, red. M. Ciliberto, Roma 2011, s. 481-505, dostepne także: http://dash.harvard. edu/bitstream/handle/1/5128475/Hankins\%20\%281\%29.pdf?sequence=1 [dostęp: 10.03.2014].

${ }_{15}$ M. Villani, Cronica (con la continuazione di Filippo Villani), wyd. G. Porta, t. 1-2, Parma 1995.

${ }^{16}$ T. Kircher, The Poet's Wisdom, s. 48 n. Jego zdaniem, i dla Boccaccia, i dla Petrarki zaraza stała się okazją do zerwania z metafizycznymi pewnikami.
} 
Historycy, dosyć długo nie przywiązujący wagi do badań historyków literatury i krytyków literackich nad tym fragmentem Dekameronu, potraktowali go jako niewymagające głębszej krytyki wewnętrznej pierwszorzędne źródło historyczne i zabrali się do weryfikacji jego wiarygodności, konfrontując dosłowną lekturę opisu Boccaccia z rekonstruowaną przez nich „rzeczywistością historyczną"”. „Prolog” narzucił więc również kwestionariusz badań nad czarną śmiercią, zwłaszcza w monografiach dotyczących wybranego miasta czy regionu włoskiego. Punktem odniesienia pozostaje do dziś1 ${ }^{18}$. Najbardziej zwięzłe podsumowanie wieloletnich badań nad czarną śmiercią, poświęconych m.in. Florencji, Bolonii, Sienie czy Orvieto sprowadza się do stwierdzenia, że życie nie zamarło, chaos nie ogarnął całości życia społecznego, a władze, urzędy i trybunały z reguły panowały nad sytuacją w tym przynajmniej, co dotyczyło ich funkcjonowania. Tę rewizję obrazu Boccaccia na dobre rozpoczął w końcu XIX w. Francesco Carabellese. Późniejsze badania, prowadzone intensywnie w drugiej połowie ubiegłego stulecia: m.in. Alberto B. Falsiniego ${ }^{19}$, Gene Bruckera, Ann Carmichael ${ }^{20}$, Katharine Park ${ }^{21}$, jeśli mowa o Florencji, oraz prace poświęcone innym miastom pogłębiły już tylko rozbieżności między tym, co wyczytano w Dekameronie, a tym, co przekazują źródła innej zgoła natury²2.

Dla historyka świadomego konsekwencji, jakie dla jego badań mają studia krytyczno-literackie czy historyczno-filozoficzne nad Dekameronem, a zwłaszcza nad „Prologiem”, sięganie doń jako do źródła historycznego staje się prawdziwym wyzwaniem z dwóch co najmniej powodów. Po pierwsze, historycy literatury proponują różne odczytanie florenckiego arcydzieła. Ma ono, z jednej strony, reprezentować chrześcijańską wizję moralności (najbliższą nauczaniu i duchowości augustianów eremitów) — w tym sensie można je uznać za kontynuację Boskiej Komedii Dantego — z drugiej, zalicza się je do czysto rozrywkowej ,literatury ucieczki”. Najczęściej wszakże uważa się, że wielkość Dekameronu polega na bogactwie i pomieszaniu konwencji. Mamy więc i eskapizm, i realizm, bezbożność i moralizatorstwo, przesłania — do wyboru — chrześcijańskie, nostalgiczne, historyczne ${ }^{23}$. Po drugie, nie ułatwiają podjęcia tego wyzwania metody krytyki i analizy późnośredniowiecznych źródeł narracyjnych, wyraźnie słabszej próby niż te stosowane do kronik i innych narracji wczesnośredniowiecz-

\footnotetext{
17 Wymienić tu należy w pierwszym rzędzie cyt. pracę F. Carabellese. Wielokrotnie z taką lekturą spotykamy się także na kartach obszernego artykułu zbiorowego autorstwa, La peste nera, w: Morire di peste: testimonianze antiche e interpretazioni moderne della "peste nera» del 1348, red. O. Capitani, Bologna 1995, Il mondo medievale. Studi di storia e storiografia. Sezione di storia delle istituzioni, della spiritualità e delle idee, t. 23, s. 100-167.

${ }^{18}$ Uwaga ta dotyczy szerokiej problematyki badań historycznych nad czarną śmiercią, zwłaszcza, ale nie wyłącznie, we Florencji — od skoncentrowanej na kwestiach medycznych i sanitarnych po historię mentalności. Wśród najważniejszych bądź dających dobry przegląd literatury przedmiotu prac por.: E. Carpentier, Une ville devant la peste: Orvieto et la Peste noire de 1348, Paris 1962; W.M. Bowsky, The Impact of the Black Death upon Senese Government and Society, „Speculum”, 39, 1964, nr 1, s. 1-34; La peste nera: dati di una realtà ed elementi di una interpretazione. Atti del XXX Convegno storico internazionale, Todi, 10-13 ottobre 1993, Spoleto 1994; Morire di peste, dz. cyt.; S.K. Wray, Communities and Crisis: Bologna during the Black Death, Leiden-Boston 2009; G. Brucker, Florence and the Black Death, w: Boccaccio: secoli di vita. Atti del Congresso internazionale Boccaccio 1975, Università di California, Los Angeles, 17-19 ottobre 1975, red. M. Cottin-Jones, E.F. Tuttle, Ravenna1977, s. 21-30; J. Henderson, The Black Death in Florence: Medical and Communal Responses, w: Death in Towns: Urban Responses to the Dying and the Dead, red. S. Basset, London-New York 1992, s. 136-150; tenże, Women, Children and Poverty in Florence at the Time of the Black Death, w: Poor Women and Children in the European Past, red. J. Henderson and R. Wall, New York 1994, s. 160-179.

19 A.B. Falsini, Firenze dopo il 1348: le conseguenze della Pesta Nera, „Archivio storico italiano”, 130, 1971, s. $425-503$.

20 A.G. Carmichael, Plague and the Poor in Renaissance Florence, Cambridge-New York 1986.

${ }^{21}$ K. Park, Doctors and Medicine in Early Renaissance Florence, Princeton 1985.

22 Zob. J.P. Byrne, The Black Death, Westport, CT 2004, Greenwood Guides to Historic Events of the Medieval World.

${ }^{23}$ Zob. klasyfikację stanowisk poszczególnych badaczy w: R. Hollander, The Decameron Proem, w: The Decameron First Day in Perspective: Volume One of the Lecturae Boccaccii, red. E. Weaver, Toronto 2004, s. 14 n. Także program konferencji „rocznicowej” (2013), zorganizowanej w Toronto przez tamtejszą placówkę Włoskiego Instytutu Kultury, na pierwszym miejscu tematów umieszcza „Opposition in the Decameron: the tragic and the comic grotesque; philogyny and misogyny; the useful and the pleasurable; the marvellous and the true" $<$ http://www.iictoronto.esteri.it/IIC_Toronto/webform/Scheda Evento.aspx?id=727> [dostęp: 19.05.2015].
} 
nych. Obfitość późnośredniowiecznych tekstów obok ogromu zasobów archiwalnych miast włoskich zdaje się zwalniać z wysiłku analitycznego i interpretacyjnego.

Historycy z reguły nie dysponują właściwymi narzędziami ani do głębszej lektury i bezpiecznej interpretacji arcydzieł literackich, ani do pełnej kontroli wywodów historyków literatury i krytyków. Dobrą ilustracją tego są np. rozbieżne interpretacje początkowego fragmentu opisu czarnej śmierci: „Dico adunque che già erano gli anni della fruttifera Incarnazione del Figliuolo di Dio al numero pervenuti di milletrecentoquarantotto, quando nella egregia città di Fiorenza, oltre a ogn'altra italica bellissima, pervenne la mortifera pestilenza (...)"24. Historyk dostrzega tu styl kronikarski, uwiarygadniający opowieść i wyłączający ją z rejestru fikcji. Historyk literatury tymczasem zwraca uwagę na dwa zestawione ze sobą (w dodatku rymujące się) antonimy: fruttifera (Incarnazione) i mortifera (pestilenza), które sprawiają, że mamy do czynienia $\mathrm{z}$ grą konwencją i kronikarska $\mathrm{w}$ formie datacja wydarzenia może być interpretowana jako „,ironiczne podkreślenie dokonującego się właśnie rozkładu ciał”25.

Historyk powinien mieć zatem na uwadze miejsce „Prologu” w całości dzieła i wynikające zeń kierunki interpretacji. Nie może zapominać, że tak silnie przemawiający do wyobraźni opis czarnej śmierci to tylko, jak zapewnia Boccaccio, „brieve noia”, po której „graziosissime donne” doczekają się obiecanych im ,la dolcezza e il piacere”. Że opis czarnej śmierci pełni przede wszystkim funkcję prologu, etapu na drodze prowadzącej czytelnika do locus amoenus ${ }^{26}$ : „Questo orrido cominciamento vi fia non altramenti che a' camminanti una montagna aspra e erta, presso alla quale un bellissimo piano e dilettevole sia reposto, il quale tanto più viene lor piacevole quanto maggiore è stata del salire e dello smontare la gravezza". Mówiąc krótko: obraz miasta pogrążonego w chaosie, w którym rządzi strach, a cywilizacyjny porządek i moralność zastąpiły społeczna anarchia i odczłowieczone zachowania, jest konieczny, by pokazać w całej okazałości la brigata, która wybiera czyste, niezepsute powietrze wsi toskańskiej, trzyma się hierarchii społecznych, a przede wszystkim cywilizowanego porządku życia: „La nostra brigata dal primo dì fino a questa ora stata onestissima” (VI, Concl.) ${ }^{27}$.

Musi też historyk pamiętać o zasygnalizowanej już w Proemio innej pladze, która w opowieściach protagonistów Dekameronu będzie tą właściwą: aegritudo amoris, la malattia d'amore. By móc właściwie zinterpretować opis czarnej śmierci, trzeba więc go zestawić z Boccacciańską wersją toposu choroby miłosnej i razem z nią analizować ${ }^{28}$.

Historycy, rzecz jasna, od dawna nie tylko korzystają z dzieł literackich jako źródeł historycznych, ale uważają je za pierwszorzędne w badaniach nad historią kultury, a historią mentalności w szczególności. Od lat też proponują metody krytyczne pozwalające analizować je z uwzględnieniem konwencji, retoryki czy poetyki, a nie tylko czytać dosłownie bądź jako jeszcze jedno źródło narracyjne,

\footnotetext{
${ }^{24}$ Wszystkie cytaty z „Prologu” podaję w języku włoskim ze względu na niedosłowność tłumaczenia Edwarda Boyé.

${ }^{25}$ G. Mazzotta, The World at Play in Boccaccio's Decameron, Princeton 1986, s. 18.

${ }^{26}$ Zob. A.S. Bernardo, The Plague as Key to Meaning in Boccaccio's Decameron, w: The Black Death: The Impact of the Fourteenth-Century Plague, red. D. Williman, Binghampton, N.Y. 1982, s. 39-64.

27 J.H. Potter, Five Frames for the Decameron: Communication and Social Systems in the Cornice, Princeton 1982, s. 6, stwierdza, że kontrast pomiędzy porażającym horrorem opisem czarnej śmierci a pogodnym życiem protagonistów Dekameronu jest jedną z tajemnic książki.

${ }^{28}$ Zob. zwłaszcza tamże, s. 30 nn.; M. Marcus, Seduction by Silence: A Gloss on the Tales of Masetto [Decameron III, 1] and Alatiel [Decameron II, 7], „Philological Quarterly”, 58, 1979, nr 1, s. 8, 9; J. Levenstein, Out of Bounds: Passion and the Plague in Boccaccio's Decameron, ,Italica”, 73, 1996, nr 3, s. 313-335; M. Calabrese, Men and Sex in Boccaccio's Decameron, „Medievalia et Humanistica. Studies in Medieval and Renaissance Culture”, New Series, t. 28: Ethnicity and Self Identity, red. P.M. Clogan, Lanham, MD — Oxford 2002; oraz cyt. artykuł A.S. Bernardo. G. Mazzotta — z grubą jednak przesadą - uważa, że remedia na miłosną melancholię, które przywołuje w „Proemio” Boccaccio, są identyczne jak te, które zalecali stosować w czasie zarazy Tommaso Del Garbo i Giovanni Dondoli (Dondi) (G. Mazzotta, The World at Play, s. 32). W istocie chodzi w „Proemio” tylko o tryb życia wypełniony radością i przynoszący ulgę, nie ma tu mowy o diecie, higienie itd. Por. Come si debba vivere in tempo di Pestilenzia secondo Maestro Giovanni da Dondoli da Oriolo [Giovanni Dondi Dall'Orologio], il quale compose a richiesta dell'Arcivescovo di Parigi, w: U.G. Becciani, Antologia di brevi testi rari, Il Papyrus Miniedizioni, 2013, <www.ugobecciani.it/libri/antologia.pdf> [dostęp: 10.04.2015]. Tekst Dondiego został napisany po epidemii 1383 r.; zob. także przyp. 107.
} 
niespecjalnie różniące się od kroniki. Rzecz jednak w tym, że w przypadku Dekameronu, jak zresztą $\mathrm{i}$ innych arcydzieł, są to metody niewystarczające, ponieważ jego odczytanie nie mieści się w jednym modelu. W tej sytuacji łatwiej przychodzi historykowi czarnej śmierci i innych pandemii potraktować „Prolog” jak każdy inny kronikarski przekaz, i jako taki — wyjęty z całości dzieła, pozbawiony jego kontekstu - analizować go i wykorzystywać 29 . Tym bardziej że zawarty w nim makabryczny miejscami obraz wypełniają szczegóły z obserwacji, łatwo weryfikowalne w dokumentacji innego typu i w dodatku oficjalnej, wytworzonej przez urzędy.

Tylko w niektórych, z reguły zresztą hermeneutycznych, studiach nad historycznymi źródłami narracyjnymi, niemających na celu ustalenia faktów, rekonstrukcji „rzeczywistości historycznej”, analizuje się ich formę retoryczną i topikę $e^{30}$. Gabriele Zanella, świadom konwencji literackich, miejsca „Prologu” w całości dzieła, podkreśla jednak, że Boccaccio na pytanie o przyczyny zarazy odpowiada „całkowicie konwencjonalnie: w istocie była to manifestacja gniewu Bożego na ludzką niegodziwość" 31 . I dalej starannie wyszukuje, idąc tu przede wszystkim za Vittore Branką, wspólne miejsca z przekazami współczesnymi, odbijającymi identyczną percepcję apokaliptycznej zarazy i sposób jej opisu (plasującymi się wszakże na dużo niższej artystycznie literackiej półce). Podkreśla też zależność nie tylko Boccaccia, ale i kronikarzy od starej tradycji literackiej ${ }^{32}$. Zrekonstruowany przez niego model opisu zarazy, mniej lub bardziej wspólny i powielany, obejmuje: jej bezpośrednie przyczyny, fenomenologię, pochodzenie, sposób roznoszenia się, symptomy choroby, skalę i zasięg geograficzny, cechy choroby, czas trwania, skutki, jakość strat (ludzie znamienici wśród ofiar), bezradność lekarzy, konsekwencje gospodarczo-społeczne, reakcje na zarazę, postawy wobec niej i zachowania. Ostatni element tej struktury opisu — przedsięwzięte środki, G. Zanella omawia jednak w niewielkim stopniu na podstawie źródeł narracyjnych, które albo uwzględniają go marginalnie i selektywnie, albo w ogóle pomijają. Oznacza to przyjęcie oczywistego stanowiska badawczego: żaden z opisów nie przynosi kompletnego obrazu zarazy, rzeczywistości opisywanego miasta czy kraju.

Konstatacja ta dotyczy także trzech najważniejszych narracji florenckich: Boccaccia, Matteo Villaniego i Marchionne. W najobszerniejszej z nich, Villaniego - mimo wielu szczegółów i troski o chronologiczną precyzję (we Florencji zaraza zaczęła się w kwietniu 1348, trwała do początku września, zabiła $3 / 5$ ludności) — nie znajdujemy informacji o podjętych przez władze działaniach zaradczych. W kronice Marchionne dotyczą one organizacji pogrzebów (do czego jeszcze wrócę). Być może, ale to czyste dywagacje, działania władz znalazłyby się w centrum uwagi Giovanniego Villaniego, gdyby przeżył epidemię i kontynuował swoją kronikę, tak jak znalazły się w jego opisie wielkiego głodu 1346/7 r. ${ }^{33}$

Model opisu zrekonstruowany dla przekazów narracyjnych przez Zanellę i - co trzeba podkreślić — zastosowany w tych z nich, które zostały napisane już po ustąpieniu zarazy, odpowiada jedno-

\footnotetext{
${ }^{29}$ Może warto w tym miejscu zauważyć, że historycy literatury bywają z kolei bezradni wobec kontekstu historycznego. Luigi Surdich (a to przykład jeden z wielu), dając w książce Boccaccio, Roma 2001 (Biblioteca Universale Laterza, t. 533) tytuł rozdziałowi „Il Decameron: il tempo storico e le ragioni narrative”, ów tytułowy „,zas historyczny” scharakteryzował na podstawie najbardziej generalizujących, podręcznikowych ujęć.

${ }^{30}$ Znaczący jest tu tytuł międzynarodowej konferencji w Todi w 1993 r. i cyt. wyżej publikacji jej materiałów: La peste nera: dati di una realtà, elementi di una interpretazione.

${ }^{31}$ G. Zanella, Italia, Francia e Germania: una storiografia a confronto, w: La peste nera: dati di una realtà, s. 62 . To przekonanie o gniewie Bożym, jako przyczynie, powtarzane jest aż do XVII w. ,jak mantra”, zob. A.G. Carmichael, Universal and Particular: The Language of Plague, 1348-1500, „Medical History. Supplement”, 27, 2008, s. 17-52, dostępne także: $<$ http://www.ncbi.nlm.nih.gov/pmc/articles/PMC2630032/ > [dostęp: 20.04.2014]. Inaczej jednak interpretuje T. Kircher (The Poet's Wisdom, s. 67 nn.) uważając, że Boccaccio dystansuje się od nauczania Kościoła, zwłaszcza dominikanów, o Bożej roli w ludzkim losie.

${ }^{32}$ G. Zanella, Italia, Francia e Germania, s. 64 n.

33 Giovanni Villani, Nuova Cronica, wyd. G. La Porta, Parma 1991, Lib. XIII, R. LXXIII: „D’uno grande caro che fu in Firenze e d'intorno e in più parti" - ten szczegółowy opis jest chronologicznie uporządkowany, z podaniem ruchu cen podstawowych produktów spożywczych i działań władz co do miesięcy.
} 
cześnie większości kwestionariuszy badawczych dzisiejszych historyków. Jest także jednym ze źródeł schematów interpretacyjnych — toposów nowoczesnej historiografii.

$\mathrm{Z}$ tego modelu wynikają ważne dla historyka wnioski. Źródła narracyjne oferują nam oto obraz zbudowany z dwóch nakładających się na siebie stop-klatek: miasta w momencie kulminacji zarazy oraz po jej ustąpieniu, kiedy ujawnił się w pełni dramat zniszczeń i zmian. Jego ważnym elementem jest typologia zachowań ludzkich w warunkach ekstremalnych — strachu przed niechybną okrutną śmiercią i niewiadomym pochówkiem. W kronikarskim czy literackim opisie zarazy nie ma miejsca na wydarzenia i zjawiska przynależne do zwykłej codzienności, rutyny. Nie ma go też w percepcji zarazy — toposy i przeżyte doświadczenia porządkowane w schematy wyobrażeniowe ostro odcinają kataklizm od normalności. Dane odnoszące się do rzeczywistości zarazy - życia w terroryzowanym przez nią mieście - od ponad stu lat skrupulatnie wydobywane przez historyków z archiwów miejskich, są wobec tego obrazu komplementarne i już choćby z tej racji mogą pełnić rolę weryfikatora „wiarygodności” tekstów literackich i kronikarskich tylko w ograniczonym stopniu. A w przypadku zastosowania tego rodzaju weryfikacji do „Prologu” uwzględnić przecież jeszcze trzeba jego znaczenie w całości dzieła i samą poetykę $e^{34}$. Dorzućmy tu jeszcze, podążając za konstatacjami Kirchera, że dla Boccaccia percepcja zdarzeń historycznych ma wymiar subiektywny: „Prawda [historyczna] z definicji pozostaje obiektywna, podczas gdy stopień jej pojmowania jest subiektywny, zależny zarówno od zmieniających się kryteriów życiowego doświadczenia, zdolności percepcji, jak i okoliczności zewnętrznych"35.

\section{II}

\section{Dokumentacja archiwalna — dynamika zarazy i funkcjonowania wladz}

Jeżeli więc przyjmiemy, że „Prolog”, a także inne przekazy narracyjne ukazują nam odmienny obraz rzeczywistości - inną rzeczywistość lub inny jej wymiar — niż źródła takie jak dokumentacja urzędowa, że oba typy źródeł są przynajmniej w pewnej mierze wobec siebie komplementarne, to możemy zaproponować posłużenie się „Prologiem” Boccaccia jako opowieścią ułatwiającą interpretację owej dokumentacji urzędowej, czyli odwrócić relację między tymi źródłami, którą ustalono i wykorzystywano w dotychczasowych badaniach. Jest to jedna z możliwych metod wydobycia z tych suchych, redagowanych przez notariuszy i zgodnie z formułami notarialnymi tekstów treści dotąd niezauważonych, a stanowiących materiał do słabo do niedawna eksplorowanej percepcji zarazy. W ostatnich latach zdziałali na tym polu więcej historycy sztuki niż historycy ${ }^{36}$.

W dokumentacji władz i magistratur florenckich, zwłaszcza tej jej części, która do tej pory była w niewielkim stopniu wykorzystana, poszukiwać najpierw będziemy dynamiki szerzenia się zarazy, zwracając baczną uwagę na moment jej kulminacji. Zajmiemy się następnie najwcześniejszymi śladami tej powszechnej percepcji dżumy i świadomości jej niszczycielskiej siły, którą wyczytano w „Prologu”, w kontynuacji Matteo Villaniego i w kronice Marchionne, a także śladami owych „diverse paure e immaginazioni in quegli che rimanevano vivi”, które „nacquero dalle quali cose e da assai altre a queste simiglianti o maggiori”. Dokumentacja „oficjalna”, wspomożona wypowiedziami

\footnotetext{
${ }^{34}$ G. Mazzotta (The World at Play, s. 20) szczególną uwagę zwraca na hipotaktyczną aranżację zdań, bogactwo zdań podporządkowanych i zamierzony powolny rytm, które są świadectwem intelektualnego wysiłku, by rozczłonkowane zjawiska świata poskładać w zrozumiały model porządku i hierarchii.

35 T. Kircher, The Poet's Wisdom, s. 50.

${ }^{36}$ Czytelnika chciałabym odesłać przede wszystkim do dwóch artykułów: L. Marshall, Manipulating the Sacred: Image and Plague in Renaissance Italy, ,Renaissance Quarterly”, 47, 1994, nr 3, s. 485-532 (dotyczy głównie lat późniejszych, po czarnej śmierci 1348 r.) oraz A. Zorzi, L'angoscia delle repubbliche. Il „timor” nell'Italia comunale degli anni trenta del Trecento, w: The Languages of Political Society: Western Europe, 14th-17th Centuries, red. A. Gamberini, J.-P. Genet, A. Zorzi, Roma 2011, s. 287-324, <https://lamop.univ-aris1.fr/IMG/pdf/The_languages_of_political_society.pdf> [dostęp: 01.10.2014], który z kolei dotyczy lat poprzedzających czarną śmierć (tekst dostępny w Internecie także w języku angielskim).
} 
osobistymi obywateli florenckich, a więc testamentami i księgami rodzinnymi, pozwala na sporządzenie paralelnej do tej, którą znajdujemy w źródłach narracyjnych, typologii zachowań. Chodzi nam zwłaszcza o uchwycenie zachowań „normalnych”, na które nie ma miejsca w opisie sytuacji niemieszczącej się w żadnej „normie”. Na boku pozostawimy jednak jej psychologiczną interpretację, do której klucz znajduje się z reguły poza dokumentacją urzędową, a w przypadku wypowiedzi osobistych (ricordanze, listy) wymaga ona analizy znacznej szerszej niż pozwalają na to rozmiary nawet obszernego artykułu.

Zacząć należy naszą analizę od ważnej, a prawie nie branej pod uwagę obserwacji dotyczącej zasadniczej różnicy między narracją Boccaccia i większości przekazów kronikarskich a dokumentacją archiwalną: obraz zarazy w tych pierwszych tekstach nie jest dynamiczny i zmienny. Zaraza dociera do miasta, trwa 5-6 miesięcy, wycofuje się, ale jej niszczycielska siła nie narasta, a potem nie cofa się ustępując życiu powracającemu w swoje koleiny. Jest ukazana niemal wyłącznie w swoim apogeum i poprzez żniwo, które zebrała. Tymczasem w źródłach, które mają „weryfikować” ten obraz, obserwujemy kolejne etapy jej szerzenia się i przebiegu. W połowie czerwca, w trzecim miesiącu jej panowania, dzienne zejścia obliczano już na 100, w lipcu i sierpniu — miesiącach najbardziej tragicznych - 300, 380, 400 37. Na przełomie sierpnia i września dżuma zaczęła się szybko wycofywać, choć zachorowania zdarzały się jeszcze późną jesienią. Mimo więc iż od jesieni 1347 r. wiedziano o wybuchu wielkiej i niespotykanej dotąd śmiertelności, śledzono jej szerzenie się w kolejnych regionach i szybkie zbliżanie się do Florencji, jej pojawienie się tu i pierwsze tygodnie zarazy nie musiały sprawiać wrażenia apokaliptycznej katastrofy.

Co więcej, dżuma nie spadła na miasto w okresie jego prosperity, miasto zbierające obfity plon długiego, niczym niezakłóconego rozwoju. Była kolejną w ciągu plag (zresztą, nie tylko we Florencji), które niosły ze sobą masową śmiertelność i odciskały piętno na społecznym ładzie. Umierający na dżumę w 1348 roku kronikarz Giovanni Villani odwrócenie losów Florencji dostrzegł już w wielkiej, katastrofalnej powodzi 1333 r.; w 1340 r. spadła na miasto zaraza (prawdopodobnie tyfus), 1343 głód, 1346-1347 wielki głód, który pochłonął co najmniej kilka tysięcy istnień ludzkich (być może nawet 15 tys.). Po niezłych zbiorach w lecie 1347 r., zażegnaniu zagrożenia dalszym brakiem żywności i horrendalnymi cenami zboża i w ogóle żywności, władze miejskie i jego mieszkańcy zmagali się ze skutkami ponadrocznego jej dramatycznego niedostatku: masą niespłaconych długów, plagą kradzieży, gigantycznymi defraudacjami, a także epidemią, prawdopodobnie tyfusu.

Powolny rytm wychodzenia z kryzysu widać dobrze za murami więzienia komunalnego, Stinche. Z przetrzebionego archiwum więziennego przetrwał do naszych czasów rejestr więźniów prowadzony przez obejmujących swoją funkcję 1 października 1347 r. nowych zarządców, soprastanti alle Stinche (ich kadencja trwała do końca marca 1348) ${ }^{38}$. W całym półroczu osadzono w Stinkach 1014 osób (1 października uwięzionych było 315 osób) — ok. 65\% za długi i inne zobowiązania finansowe (w poszczególnych miesiącach od 35 do 98 \%). Gdy tylko bowiem w sierpniu 1347 r. straciło moc prawo ograniczające więzienie za długi do zobowiązań powyżej 100 florenów — wprowadzone dla zapobieżenia masowej śmiertelności w Stinche - cechy, magistratury i prywatni wierzyciele ruszyli tłumnie do trybunału podesty po pozwolenie na osadzenie w więzieniu swoich dłużników. Jeszcze w styczniu 1348 r. na 189 osób zamkniętych w Stinche tylko 5 trafiło tam nie za zobowiązania płatnicze. W lutym, kiedy epidemia szalała już w Pizie, wezbrana fala więzienia dłużników opadła. Zamknięto wprawdzie jeszcze więcej osób - 226, ale „tylko” 108 za długi (52\%). Możemy też stwier-

\footnotetext{
37 A. Carmichael, Plague Legislation in the Italian Renaissance, „Bulletin of the History of Medicine”, 57, 1983 , s. 514. W październiku np. znajdujemy nadal informacje o wyjazdach (ucieczkach) z miasta. Te liczby trzeba traktować jako „dające wyobrażenie”. W Orvieto miałoby tych zejść dziennych być nawet 500, zob. E. Carpentier, Une ville devant la peste, s. 120. Pierwsze dokładne dane dla Florencji dotyczą epidemii 1400 r. (ponad 12 tys. ofiar): w czerwcu pogrzebano 2697 osób, w lipcu - 5005, w sierpniu - 1947, zob. S.K. Cohn, The Black Death, s. 725.

38 Archivio di Stato di Firenze [dalej: ASF], Soprastanti alle Sinche, 82.
} 
dzić, że do końca marca śmiertelność wśród więźniów była relatywnie niska ${ }^{39}$, co obok innych danych wskazuje, że, tak jak pisał Matteo Villani, a wbrew innym przekazom (w tym Boccaccia) i większości badaczy, dżuma zaatakowała mieszkańców Florencji w kwietniu.

W tygodniach poprzedzających jej nadejście mieszkańcy wprawdzie nie zapomnieli jeszcze codziennej obecności śmierci na ulicach miasta, chowania zmarłych bez należytego ceremoniału, w masowych grobach, ale życie powoli wracało do stanu normalnego ${ }^{40}$, skoro zdarzyło się zamknięcie w więzieniu własnego syna (na prośbę ojca, zalecane jako ekstremalna forma dyscyplinowania krnąbrnego potomka). Przeplatanie się pesymizmu płynącego z minionych i zbliżających się klęsk naturalnych z nadzieją na powrót dobrych czasów dobrze oddają ostatnie rozdziały Nowej Kroniki. Giovanni Villani pisze w nich o tragicznych trzęsieniach ziemi na przełomie 1347 i $1348 \mathrm{r}$. we Włoszech i Niemczech i dzieli się z czytelnikiem przeczuciem zbliżającego się końca świata ${ }^{41}$. Ale ostatnie fragmenty dotyczące Florencji — o skutecznym zahamowaniu przez Ufficiali del biado gwałtownego na przełomie listopada i grudnia 1347 wzrostu cen zboża i o powrocie do dawnego, sprzed rządów „tyrana”, Waltera z Brienne (1342/3), terminarza wyborów i obsady głównych urzędów policyjno-sądowych sprawowanych przez „cudzoziemców” (ufficiali forestieri) w półrocznej kadencji (podesta, kapitan ludu, egzekutor sprawiedliwości, sędzia apelacji) — choć podszyte nutką pesymizmu ${ }^{42}$ zdradzają wiarę w dobre rządy i ład komunalny.

W trudnej sytuacji wychodzenia z kryzysu po wielkim głodzie ciągłość i skuteczność władzy w newralgicznej sferze porządku, bezpieczeństwa i sądownictwa zapewnić miało powołanie na przełomie 1347 i 1348 r. na drugą kadencję sprawdzonych już w działaniu urzędników. Po ustaniu zarazy, w końcu 1348 r. powtórzono częściowo ten manewr i powołano na drugą kadencję kapitana ludu, a w 1349 r. urzędujący od 1 grudnia 1348 r. do końca maja roku następnego podesta Bonifacio de' Ranieri z Orvieto został wybrany na urząd kapitana ludu poczynając od 1 sierpnia. W obu okresach: przełomu 1347 i 1348 r. oraz rok później trybunały sądowe, którym ci urzędnicy przewodzili, zawalone były rosnącą liczbą spraw, głównie cywilnych; trudnym zadaniem było utrzymanie bezpieczeństwa, a także skuteczne ukaranie wszystkich urzędników i funkcjonariuszy, którzy wykorzystali kryzysową sytuację do wzbogacenia się defraudując pieniądze komunalne (w czasie wielkiego głodu kilku emptores gabellae vini sprzeniewierzyć miało astronomiczną kwotę 11 tys. florenów) ${ }^{43}$. W końcu marca priorzy cechów (florencki „rząd”) podjęli decyzję o wzmocnieniu straży nocnych (sprawowali ją mężczyźni z niższych warstw społecznych) i własnej nad nimi kontroli, ponieważ m.in. w związku ze wzrostem liczby kradzieży i zuchwałością złodziei — pojawili się strażnicy opłacani przez prywatnych obywateli, którzy sami zaczęli zagrażać bezpieczeństwu i mieniu ludności: „ita quod multi tales custodes per singularibus positi non timentes vadunt et dicurrunt per terram

\footnotetext{
${ }^{39}$ Z 470 osób osadzonych od października do końca grudnia zmarło w więzieniu za kadencji tych zarządców 21 (385 zostało zwolnionych).

${ }^{40}$ ASF, Atti del Podestà [dalej: AP] 276, f. 133v — osadzenie w więzieniu syna za bliżej nieznane przewiny. Prywatna petycja kosztowała niemało - 25£, a do tego dochodziły koszty utrzymania takiego „prywatnego” więźnia.

${ }^{41}$ Giovanni Villani, Nuova Cronica, Lib. XIII, R. CXXII i CXXIII. Kronikę kończy zadanie: „E nota, lettore, che·lle sopradette rovine e pericoli di tremuoti sono grandi segni e giudici di Dio, e non sanza gran cagione e premessione divina, e di quelli miracoli e segni che Gesù Cristo vangelizzando predisse a' suoi discepoli che dovieno apparire alla fine del secolo". 42 Tamże, R. CXVIII. Chwaląc decyzję o przywróceniu dawnych terminów obsady urzędu podesty, kapitana ludu i egzekutora aprawiedliwości: „che·ffu buono e ottimo dicreto, quando s'osservasse”, zaraz dodaje za Dantem [Pg VI, 143]: „Ma il nostro difetto di mutare spesso leggi e ordini e costumi col non istante che'ssi mette nelle riformagioni del Comune guasta ogni buono ordine e legge, ma èssi nostro difetto quasi naturato «[...] che in mezzo novembre/ Non giugne quel che·ttu d'ottobre fili» come disse il nostro poeta."

${ }^{43}$ Głównym naszym informatorem jest niezawodny Giovanni Villani. Sam proces zob. ASF, AP 276, f. 83r-83v Wyrok wydano także na ich poręczycieli. Plagę kradzieży (bardzo często zboża), zwłaszcza w czasie i po wielkim głodzie, widać w aktach kryminalnych podesty i kapitana ludu, a także w ASF, Atti del Capitano del popolo e difensore delle arti [dalej: AC] 69 - Liber tamburagionum za okres luty - maj 1348, gdzie wśród anonimowych donosów (owych tamburagioni) ciągle jeszcze zdarza się denuncjowanie kradzieży zboża.
} 
partim ut de die et multa inhonesta et illicita comictentes contra honorem nostri offitii et regiminem civitatis (...)"44.

Historycy, którzy przeciwstawiają obraz wyłaniający się z dokumentacji florenckich magistratur akcentowanemu przez kronikarzy i Boccaccia chaosowi ${ }^{45}$, powołują się przede wszystkim na zachowanie ciągłości władzy, szczególnie trudne w ustroju komunalnym takich republik miejskich jak Florencja, gdzie kadencja najwyższej władzy - Signorii (chorąży sprawiedliwości i 8 priorów cechów) trwała dwa miesiące i nie mogła być przedłużona, a trybunałów (ufficiali forestieri) sześć miesięcy i zmiana na tych ostatnich urzędach przypadła na apogeum zarazy, między końcem maja a końcem lipca. Zauważają wprawdzie dłuższą przerwę w zwoływaniu rad (Podesty/Komuny i Kapitana ludu/ Ludu) ${ }^{46}$, oraz nieobecność licznych urzędników i funkcjonariuszy (w tym wśród tak ważnych kolegiów, jak 16 Chorążych kompanii ludowych i 12 Dobrych Mężów [Buoni Uomini]) ${ }^{47}$, a także wyrwę w dokumentacji cechowej, ale zachowane Deliberazioni dei Signori e Collegi potwierdzają nieprzerwane funkcjonowanie najwyższych władz nawet w okresie apogeum zarazy i rutynową współpracę między różnymi magistraturami. W połowie lipca priorzy cechów pisali do podesty, by wezwał mieszkańców do przeciwdziałania skutkom masowej śmiertelności i ucieczki: mają zabezpieczyć opuszczone domy, dbać, by ulice i zaułki nie pokryły „fastidia, putridia, bructure”, które łatwo powodują corruptio aeris ${ }^{48}$.

Obraz funkcjonowania władz nie jest jednak tak jednoznaczny, jak chcieliby niektórzy historycy. Na lutowych i marcowych posiedzeniach obu rad florenckich: Podesty i Kapitana ludu nie odnotowano jeszcze większych nieobecności: na posiedzeniach tej pierwszej uczestniczyło od 205 do 229 radnych, tej drugiej 204-209. Jeszcze w końcu marca wzięło udział w głosowaniu 202 członków Rady Podesty ${ }^{49}$. Jednak od 11 kwietnia aż do 23 sierpnia brakuje protokołów z ich posiedzeń. Wbrew jednak odwołującej się do tego braku konstatacji Alberto B. Falsiniego ${ }^{50}$, nie zaprzestano ich zwoływania. Na posiedzeniach obu rad, kolejno 18 i 19 lipca, nieobecnych było ponad 50 radnych każdej z nich, mimo - jak można przypuszczać - wyjątkowej mobilizacji ${ }^{51}$. Należy raczej zakładać, że zbierały się nieregularnie i znacznie rzadziej. Zgodnie też z nakazanym przez prawo rytmem kadencji, w drugiej połowie maja - choć z trudem i koniecznością dokonania licznych korekt (niektórzy kandydaci zmarli, inni uciekli z miasta) - przeprowadzono wybory do obu rad. W połowie września na posiedzenie Rady Podesty stawiło się 148 jej członków. W następnych miesiącach, aż do grudnia,

\footnotetext{
${ }_{44}$ ASF, Provvisioni Registri [dalej: Prov. Reg.] 35, f. 119v (27 III 1348). Zob. też U. Dorini, Il diritto penale e la delinquenza in Firenze nel sec. XIV, Lucca 1923, s. 247. Straż nocną w mieście w określonych miejscach pełnili wyznaczeni do tego mężczyźni; były też straże cechowe oraz patrole wykonywane przez aparat policyjny podesty, kapitana ludu i egzekutora sprawiedliwości; zob. H. Manikowska, Nadzór i represja. Władza i społeczeństwo w późnośredniowiecznej Florencji, Warszawa 1993, s. 198-218.

45 „Prolog”: „E in tanta afflizione e miseria della nostra città era la reverenda autorità delle leggi, così divine come umane, quasi caduta e dissoluta tutta per li ministri e esecutori di quelle, li quali, sì come gli altri uomini, erano tutti o morti o infermi o sì di famigli rimasi stremi, che uficio alcuno non potean fare; per la qual cosa era a ciascun licito quanto a grado gli era d'adoperare".

${ }^{46}$ Także w innych miastach, np. w Sienie - od czerwca do połowy sierpnia, zob. W. Bowsky, The Impact, s. 14; o Bolonii zob. S.K. Wray, Communities and Crisis, s. $149 \mathrm{nn}$.

${ }^{47}$ F. Carabellese, La peste nera, s. 54. Nieobecność (starano się ustalić, czy jej przyczyną nie była choroba lub śmierć) była karana grzywną (tu: 100 £), stąd łatwo stwierdzić, że zarówno odbywały się kontrole, jak i kto został ukarany (appuntato). 48 ASF, AP 372, f. 39.

49 ASF, Libri fabarum (dalej: LF) 28, f. 104r-104v, 107r-107v, 112r-112v, 114v-115r. W księgach tych znajdują się protokoły z posiedzeń Rad, głosujących nad rozporządzeniami władz (głosowano ziarnami bobu, fabae); ostatnie zanotowane posiedzenie miało miejsce 28 marca. W następnej księdze, LF 29, pierwsze posiedzenie - 12 września. O posiedzeniach Rad informację przynoszą także Provvisioni (serie: Registri, Duplicati, Protocolli), np. w postaci dopisku o liczbie głosów, jaką oddano za i przeciw przyjętemu rozporządzeniu władz.

50 A.B. Falsini, Firenze dopo il 1348, s. 438; zauważa jednak, że są jakieś deliberazioni.

51 J.M. Najemy, Corporartism and Consensus in Florentine Electoral Politics 1280-1400, Chapel Hill 1982, s. 158 n., przyp. 66 - liczba obecnych: 153 i 152. O wadze tego posiedzenia zobacz niżej.
} 
na Radzie Kapitana ludu głosowało 120-126 radnych, na Radzie Podesty 105-13952. Rosnacca liczba ofiar i uciekinierów wśród różnej rangi urzędników i funkcjonariuszy komuny zmusiła władze do ich poszukiwania i nakładania kar pieniężnych na tych, których uznano za „zbiegów” — zgodnie z prawem i procedurą appuntare, czyli zanotowania kogoś, kto nie wypełniał swoich obowiązków urzędnika/funkcjonariusza ${ }^{53}$.

Zachowana dokumentacja głównych magistratur sądowo-policyjnych bodaj najlepiej odzwierciedla dwie płaszczyzny działalności urzędników i funkcjonariuszy władz komunalnych: podporządkowanie prawu i wynikającym z niego procedurom, konieczne m.in. by sindacato (kontrola po zakończeniu urzędowania) przebiegło pomyślnie, oraz faktyczną egzekucję uprawnień i obowiązków, jej skuteczność. W tej pierwszej mieści się sposób prowadzenia księgi, wedle formularza zgodnego właśnie z tymi procedurami, który może sprawiać wrażenie nieprzerwanej i skutecznej działalności ${ }^{54}$.

Analiza tej drugiej płaszczyzny wskazuje natomiast wyraźnie na postępujący aż do zamarcia spadek aktywności wielu magistratur. Raporty z patrolowania ulic miasta (tzw. cerca ordinaria) przez oddziały egzekutora sprawiedliwości (Esecutore degli Ordinamenti di giustizia) za dnia i po trzecim dzwonie oddają znakomicie słabnący rytm funkcjonowania urzędu. Zawarte są one w starannie prowadzonej księdze (wpisy rozpoczynają się od momentu rozpoczęcia nowej kadencji, 15 I 1348 r.). Dzień po dniu, aż do końca maja odnotowywano w niej zatrzymane osoby (lub ich brak), z informacją o rodzaju złamanego przepisu (niedozwolone noszenie broni, niedozwolony hazard, nieprzestrzeganie godziny policyjnej) $)^{55}$. W czerwcu notariusz zapełnił karty księgi niemal wyłącznie (zob. niżej) formularzowym wpisem dat dziennych. Oddziały tego egzekutora sprawiedliwości można ocenić jako przeciętnie zaangażowane w nocne i dzienne patrolowanie ulic ${ }^{56}$. W drugiej połowie stycznia, a więc w pierwszych tygodniach nowej kadencji, przy siedmiu datach dziennych figurują wpisy o skutecznym patrolu (w sumie nałożono grzywny na 27 osób, w tym 18 za poruszanie się bez wymaganego światła po trzecim dzwonie [coprifuoco]). W lutym (rok był przestępny), miesiącu karnawału (Środa Popielcowa wypadła 5 marca), wyraźnie słabiej kontrolowano miasto - adnotacje o grzywnach znajdują się tylko przy jedenastu datach, złapano na łamaniu przepisów 27 osób (w tym 10 „hazardzistów”). W marcu i pierwszych dwóch tygodniach kwietnia (do 13.), czyli w okresie

\footnotetext{
52 ASF, LF 29, passim. 21 listopada wymierzono 41 członkom Rady Podesty (po 10 z trzech dzielnic i 11 z dzielnicy San Giovanni) grzywny za ich nieobecność (ASF, AP 337, f. 95). Niewystarczająca liczba obecnych na posiedzeniach radnych była poważnym problemem prawno-proceduralnym, czemu daje wyraz rozporządzenie z 18 IX 1348 r., Prov. Reg. 36, f. 10: „considerantes et advertentes, quod difficulter et cum magno tedio consilium domini Potestatis et Communis Florentie in opportuno numero propter absentiam multorum civium congregari potest et nolentes propterea negotia, que emergunt cum dispendio retardari...”. Donato Velluti, patrycjusz florencki, autor świetnej księgi rodzinnej (Cronica domestica di messer Donato Velluti scritta fra il 1367 e il 1370, wyd. I. Del Lungo, G. Volpi, Firenze 1914), pisze, że już po ustaniu epidemii przy obsadzie urzędów na ostatnim etapie procesu wyborczego, którym było losowanie (tratte) spośród kandydatów, którzy przeszli wcześniej pomyślnie procedurę wyborczą, trzeba było najpierw otworzyć i sprawdzić worki, z których losowano kartki z nazwiskami, by wykluczyć zmarłych (s. 192 n.). Więcej o funkcjonowaniu poszczególnych magistratur, A.B. Falsini Firenze dopo il 1348, s. 438 n.

${ }^{53}$ Zob. ASF, AP 334, f. 5 - gdzie grzywny (po 100 ) nałożone w czerwcu na urzędników szukanych przez podestę i uznanych za uciekinierów (11 [na 16] chorążych kompanii ludowych, połowa z dwunastoosobowego kolegium Dobrych Mężów, 4 skarbników [camarlinghi] komuny, dwóch urzędników della Condotta, 9 z 12 urzędników della Moneta); AP 372 — gdzie także inne interwencje priorów cechów u podesty i sędziego fiskalnego (giudice di gabelle e camera). Rękopisy te dają przy okazji wyobrażenie o śmiertelności wśród urzędników i funkcjonariuszy komuny. Por. także F. Carabellese, La peste nera, s. 34.

${ }^{54}$ Por. np. ASF, Atti dell' Esecutore degli Ordinamenti di Giustizia [dalej: AEG] 103, gdzie znajdują się zapisy m.in. o regularnych comiesięcznych bannimenta per loca solita; o cotygodniowych, a w końcówce urzędowania, czyli już w okresie bardzo wysokiej śmiertelności, przeprowadzanych co dwa tygodnie śledztwach (inquisitiones) w więzieniu komunalnym; o odebraniu przysięgi od woźnych (nuntii) komuny itd.

${ }_{55}$ ASF, AEG 100. Dokumentacja zawierająca raporty z cerca ordinaria, także innych trybunałów (podesty, kapitana ludu) miała charakter przede wszystkim fiskalny. Służyła do rozliczenia się z nałożonych bez postępowania sądowego grzywien (mandatów) z camera del comune. Jeśli złapany nie zapłacił jej od razu, był odprowadzany do więzienie komunalnego.

56 Zob. szerzej na ten temat: H. Manikowska, Nadzór i represja, s. 213 nn., passim.
} 
Wielkiego Postu (Wielkanoc wypadła 20 kwietnia) patrole były najskuteczniejsze — przy 27 datach dziennych (19 marcowych) zapisano naruszenia prawa. Złapano na nich 79 osób (67 za poruszanie się bez światła po oddzwonieniu ,godziny policyjnej”). Zobaczymy niżej, że w tym właśnie okresie skutecznie też inwigilowano naruszenia ustawodawstwa antyzbytkowego (leges sumptuariae). W Wielkim Tygodniu i oktawie Wielkiej Nocy, poza formularzowym zapisem w księdze o odbytej kontroli, ślady patrolowania miasta są niemal niewidoczne (w Wielką Środę zatrzymano jednego bez światła). W maju cerca ordinaria jeszcze miała miejsce (7 dat $\mathrm{z}$ odnotowanymi wykroczeniami), w czerwcu jedynie 25, a więc w czasie obchodów święta patronalnego, przyłapano dwie osoby bez światła. Raporty z kontroli miasta przez oddziały następnego egzekutora sprawiedliwości potwierdzają już tylko jej zaniechanie bądź sprawowanie jej niezgodnie z prawem i obowiązującymi procedurami ${ }^{57}$.

Do obowiązków patroli egzekutora sprawiedliwości należała też inwigilacja miasta w celu wykrycia i ukarania wykroczeń przeciwko ustawodawstwu antyzbytkowemu ${ }^{58}$. Ta część egzekucji prawa należy do najsłabiej udokumentowanych, co większość badaczy uznaje za jeszcze jeden dowód na niefunkcjonowanie leges sumptuariae, nie tylko zresztą w miastach włoskich (martwe prawo) ${ }^{59}$. Tym ciekawsze są więc sprawy, które wytoczył za ich przekraczanie egzekutor sprawiedliwości w czasie, gdy zaraza docierała już do bram Florencji. Składają się na nie dwa typy wykroczeń: zbyt liczne, przekraczające dozwoloną liczbę 50 mężczyzn zgromadzenia weselne, organizowane przez panów młodych (raunata matrimonii causa) oraz noszenie przez kobiety niedozwolonej biżuterii i szat. W tym pierwszym przypadku egzekutor wysunął kilkanaście oskarżeń dotyczących zgromadzeń przed kościołami florenckimi (rzadziej przed domem prywatnym nowożeńca), z których większość miała miejsce w okresie Wielkiego Postu ${ }^{60}$. Być może na skrupulatność egzekucji prawa, które, gdy je wprowadzano, dyktował strach przed konsekwencjami dla ładu politycznego i spokoju w mieście zbyt licznych zgromadzeń mężczyzn należących do najwyższych warstw społecznych i z reguły tego samego stronnictwa (fazione), wpłynęły tym razem także względy związane z szerzeniem się już zarazy. 2 kwietnia bowiem, a więc tydzień po pierwszych odnotowanych w aktach egzekutora w związku z tymi zgromadzeniami oskarżeniach, władze florenckie podjęły pierwsze ważne decyzje dotyczące epidemii: powołano ośmiu offitiales super purgatione et mundatione civitatis $^{61}$. W ostatnich tygodniach karnawału (przełom lutego i marca) patrole egzekutora odniosły sukcesy w ściganiu patrycjuszek paradujących z wykonanymi z kruszcu opaskami na głowach (cerchietti). W pierwszej połowie kwietnia natomiast (Wielki Post) ofiarami kontroli padły kobiety odziane w wierzchnie szaty (guarnacchie) ze zbyt długimi rękawami ${ }^{62}$. Dodajmy już tylko dla pełniejszego obrazu kontroli mia-

\footnotetext{
57 ASF, AEG 109. Nie można wykluczyć, że nakładane na złapanych na tych wykroczeniach grzywny familia zagarniała dla siebie. W całym zeszycie wpisane są jedynie daty sierpniowe od 1. do 9. Przy tej ostatniej dacie wpisano osobę przyłapaną na niezgodnym z prawem noszeniu noża.

${ }^{58}$ Egzekucją tej części prawa florenckiego zajmowały się w różnych okresach różne magistratury, bywał także powoływany specjalny urzędnik (zawsze jednak należał on do tzw. ufficiali forestieri). Do obowiązków egzekutora sprawiedliwości należała ona w latach 1345-1356. Ostatnio o tym G. Biscione, L'ufficiale delle donne, degli ornamenti e delle vesti. Profilo istituzionale e vicende archivistiche, w: Draghi rossi e querce azzurre. Elenchi descrittivi di abiti di lusso (Firenze 13431345), red. L. Gérard-Marchant, Firenze 2013, s. LXXV-CII.

${ }_{59}$ Szerzej o tym zob. H. Manikowska, Nadzór i represja, s. 248-260. Najstarsza florencka dokumentacja sądowa, podobnie jak wielu innych magistratur, spłonęła w czasie rewolty w $1343 \mathrm{r}$.

${ }_{60}$ ASF, AEG 103, f. 108 - 27 marca, oskarżono pięciu organizatorów tego rodzaju zgromadzeń; f. 110 i 112 - 7 kwietnia, 5 oskarżonych (w tym jedna wdowa; jeden dysponował stosownym pozwoleniem); f. $117-9$ maja, 10 osób w związku z dwoma zgromadzeniami w kwietniu; f. 118 - 10 maja, w dwóch sprawach 10 osób. Organizatorem jednego z tych ostatnich zgromadzeń był Salvestro Manni (Alemanni) dei Medici. Zawarcie przezeń małżeństwa z Bartolmeą Altoiti datuje się niepewnie na rok 1349 (G. Brucker, The Medici in the Fourteenth Century, „Speculum”, 32, 1957, nr 1, s. 7); z tej noty wynika, że było to rok wcześniej lub chodzi o zaręczyny. W obu wypadkach — oficjalnych zaręczyn i zawarcia małżeństwa - obowiązały te same ograniczenia.

${ }^{61}$ ASF, Prov. Reg. 35, c. $133 \mathrm{v}$.

62 ASF, AEG 103, f. 103-105, 111, 115.
} 
sta w okresie karnawału i Wielkiego Postu 1348 r., że z wyraźnym zapałem ścigano również zorganizowany, pozauliczny hazard i nielegalne szulernie ${ }^{63}$.

Analogiczne raporty z inwigilacji miasta przez familię kapitana ludu Paolo di Negro Brusati z Brescii świadczą, że trybunał ten wywiązywał się z obowiązków patrolowania miasta tylko na samym początku drugiej kadencji tego urzędnika (od 1 lutego). Poważnym sukcesem było wówczas aresztowanie dwóch mężczyzn skazanych zaocznie na śmierć przez podestów urzędujących w latach 1346 i 1347 oraz dwóch innych banitów (skazani przez podestów z lat 1343/4 i 1344/5) ${ }^{64}$. W lutym prowadzący księgę raportów notariusz nie zanotował żadnych przekroczeń przepisów policyjnych przy 10 datach dziennych; w marcu przy 21 datach, w kwietniu przy 18 . W maju tylko przy trzech datach wpisano ukaranych grzywną i ich wykroczenia. Księga urywa się 16 maja $^{65}$.

O ile jednak obraz patrolowania miasta, jego wyraźnie słabnącego rytmu wraz z narastaniem epidemii nie jest bardzo specyficzny — także w innych latach wielu „urzędników cudzoziemskich” i podległych im oddziałów policyjnych zaniedbywało zwłaszcza przy końcu kadencji swoje obowiązki (lub defraudowało grzywny, nie odnotowując przyłapanych na wykroczeniach) — o tyle akta toczących się w trybunałach florenckich spraw sądowych, obejmujące miesiące apogeum zarazy (lipiec — sierpień), są uderzająco „cienkie”. Wpływ na to miała z pewnością nieregularność rzadko zwoływanych posiedzeń. Spadek częstotliwości ogłaszania wyroków w sprawach karnych w trybunale podesty zaczął się już w maju, skoro w kwietniu orzekano w czasie ośmiu dni (mimo Wielkiego Tygodnia i Oktawy Wielkiej Nocy), a w maju już tylko pięciu. W czerwcu sędziowie podesty ogłaszali wyroki (wszystkie w sprawach rozpoczętych jeszcze przez trybunał poprzednika) jeszcze z normalną, choć bliższą przewidzianemu prawem minimum, częstotliwością — w każdą sobotę miesiąca. W lipcu funkcjonowanie trybunału wyraźnie się załamało: wyroki wydano tylko 10 lipca (czwartek); w sierpniu orzeczenia zapadły 7. i 23. tylko w pięciu sprawach; wszystkie dotyczyły okradania domów! ${ }^{16}$ We wrześniu liczba posiedzeń i spraw gwałtownie wzrosła - na posiedzeniach w trakcie 6 dni (w tym znowu we wszystkie soboty) wydano wyroki w 41 sprawach karnych, w październiku w ciągu 12 dni — 98 wyroków. Dopiero w listopadzie i grudniu powrócił rytm cotygodniowego osądzania spraw karnych. Wyraźne jest też zaostrzenie egzekucji kar, nawet relatywnie niewysokie grzywny $25 £$ musiały być zapłacone w ciągu 10 dni pod rygorem amputacji dłoni. Ale ta niska częstotliwość pracy w czasie apogeum zarazy najważniejszego i największego trybunału sądowego spowodowana była także zewnętrznymi przyczynami. W sprawach karnych jedną z ważniejszych przyczyn był stopniowy zanik aktywności tzw. cappellani laici florenckich parafii (popoli), zobowiązanych do notyfikacji sprawców zabójstw, napadów i bójek. Niektóre oparte na podstawowych strukturach społeczno-administracyjnych zasady funkcjonowania tego społeczeństwa, a zwłaszcza jego aparatu ścigania, uległy erozji i nawet po cofnięciu się zarazy powrót do nich nie był już możliwy. Jeszcze w przededniu epidemii, między grudniem $1347 \mathrm{r}$. a lutym roku następnego, na 106 zakończonych wyrokiem podesty procesów o napaść i bójkę, do których doszło na terenie miasta, 62 rozpoczęto na skutek doniesienia owych „świeckich kapelanów” lub w wyniku zawiadomienia egzekutora sprawiedliwości (na podstawie anonimowych donosów, tzw. tamburagioni). W kwietniu i maju na 43 osądzone akty pobicia i zranienia, 18 zgłosili cappellani laici,

\footnotetext{
${ }^{63}$ ASF, AP 278, f. 27v, 87, 101v, passim. W jednym z procesów (o prowadzenie szulerni i grę, w dodatku fałszowanymi kośćmi), oskarżonych był dwóch Frescobaldich, Stoldo i Angelo; w wyroku ich uniewinniono.

${ }^{64}$ ASF, AC 68.

${ }^{65}$ F. Carabellese, La peste nera, s. 61 przytacza zapisy świadczące o tym, że Paolo di Negro został odwołany z urzędu 22 maja (co zdarzało się niezwykle rzadko). Rzeczywiście, w niektórych aktach oznaczonych jako należące do jego magistratury, znajdują się wpisy lipcowe sporządzone przez notariuszy jego następcy, Niccolò (lub Nicola) di Ranuccio della Serra z Gubbio. Poszczególne poszyty akt magistratury tego ostatniego (AC 70-105), zaczynają się w przeważającej części dopiero jednak w sierpniu. Najwcześniejsza jest księga dochodzeń (Inquisitiones) — pierwsze zapisy datowane są tu na 22 lipca.

${ }^{66} \mathrm{Na}$ podstawie ksiąg wyroków (condempnationes, sentenze) podestów Quirico di Cardulo (ASF, AP 279) i Salamone d. Monaldi z Bettony: ASF, AP 334-337.
} 
natomiast między czerwcem a grudniem na 64 już tylko $14^{67}$. W drugiej połowie stulecia to ważne ogniwo w informowaniu sądów o dokonanych na terenie miasta przestępstwach znika ze źródeł.

W okresie apogeum zarazy z dnia na dzień gwałtownie ubywało spraw wnoszonych do sądów. Dobrym materiałem źródłowym do analizy są akta pozostawione przez magistraturę kapitana ludu, późniejszego wybitnego dowódcę oddziałów najemnych (capitano di ventura) Nicola di Ranuccio Della Serra z Gubbio, ponieważ sprawował on swój urząd przez dwie kadencje, od lata 1348 r. do lata 1349 r. Nie był to jego pierwszy wysoki urząd we Florencji. Miał już za sobą jedną kadencję podesty (1335), wcześniej był także podestą w Sienie. Widać wyraźnie, że władze powołując w tym trudnym czasie sprawdzonych ,zawodowców” starały się zapewnić komunie przede wszystkim bezpieczeństwo i skuteczną egzekucję prawa. Wedle kalendarza obsady urzędów, powinien był objąć swój urząd 1 sierpnia; drugą kadencję rozpoczął 1 lutego 1349 r. Trudno powiedzieć, kiedy faktycznie zaczął go sprawować. Najstarsze wpisy do jego ksiąg datują się od 2 sierpnia (co mogło wynikać po prostu z respektowania kalendarza kadencji), ale jego poprzednik, Paolo di Negro Brusati z Brescii nie dotrwał do końca kadencji, został zdymisjonowany w połowie maja (wtedy też urywają się jego akta), natychmiast wybrano następcę, a o Nicola di Ranuccio jest mowa jako o „obecnym kapitanie” 27 lip$\mathrm{ca}^{68}$. Akta spraw cywilnych w trybunale tego kapitana (w sprawach sądowych miał on mniejsze znaczenie niż trybunał podesty) zawarte są na 865 kartach w pierwszej kadencji (AC 64-68), przy czym zdecydowana większość spraw toczyła się od września do stycznia, i aż na 1833 kartach w drugiej (AC 76-101). Tę różnicę w działalności trybunałów jeszcze lepiej widać w aktach cywilnych podesty Salamone d. Monaldi z Bettony (był we Florencji egzekutorem sprawiedliwości w 1339 r.): jego księgi i zeszyty obejmujące okres od 2 czerwca do końca sierpnia liczą łącznie 414 kart (wiele zapisanych tylko na jednej stronie, wiele też w ogóle niezapisanych); za okres od początku września do 15 grudnia - $4080 \mathrm{kart}^{69}$. W opasłej księdze akt sędziego apelacji (giudice degli appelli), obejmującej lata 1347-1349, brakuje w ogóle wpisów od początku maja do połowy października. Wydaje się, że była przerwa w funkcjonowaniu tego trybunału, bowiem doktor prawa Bartolomeo di Giovanni z Reggio, który mu przewodził, skończył swoją drugą kadencję 31 maja 1348 r., a jego następca, także doktor prawa, Bartolomeo d. Jacobini z Modeny zasiadał na nim od 11 października do 11 kwietnia 1349 r. $^{70}$

$\mathrm{O}$ poważnych zakłóceniach $\mathrm{w}$ funkcjonowaniu aparatu sądowo-policyjnego jeszcze po ustaniu epidemii świadczy wreszcie rozbój, jakiego dokonać mieli dwaj pachołkowie (obaj z Gubbio) kapitana ludu Nicola Della Sera. Wraz z trzema złodziejami (famosi latrones), florentyńczykami, ograbić mieli nocą ,aptekę" w pobliżu Mercato Vecchio, zabijając przy tym zatrudnionego w nim aptekarza (speziale). Ich łupem paść miała kasetka z 250 florenami w złotej i srebrnej monecie ${ }^{71}$. Wyrok zapadł zaocznie. Ostatecznie trzej florentyńczycy zostali wykreśleni z księgi wyroków na mocy ogłaszanych od 1349 r. amnestii i wykupu wyroków: dwaj w 1351 r., trzeci w 1362 r.

Amnestie i wykup wyroków w latach 1349-1351 świadczą o tym, że po ustąpieniu zarazy traktowano okres jej trwania jako czas ciężkiego zburzenia ładu, którego konsekwencje trzeba było zminimalizować w sposób umożliwiający powrót do porządku prawnego i społecznego. W ten sam sposób postępowano po rewoltach zakończonych przewrotem w układzie sił i krócej lub dłużej trwającą zmianą ustrojową. Pomijając tu tzw. pacyfikacje, które w XIII w. przeprowadzane były m.in. przez legatów papieskich, w XIV wymagały zmiany wyroków sądowych m.in. wojna domowa między Białymi i Czarnymi, rewolta w 1343 r., która zniosła „tyrańskie” rządy Waltera z Brienne, czy późniejsza rewolta ciompich (1378). Po czarnej śmierci wyjętym spod prawa za kontumację, nawet z wyrokami śmierci lub bardzo wysokich grzywien, najczęściej, jeśli tylko ich było na to stać, pozwolono je

\footnotetext{
${ }^{67}$ ASF, AP 276-279; 335-337. Księga wyroków ASF, AP 276 podesty Quirico wygląda jednak na zdekompletowaną, po karcie z numerem 140 zaczyna się karta 312.

68 ASF, Camera del Comune, Camarlinghi, uscita [dalej: CCCU], 45.

69 ASF, AP 338-371.

70 ASF, Giudice degli appelli e nullità [dalej: GA], 6 .

71 ASF, AP 337, f. 32v; AP 334, f. 42v-43.
} 
wykupić i powrócić do społeczeństwa. Nawet w tak drastycznych sprawach, jak zabójstwo w maju 1348 r. pachołka gabelli wina - dokonane po trzecim dzwonie (grzywna w takiej sytuacji wzrastała dwukrotnie), ale w czasie gdy był na służbie i wyszukiwał oszustów tejże gabelli — za które skazano zaocznie czterech mieszkańców Florencji: dwóch na karę śmierci i konfiskatę mienia, dwóch na grzywny po 4 tys. £, trzech z nich (w tym jeden ze skazanych na śmierć) skorzystało w 1349 r. z możliwości ułożenia się z wymiarem sprawiedliwości ${ }^{72}$.

Spadku aktywności trybunałów florenckich nie należy tłumaczyć wyłącznie ucieczkami, zachorowaniami i zgonami wśród familii urzędników „cudzoziemskich” oraz postępującym w związku z nimi chaosem i upadkiem dyscypliny. Zmieniało swój charakter także życie społeczne, zamierały w trudnej do oszacowania skali dotychczasowe przedsięwzięcia, interesy, aktywność mieszkańców. Widać to dobrze w aktach notarialnych tych notariuszy, którzy nie zaprzestali swojej działalności i nie padli ofiarą zarazy ${ }^{73}$. W maju zaczynają z tych akt niemal zupełnie znikać sprawy wcześniej dominujące: kontrakty kupna i sprzedaży, rozliczenia wierzytelności, ustanowienie pełnomocnika (procurator) czy reprezentanta sądowego kobiet (mundualdus), posagi, dziedziczenie itp., ustępując miejsca testamentom. W sierpniu i wrześniu pojawiają się natomiast coraz liczniej sprawy o ustanowienie opieki prawnej nad osieroconymi dziećmi.

W lipcu i sierpniu notariusz Benci di ser Benci uwierzytelnia testamenty niemal codziennie (czasem kilka jednego dnia), najczęściej w domu testatora. Wśród nich aż połowa została spisana własnoręcznie lub podyktowana przez kobiety (wdowy) i często in volgare ${ }^{74}$. Ta seria -35 testamentów uwierzytelnionych w ciągu dwóch miesięcy - kończy się 30 sierpnia, po czym we wrześniu ser Benci uwierzytelnia już tylko 2 testamenty, kolejny w listopadzie, a następny dopiero w marcu $1350 \mathrm{r}$. Zespół akt tego notariusza, obejmujący lata 1334-1362, zawiera wyłącznie testamenty. Przez pierwszych 14 lat, do końca czerwca 1348 r. — jest ich 37, a więc tyle samo, ile ser Benci zarejestrował w ciągu nieco ponad dwóch miesięcy 1348 r. Liczba testamentów florenckich zawierających pobożne legaty, sporządzonych w roku czarnej śmierci - 490, przewyższa liczbę takowych spisanych w latach $1326-1347(355)^{75}$.

„Wycięta” z dokumentacji urzędowej i testamentów część przypadająca na tygodnie apogeum zarazy nie daje, jak widzimy, mocnych argumentów do podważenia obrazu czarnej śmierci podsuwanego nam przez operujące toposem źródła narracyjne. Tam, gdzie wzbogaca go konkret, zazwyczaj

\footnotetext{
72 ASF, AP 336, f. 25.

73 Apriorycznie sformułowane i powtarzane długo w literaturze przedmiotu przekonanie o bardzo wysokiej śmiertelności notariuszy (kontakt z umierającymi chorymi) nie znalazło potwierdzenia w bardzo szczegółowych badaniach nad testamentami bolońskimi. Trudniejszy do zbadania materiał florencki w pobieżnym oglądzie i sondażach wykazuje grupę notariuszy obsługujących miasto i contado florenckie, którzy zaniechali swojej działalności w całym okresie zarazy lub tylko na krótki czas, by podjąć ją tuż po ustąpieniu dżumy. Np. obsługujący mieszkańców Castello Leone i Battifole (dzisiaj prowincja Arezzo) Rustichello di ser Guido z Leccio w marcu rejestruje już tylko 4 akty, w kwietniu — 2, w maju znowu 4 (sprzedaże, posagi), po czym od końca maja do 24 czerwca jest przerwa, następnie liczba ta stopniowo rośnie od lipca (pojedyncze testamenty), by wynieść w sierpniu: 7, a we wrześniu 11, z czego aż 4 akty dotyczyły opieki prawnej (ASF, Notarile Antecosimiano [dalej: Notarile AC] 18430). Wg Falsiniego (s. 450), niemal 100 notariuszy obsługiwało florentyńczyków. W 1338 r. należało do florenckiego cechu sędziów i notariuszy ok. 840 notariuszy, znacząca ich część obsługiwała jednak obszar republiki poza samym miastem (zob. F. Sznura, Per la storia del notariato fiorentino: $i$ più antichi elenchi superstiti dei giudici e dei notai fiorentini [anni 1291 e 1338], w: Tra libri e carte. Studi in onore di Luciana Mosiici, red. T. de Robertis, G. Savino, Firenze 1998, s. 437-515, Aneks II) — część jednak zaprzestała działalności, czy to w skutek śmierci, czy „ucieczki” od obowiązków. S.K. Cohn Jr na podstawie niepełnych danych wskazuje szczyt sporządzania testamentów we Florencji na czerwiec i lipiec (wzrost gwałtowny od połowy maja) i gwałtowny spadek ich liczby w sierpniu, zob. tenże, The Black Death, s. 721.

${ }^{74}$ ASF, Notarile AC 2263 (podobny rytm m.in. w Notarile AC 9293). Por. także rejestrację testamentów w Bolonii, S.K. Wray, Communities and Crisis, s. 109, 156 n., z podobnym nasileniem liczby testamentów i ich dominacją wśród wszystkich aktów w lipcu i sierpniu, szczytowych miesiącach zarazy. Tam też związane z tym refleksje nad historiograficznymi mitami o masowej śmiertelności wśród notariuszy czy też masowym porzuceniu wykonywania zawodu.

${ }^{75}$ S.K. Cohn Jr, The Cult of Remembrance and the Black Death: Six Renaissance Cities in Central Italy, Baltimore 1997, s. 34 , Tab. 1 .
} 
okazuje się, że ma on pełne potwierdzenie: prawa (Boże i ludzkie) przestały działać „per li ministri e esecutori di quelle, li quali, sì come gli altri uomini, erano tutti o morti o infermi o sì di famigli rimasi stremi, che uficio alcuno non potean fare; per la qual cosa era a ciascun licito quanto a grado gli era d'adoperare.” Boccaccio snuje w tym miejscu analogię do bezradności medycyny i medyków, których zastąpili szarlatani, ale aż nadto dobrze poświadczony jest fakt, że priorzy cechów musieli interweniować u podesty i egzekutora sprawiedliwości, by ci nie podejmowali działań przeciwko ludziom, którzy ,z łapanki”, poza procedurą i wbrew przepisom prawa powoływani byli do pełnienia różnych funkcji ${ }^{76}$.

Wydobyte $\mathrm{z}$ tej dokumentacji dane i informacje, a także braki w niej stwierdzone dają się ,przetłumaczyć" na obraz życia miejskiego skomponowany według modelu zastosowanego w literackich i kronikarskich narracjach. Posłużmy się tu przykładem nieregularnego i coraz rzadszego zbierania się rad oraz długich przerw w ogłaszaniu wyroków. Rady zbierały się wczasach „,normalnych” przynajmniej dwa razy w miesiącu, obradując jedna po drugiej czasem w odstępie jednego dnia, czasem kilku dni ${ }^{77}$. Orzekanie sędziów wszystkich trybunałów florenckich mogło wypełnić nawet wszystkie nieświąteczne dni tygodnia. Wszystkie te posiedzenia oznajmiane były mieszkańcom uderzeniem w stosowne dzwony. Na obrady rad ciągnął przez miasto korowód ponad dwustu radnych, na wysłuchanie wyroków sądów przybywały tłumy gawiedzi. Ta istotna, co więcej, regularna strona życia miejskiego znikła zeń niemal zupełnie w czasie ponad dwu miesięcy kulminacji zarazy. Priorzy cechów i chorąży sprawiedliwości wprawdzie podejmowali w „zwykłym” trybie decyzje i uchwalali rozporządzenia, ale czynili to niewidoczni dla mieszkańców, zamknięci w Palazzo Vecchio. Marchionne odmalował tę sytuację jako miasto pogrążone w ciszy (ustać miały przede wszystkim odgłosy codziennego, gospodarczego i społecznego życia mieszkańców), którą z rzadka przeszywają kroki zabłąkanego przechodnia lub gwar procesji.

\section{III „Normalność’ w źródłach z czasów zarazy}

Różnica między dokumentacją urzędową a narracją Boccaccia jest jednak w jednym punkcie zasadnicza: ta pierwsza, pozbawiona często wprost wyrażonego kontekstu zarazy (co najwyżej i rzadko pada uzasadnienie: propter mortalitatem, propter moria), zawierająca interesujące nas tu informacje rozproszone wśród innych zapisek urzędniczej rutyny, wymaga dopowiedzenia, ,przekładu” na obraz miasta terroryzowanego przez zarazę. W „Prologu” zaś zawieszenie praw i ich egzekucji, usytuowane w bezpośrednim kontekście typologii zachowań ludzi pogrążonych w strachu, jest elementem niezbędnym i topicznym obrazu upadku cywilizacji. Z różnicy tej wynika następna - w opisie zarazy w „Prologu” nie ma miejsca na zachowania „normalne”, tymczasem w dokumentacji urzędowej, w testamentach i florenckich księgach rodzinnych znajdujemy wyraźne świadectwa postaw i działań, które mogą się wydawać „nienormalne” w sytuacji szalejącej zarazy, należą bowiem do porządku „normalności”, biegu spraw zgodnie z utartym zwyczajem i sposobami ich załatwiania. Nawet jeśli — jak wskazują na to przytoczone wyżej akta notariuszy — hierarchia codziennych spraw uległa wyraźnej zmianie, ludzie nie zaprzestali dbać o swoje interesy. Umierający potentat finansowy Palla Strozzi dyktuje 4 lipca testament. Nie zamierza jednak darować swojemu szwagrowi Barnie Ciurianniemu zaległych długów (830 florenów); rozkłada je na osiem rat rocznych po 100 florenów. Barna ze swej strony nie zwleka z ożenkiem dwóch (z trzech zamężnych) owdowiałych na skutek zarazy sióstr: Małgorzatę po śmierci Palli wydaje za mąż już 20 września za Lapo di Giovanni Bombeniego z posagiem 400 florenów (o 100 wyższym niż ten wypłacony Palli), 10 dni później celebruje powtórne zamążpójście drugiej siostry, Leny, za Scolaio di Gentile da Sommaia, któremu zapłacić musi 425 florenów

\footnotetext{
76 ASF, AP 372, f. 11v.

77 Por. ASF, LF 28 i 29.
} 
(o 175 więcej niż przy pierwszym zamążpójściu ${ }^{78}$. Rynek dobrych partii wyraźnie się skurczył, wskazany był pośpiech w kontraktowaniu małżeństw.

Zaraza z pewnością przeszkodziła w realizacji wielu działań już przedsięwziętych czy tylko zaplanowanych. Ale jednocześnie stwarzała sprzyjające okoliczności do podejmowania spraw i czynów, zarówno zgodnych z prawem, jak i przestępczych, a nawet do skutecznego przeprowadzenia istotnej zmiany ustrojowej. Florencka oligarchia, korzystając z tego, że szybko traciły na aktualności listy kandydatów na urzędy i funkcje, wyłonionych w wyborach przeprowadzonych w 1343 r. po upadku władzy księcia ateńskiego, Waltera z Brienne, przeprowadziła powołanie komisji (balia) do reformy prawa wyborczego, a ta - obdarzona nadzwyczajnymi uprawnieniami na cały miesiąc sierpień wyeliminowała cechy średnie i niższe z wpływu na system wyborczy ${ }^{79}$. Tego rodzaju ,zamachy stanu" przeprowadzano $\mathrm{z}$ reguły z towarzyszeniem większej lub mniejszej rewolty, w $1348 \mathrm{r}$. jej rolę spełniła czarna śmierć.

W lipcu 1348 r., w pełni lata i szalejącej zarazy, pięciu mężczyzn — bracia i synowie „magnata” Filippozza dei Bardi — najechało „wraz z licznymi wyjętymi spod prawa” kościół św. Krzysztofa w Perticaia. Kościół w tym momencie nie miał rektora (być może zmarł w czasie zarazy), bronili go przed zajazdem parafianie. W czasie skutecznego ataku zabity został z premedytacją wywleczony z tłumu obrońców niejaki Francesco del Forsato ${ }^{80}$. Tego rodzaju zajazdy nie były w contado niczym nadzwyczajnym, a jedyne co może dziwić, przynajmniej z dzisiejszej perspektywy, to przeprowadzenie go w tym czasie i tych okolicznościach.

Przekroczenia prawa i przestępczość w okresie zarazy mają jednak swoją specyfikę, tak jak i odpowiedź na nie wymiaru sprawiedliwości. Rzecz jasna, nie jest możliwe oszacowanie skali przestępczości, a wnioskowanie o jej wzroście lub spadku na podstawie analogii współczesnych, a więc zaczerpniętych z całkowicie odrębnego systemu bezpieczeństwa, inwigilacji i rejestracji przestępczości, jest nieuprawnione. Nawet porównania statystyczne z latami wcześniejszymi czy późniejszymi nie mają tu większego sensu ze względu na poruszoną już kwestię znacznego spadku liczby spraw sądowych czy załamania się systemu notyfikacji przestępstw przez cappellani laici. Oskarżenia i wyroki dotyczące przestępstw popełnionych w czasie zarazy, o których wiemy ze spraw sądowych, toczących się zarówno w czasie jej trwania, jak i po jej ustąpieniu, pozwalają wszakże - właśnie ze względu na ich względnie małą liczbę — na uchwycenie tych zjawisk kryminalnych, które były odbierane przez społeczeństwo jako wyjątkowo groźne i dotkliwe, a przez władze i trybunały także jako wymagające bezwzględnej represji. Do takich przestępstw należały kradzieże, które, przypomnijmy, dały się potężnie we znaki mieszkańcom miasta i contado w czasie wielkiego głodu ${ }^{81}$. Na wiosnę i w lecie $1348 \mathrm{r}$. okazją dla złodziei, także tych z przypadku i zachęconych przez okoliczności, były opustoszałe bądź źle chronione przez chorych domostwa, warsztaty i sklepy. Dominują one w obrazie statystycznym obok napaści (w tym krwawych), niekoniecznie jednak dlatego, że popełniano ich znacznie więcej niż kiedyś, ale dlatego, że wielu innych wykroczeń i przestępstw nie ścigano z racji braku donosu, zawiadomienia, oskarżenia. Ze specyfiką okresu można jednak chyba wiązać znacznie większą niż w „normalnych” latach liczbę kobiet oskarżonych o kradzież (podobny obraz mamy dla okresu głodu) oraz większą liczbę napadów na warsztaty i sklepy. Z tą specyfiką wiązałabym również większy niż

\footnotetext{
${ }^{78}$ Zob. I. Chabot, Reconstruction d'une famille. Les Ciurianni et leurs Ricordanze (1326-1429), w: La Toscane et les Toscans autour de la Renaissance. Cadres de vie, société et croyances. Mélanges offerts à Charles M. de La Roncière, Aix-en-Provence 1999, s. 137-160; teraz także: <http://www.storiadifirenze.org/pdf_ex_eprints/103-Chabot.pdf> [dostęp: 01.10.2013].

79 J.M. Najemy, Corporatism and Consensus, s. $158 \mathrm{nn}$.

${ }^{80}$ AEG 119, f. 26. Kazusem tym zajął się ostatnio J. Figliulo-Rosswurm, „Badia Burning: Noble Criminality and the State in 14th-century Tuscany”, Louisiana State University Grad History Conference, March $2013<\mathrm{https} / /$ pl.scribd.com/ doc/215882188/Violence-in-Medieval-Florence> [dostęp: 15.10.2014]; tu też dalsze losy procesu i sprawy.

${ }^{81} \mathrm{O}$ miejscu kradzieży w obrazie florenckiej przestępczości por. U. Dorini, Il diritto penale, passim; C. Caduff, I „publici latrones” nella città e nel contado di Firenze a metà Trecento, „Ricerche Storiche” 18, 1988, s. 497-521; w 1346 r. wśród osądzonych sprawców 10\% stanowili oskarżeni o kradzież (44\% za przestępstwa przeciwko osobie — bójki, napaści, zabójstwa itd.), wśród nich 15\% to kobiety.
} 
w innych latach odsetek ludzi, którzy — złapani — stanęli przed sądem za poważne przestępstwa, ścigane w procedurze inkwizycyjnej (z oskarżenia publicznego). Okradający florentyńczyków od lutego do sierpnia mieszkaniec Castello di Ricasoli (Montevarchi) wpadł przyłapany przez sąsiadów okradanego domu i dwóch pachołków kapitana ludu, i został powieszony ${ }^{82}$.

Zastanawiać musi rysująca się różnica w surowości represji. Nie jest ona jednak ani jednoznaczna, ani nadto wyraźna. Orzekanie zasiadających w trybunałach florenckich sędziów — zawodowych prawników - było oczywiście podporządkowane florenckiemu prawu, ale to pozostawiało im duży margines swobody, wydawania wyroków wedle własnego arbitrium. W średniowieczu zasada legalizmu nie była znana, władze komunalne (priorzy) wpływały na prowadzoną przez trybunały ,,politykę" ścigania przestępców, zdarzały się, czasami drastyczne, ingerencje w ich pracę. Dotychczasowe badania nad przestępczością i wymiarem sprawiedliwości, w tym w czternastowiecznej Florencji, z reguły nie wnikały w pracę poszczególnych sędziów, bazując przede wszystkim na analizach statycznych ksiąg sądowych. Tymczasem dokumentacja ta pozwala na znacznie głębsze studia, a nawet na spersonalizowanie orzecznictwa, nie tylko zresztą represji karnej. W okresie poprzedzającym nadejście czarnej śmierci trybunał podesty Quirico di Cardulo z Narni — zmagając się z kryminalnymi skutkami głodu - skutecznie ścigał przestępców, szczególnie złodziei. Surowy sędzia, Giovanni di Raineri de Monte skazywał (złapanych!) rzezimieszków na chłostę, amputację ucha (była to kara przewidziana w prawie), wydawał wyroki śmierci na latrones, kradnących w czasie głodu m.in. zbo$\dot{z} \mathrm{e}^{83}$. Florencja nie była miastem, w którym regularnie odbywałyby się na położonym poza murami w pobliżu Arno miejscu spektakle kaźni przestępców (dniem straceń była sobota, dzień ogłaszania wyroków). Zdecydowana większość skazanych na karę śmierci unikała jej uciekając przed wymiarem sprawiedliwości. Na przełomie 1347 i 1348 r. wykonanych wyroków śmierci, zapadłych w trybunale podesty, było jednak sporo: stracono 7 złodziei i rzezimieszków oraz jedną paserkę (poza jedną osobą wszyscy pochodzili z contado), którzy okradali domy i warsztaty, a także mieszkańców contado ze zboża; wykonano również (nie wiemy jednak, czy publicznie), amputacje ${ }^{84}$. Ale już w kwietniu i maju surowe i widoczne represjonowanie słabnie. Wyraźnie też malała skuteczność aparatu represyjnego. Żaden z 12 sprawców trzech zabójstw, skazanych na karę śmierci w trybunale podesty w czasie drugiej kadencji Quirico, nie stawił się przed obliczem sędziego, a tym samym i na miejscu straceń ${ }^{85}$. Zaraza nie tylko osłabiła represję, ułatwiała też ucieczkę przed nią. Co jeszcze ciekawsze, nowa ekipa sędziów podesty Salamone, rozpoczynająca swoją pracę w mieście już ogarniętym zarazą, wyraźnie postawiła na łagodniejsze karanie wykroczeń przeciwko prawu. Zwłaszcza sędzia Jacobus de Munardis potrafił nie tylko skazać zaocznie złodziei i to pokaźnego dobytku na niskie w sytuacji kontumacji grzywny 50 i $100 £^{86}$, ale nawet uniewinniać oskarżonych o kradzież.

Wyroki uniewinniające, zwłaszcza w procesach o kradzież, stanowią znikomy ułamek orzecznictwa, co nie może dziwić. Złodzieje wpadali z reguły na gorącym uczynku albo (większość) zbiegłszy przed wymiarem sprawiedliwości byli automatycznie skazywani zaocznie i wiedli potem żywot banity. Uniewinnienia, które zapadły już po ustąpieniu zarazy, wymagają więc wyjaśnienia. 17 października 1348 r. sędzia podesty wydał wyrok w sprawie Piera di Giovanni Naldi z parafii San Paolo oraz Bartola di Folco z parafii San Pietro Maggiore. Bartolo oskarżył Piera o to, iż ten jako famosus fur okradł lombard dzierżawiony w tejże parafii San Paolo przez dwóch lichwiarzy (feneratores) z Empoli, a jego łupem miały paść złożone tam w kwietniu i maju zastawy, m.in. podbita szata wierzchnia

\footnotetext{
${ }^{82}$ ASF, AP 336, f. 5.

83 Zob. ASF, AP 278, passim.

${ }_{84}$ ASF, AP 276 i 278.

85 Tamże.

${ }^{86}$ Zob. ASF, AP 335, f. 25r — wyrok zaoczny na kobiecie oskarżonej o kradzież zboża, odzieży i sprzętów domowych (50 £); 1 lipca, znowu zaocznie, dwóch złodziei z Florencji za kradzież różnych rzeczy (na liście prawie 80 pozycji) zostaje skazanych na grzywnę $100 £$ każdy. Kradzieże drobne, nawet pieniędzy, np. 3 florenów (co było jednak pokaźną sumą) bywają karane grzywną niższą niż $50 £$ (AP 334, wyrok z 7 sierpnia).
} 
zastawiona przez potężnego Uberta di Bellincione degli Albizzi (jego ojciec, zmarły w czasie zarazy, był kilkakrotnie priorem cechów, w 1338 r. chorążym sprawiedliwości) i płaszcz zastawiony przez tegoż oskarżyciela. Sędzia podesty na podstawie zeznań świadków uznał to oskarżenie za fałszywe i skazał Bartola na grzywnę $500 \mathfrak{£}^{87}$. Wydaje się więc, że okres zarazy sprzyjał także wnoszeniu fałszywych oskarżeń, które stawały się narzędziem wyrównywania rachunków pomiędzy zwaśnionymi stronami. Ryzyko takiego oskarżenia mogło być w końcu niewielkie — pomówiony był zapewne nieobecny w mieście, nie mógł się więc bronić, kontumacja gwarantowała wyrok skazujący, a masowa śmiertelność dawała nadzieję, że będzie to wyrok ostateczny.

Świadectwem specyficznej „,normalności” jest też wspomniana już lawina testamentów, pisanych niekiedy naprędce, własnoręcznie, z pominięciem formularza, in volgare, by zdążyć je już tylko uwierzytelnić przez ściąganego do domu notariusza. Mowa bowiem o społeczeństwie od dawna $z$ testamentem obeznanym. Ale i one mają swoją specyfikę: poza wspomnianymi już językiem i formą, odbiegającymi od notarialnego formularza, własnoręcznie spisaną ostatnią wolę otwiera niekiedy modlitwa, a często wysunięta na pierwsze miejsce dyspozycja dotycząca miejsca pochówku (do czego jeszcze wrócę). Ponieważ sporządzali wówczas testament zarówno już chorzy, jak i jeszcze zdrowi, ale świadomi ryzyka zachorowania i bardzo prawdopodobnej wówczas śmierci, zyskujemy wyjątkową możliwość śledzenia losów poszczególnych członków rodziny na przestrzeni zaledwie kilku tygodni. Angelo Martini pozostawia spory majątek. W napisanej 5 sierpnia in volgare ostatniej woli każdej z córek, których jednak z imienia nie wymienia, pozostawia na przyszły posag po 375 florenów, stosowną część dziedzictwa zapisuje synom, ciężarnej żonie zwraca posag i dodaje 100 florenów, troszczy się też o nienarodzone dziecko różnicując zapis: , temu [dziecku] z ciała pani Urszuli, w zależności od tego, czy będzie to chłopiec, czy dziewczynka (...)”. 17 września sporządza swój testament jego żona, mona Orsola ${ }^{88}$.

W aktach innego notariusza ${ }^{89}$, obsługującego same szczyty społeczeństwa florenckiego, wpis pierwszego z serii testamentów związanych z zarazą pojawia się 11 maja (po umowach kupna i nadaniach posagów). Od połowy maja testamenty zaczynają liczbowo przeważać, a jeżeli pominąć związane z żegnaniem się ze światem zawarcie ,pokoju” (ze stroną, z którą było się w sporze lub nawet ścigało się ją w wendecie ${ }^{90}$ ) czy zeznania świadków w związku z decyzjami wyrażonymi w ostatniej woli, bądź wyznaczenie przez kobiety swoich pełnomocników i mundualdi, to od 14 maja aż do początków sierpnia notariusz ten rejestruje już niemal wyłącznie testamenty. Zaczyna tę serię testament Giovanny, wdowy po „magnacie” Ciampolo Cavalcantim i córki innego „magnata” i bankiera Aldobranda Alfaniego. Kończy - testament jej syna, Domenico di Ciampolo Cavalcantiego. Oba sporządzone zostały ze względu na prawdopodobieństwo rychłej śmierci, i oba, jak można sądzić, przedwcześnie $^{91}$. W swoim testamencie Domenico wyznaczył matkę na opiekunkę dzieci. W jego ostatniej woli przyciąga uwagę jednak inny zapis: zaraz po zadysponowaniu co do miejsca swojego pochówku w grobie rodzinnym w kościele Santa Maria Novella, przeznacza „,comuni et hominibus comunis et universitatis et populi Sancti Nicholai de Calenzano pro restitutione usurarum preceptarum ab ipso comune florenorum auri quinque".

\footnotetext{
87 ASF, AP 334, f. 41v-42v oraz AP 337, f. 31.

88 ASF, Notarile AC 2263, nr 51 i 66.

89 ASF, Notarile AC 9293.

90 Wymagany w procedurze sądowej przy niektórych sprawach akt zawarcia ze zwaśnioną stroną pokoju (pax) musiał mieć miejsce przed notariuszem i być przez tego ostatniego zarejestrowany w jego księgach.

${ }^{91}$ Powtarzalność imion w rodzinie utrudnia czasami pewną identyfikację osób. Ciampolo jest imieniem występującym w tym potężnym i rozrodzonym rodzie bardzo wcześnie; Domenico di Ciampolo Cavalcanti pojawia się w źródłach w 1333 r., jest też wymieniony w kronice Giovanniego Villaniego pod rokiem 1343. Zmarł w 1373 r., a wcześniej wystąpił wraz z synami z rodu i zmienił herb, dając początek rodowi Ciampoli. Skorzystał z prawa do zmiany statusu polityczno-prawnego, jak wielu innych wówczas członków rodów „magnackich” wyrzuconych poza główny nurt życia politycznego i bez możliwości sprawowania władzy w mieście. W październiku 1347 r. został oskarżony o zawiązanie gibelińskiego spisku w Calenzano, zob. szerzej, C. Klapisch-Zuber, Retour à la cité. Les magnates de Florence 1340-1440, Paris 2006 (O spisku Cavalcantiego i jego wystąpieniu z rodu, s. 123 i 201).
} 
Rozliczanie się w ostatniej woli z grzechu lichwy nie jest wielkim zaskoczeniem, choć zdarza się rzadko. Ale w czasie zarazy spotykamy wyznania przewinień jeszcze większego kalibru, przynajmniej w prawie świeckim — defraudacji. Oto Sandro di Simone Tornaquinci, członek jednego z najpotężniejszych rodów florenckich, miał tempore mortalitatis, jak głosiło oskarżenie, sporządzić własną ręką testament, w którym polecił przeorowi dominikańskiego klasztoru Jacopo Passavantiemu oraz podprzeorowi tamże, Pasquiono Bonaccorsi Bentacorde, egzekutorom testamentu, sprzedać stosowną część jego dziedzictwa, aby zapłacić komunie 150 florenów, którą to sumę przywłaszczył był sobie, świadomie popełniając defraudację na szkodę tejże komuny. Sandro przeżył i w styczniu 1349 r. udało mu się przed giudice degli appelli obalić oskarżenie: żadnego testamentu nie sporządził, niczego w sprawie tych pieniędzy nie wyznał ${ }^{92}$. Jeśli było to fałszywe oskarżenie, to może dziwić wmieszanie w całą sprawę osoby o ogromnym wpływie i autorytecie we Florencji, Jacopo Passavantiego.

\section{IV \\ Percepcja zarazy}

\section{Boccaccia katalog postaw wobec dżumy}

W testamentach, także tych pisanych własnoręcznie, w kronikach domowych, różnego typu ricordi bardzo rzadko spotykamy wyrażony wprost strach przed zarazą i śmiercią, timor mortis. A to on miał wyzwolić zachowania, które Boccaccio ujmuje w krótki, zbudowany z opozycji, silnie skontrastowany katalog ${ }^{93}$ : 1. umiar, wstrzemięźliwość połączone z daleko posuniętą ostrożnością i z izolacją; 2. skrajny hedonizm, carpe diem nie bacząc na żadne normy; 3. zachowania pośrednie, bliższe jednak pierwszej grupie; 4. ucieczka (zresztą próżna, traktowana z dużą rezerwą i złośliwą ironią). Ten fragment (obok opisu zarazy jako zagłady), zwłaszcza w odniesieniu do drugiej kategorii — straceńczego hedonizmu — jest najbardziej „oskarżany” o topiczność i zależność od konwencji literackich. Konsekwencją podyktowanych porażającym strachem zachowań jest opuszczenie chorych i zmarłych przez najbliższych i dalszych krewnych, przez przyjaciół i sąsiadów, powtarzane przez wszystkich od czasów Tukidydesa, a dziś najczęściej za Dekameronem przytaczane: „l'uno cittadino l'altro schifasse e quasi niuno vicino avesse dell'altro cura e i parenti insieme rade volte o non mai si visitassero e di lontano: era con sì fatto spavento questa tribulazione entrata né petti degli uomini e delle donne, che l'un fratello l'altro abbandonava e il zio il nipote e la sorella il fratello e spesse volte la donna il suo marito; e (che maggior cosa è e quasi non credibile), li padri e le madri i figliuoli, quasi loro non fossero, di visitare e di servire schifavano". Każda z tych postaw wobec masowej śmiertelności znajduje jednak lepsze lub gorsze potwierdzenie w innych źródłach współczesnych, które, rzecz jasna, też możemy posądzać o posłużenie się toposem, a podane przez nie konkrety uznać za przejawy uniwersalnej w tak ekstremalnych sytuacjach palety zachowań ${ }^{94}$. A to, z kolei, zdaje się pozwalać historykowi na wzięcie w nawias znaczenia tego fragmentu dla całości dzieła.

W katalogu Boccaccia przyciągały dotąd największą uwagę zachowania prowadzące do odwróconych relacji społecznych oraz hedonizm, wzmiankowane bardziej lub mniej topicznie także przez

\footnotetext{
92 ASF, GA 9, filza 4a, f. XVIIv-XIXr. Fragment oskarżenia: „quos CL florenos predictus Sandrus dixit [w testamencie]... se habuisse ac accepisse a comuni Florentie de pecunia et avere dicti comunis, et predictum comunem decepisse et defraudasse scienter et dolose (...)". Inny przykład przyznania się w testamencie do defraudacji (Guccio di Geri Ghiberti, popełnionej w czasie rewolty 1343 r.), zob. A.B. Falsini, Firenze dopo il 1348, s. 484.

${ }^{33}$ Historycy rzadko uwzględniają badania nad składnią zastosowaną przez Boccaccia w „Prologu”. Nie jest jednak obojętna dla jego narracji podkreślana antyteczność i hipotaktyczność stylu (por. m.in. G. Mazzotta, The World at Play).

${ }^{4}$ Por. np. J. Albert, From the Brink of the Apocalypse: Confronting Famine, War, Plague and Death in the Later Middle Ages, Milton Park, (wyd. 2) Abingdon-New York 2010, zwłaszcza rozdz. „Social and economic impact”; a zwłaszcza: S.K. Wray, Boccaccio and the Doctors: Medicine and Compassion in the Face of Plague, „Journal of Medieval History”, 30, 2004, nr 3, s. 301-322.
} 
moralizujących kronikarzy, a w „Prologu” konieczne, by zbudować dla nich antytezę w postaci wiodących vita onesta bohaterów Dekameronu. Powtórzmy: „La nostra brigata dal primo dì fino a questa ora stata onestissima" (VI, Concl.). Szuka się więc w źródłach archiwalnych, i znajduje, potwierdzenia zwłaszcza dla owego carpe diem i bezwstydu: ludzie pili po karczmach dzień i noc (które, wedle prawa, po trzecim dzwonie powinny być zamknięte i zaprzestać wyszynku), kwitł hazard ${ }^{95}$. Źródła sądowe, o czym już była mowa, dostarczają argumentów za takim twierdzeniem tylko w pierwszych miesiącach zarazy, Marchionne zaś pisze, że wszystkie tawerny były zamknięte ${ }^{96}$.

Jeszcze trudniej jest udokumentować „niespotykany dotąd” bezwstyd kobiet, którym usługiwali w chorobie mężczyźni, i który po ustaniu zarazy wiele z nich sprowadził na drogę niecnoty ${ }^{97}$. Jedyne co może zastanawiać $\mathrm{w}$ jednym $\mathrm{z}$ dosyć jednak nielicznych oskarżeń o cudzołożenie w czasie czarnej śmierci, to jego szczegółowość, daleko wykraczająca poza najczęściej stosowaną formułę: ,,se studiose carnaliter cognosci..." przez tego a tego, w podanym czasie i miejscu. Oskarżycielem był mieszkaniec parafii Santa Felicità, którego żona Paola w lipcu, a więc w apogeum zarazy, „wielokrotnie i świadomie", wbrew jego woli cudzołożyła z niejakim Bernardem, synem Aleksandra, z tej samej dzielnicy, ale z innej parafii, w pewnym domu położonym w parafii jej zamieszkania. Nie brak tu pikantnych detali: wielokrotnie i w ciągu wielu dni pozwalała się przez niego inoneste dotykać, obejmować i całować, w tymże domu w łóżku z rzeczonym Bernardem spółkowała, leżała i przebywała obnażona, ,a tenże Bernard goły i ona goła z nim w rzeczonych domu i pokoju się całowali tak za dnia, jak i w nocy"98.

Skrajna ostrożność, a tym bardziej vita modesta nie wzbudzają już, czemu trudno się dziwić, większego zainteresowania dzisiejszych czytelników i badaczy Dekameronu. Marchionne, tymczasem, który w opisie poświęconym właśnie postawom ludzi i ich rozpaczliwym próbom uniknięcia wyroku losu kroczy wyraźnie po śladach Boccaccia, dorzuca dowody na realność dosyć powszechnie zachowywanej ostrożności: nieprawdopodobne wzbogacenie się sprzedawczyń różnego rodzaju ziół, jak ślaz (malva), pokrzywy (ortiche) i ,inne używane do okładów" "99. Co więcej, właśnie ostrożność wraz z umiarkowaniem i ucieczką stają się po czarnej śmierci postępowaniem zalecanym przez medyków.

\section{Topos bezradności medycyny i medyków pół wieku później}

Sześćdziesiąt lat po czarnej śmierci, w pisanych jako pouczenia dla synów pamiętnikach, Giovanni di Pagolo Morelli zawarł rady, jak postępować, a ściślej — stosując tu język militarystyczny — jak walczyć, jaką bronią się posłużyć, by nie paść ofiarą zarazy. Nie był świadkiem czarnej śmierci 1348 r. (urodził się w 1371 r.). Pisząc o niej korzystał z opisów jej współczesnych (przynajmniej kroniki Giovanniego i Matteo Villanich oraz Boccaccia) i powszechnej wśród florentyńczyków pamięci o niej, ale miał też za sobą świeże doświadczenia kolejnych epidemii ${ }^{100}$. Ten fragment Ricordi możemy bez większego ryzyka potraktować jako reprezentatywny przekaz percepcji zarazy na przełomie XIV i XV w. przez ludzi należących do jego warstwy.

\footnotetext{
${ }^{95}$ Generalizuje tak m.in. G. Brucker w cyt. artykule Florence and the Black Death. Kruchym potwierdzeniem może też być z jednej strony dominacja wśród złapanych przez patrole ludzi „bez światła”, z drugiej nieefektywność tych patroli.

${ }^{96}$ Marchionne, s. 232. W 1335 r. było we Florencji 95 tawern, U. Dorini, Il diritto penale, s. 16.

97 „E da questo essere abbandonati gli infermi da' vicini, da' parenti e dagli amici e avere scarsità di serventi, discorse uno uso quasi davanti mai non udito: che niuna, quantunque leggiadra o bella o gentil donna fosse, infermando, non curava d'avere a' suoi servigi uomo, egli si fosse o giovane o altro, e a lui senza alcuna vergogna ogni parte del corpo aprire non altrimenti che a una femina avrebbe fatto".

98 ASF, AP 336, f. 8v; oraz AP 334, niepag. (6 września). Paola została skazana zaocznie na $1000 £$ (podwójny wymiar kary, ze względu na cudzołożenie także w nocy), ale 28 IV $1350 \mathrm{r}$. została wykreślona z księgi po zawarciu pokoju z mężem. Uwaga: „vigore pacis habite et oblationis facte de ea” wskazywałaby na to, że jednak znalazła się w więzieniu i została amnestionowana w rytuale „ofiarowania” więźniów.

99 Marchionne, s. 232.

100 Giovanni di Pagolo Morelli, Ricordi, s. 209-214.
} 
Otwiera go krótkie i dosyć selektywne streszczenie „Prologu” Boccaccia, wzbogacone i skorygowane informacjami z innych źródeł: symptomy choroby i jej błyskawiczny przebieg; śmierć w opuszczeniu; obłęd wielu (,,per farnetico [...] anadavano impazzando per la terra”) — rzucali się do studni, z okien na ulicę, do Arno, szukając śmierci czy to z obłędu, czy z bólu bądź poczucia winy; brak pomocy i opieki; niemożność sporządzenia testamentu lub wysoki jego koszt; pogrzeb inny od zwyczajowego; niebezpieczeństwo opieki nad chorymi (dotykanie jego i jego ubrań), czego mocnym dowodem jest przywołana $\mathrm{w}$ tym miejscu opowieść Boccaccia o dwóch świniach, które padły po kontakcie z ubraniem zmarłego. Po podaniu rozmiarów klęski (,,i due terzi delle persone, cioè dei corpi ottantamila"), Morelli referuje jej przyczyny: nieznajomość choroby; wielka liczba ludności we Florencji (,,che ella fusse mai”), głód w roku poprzedzającym zarazę, który cierpiało co najmniej 80 procent populacji skazanej na jedzenie „korzonków” (erbe) i picie wody. „Zważ, jak bardzo ich organizmy były podatne [na zachorowanie]!”. Widać dobrze w tym wywodzie znajomość ówczesnych studiów nad zarazą i etiologią choroby, niegasnące zainteresowanie czarną śmiercią 1348 r. i ... anachroniczność toposu bezradności medycyny i medyków. Głównej sprawczyni strachu i obłędu w 1348 r. przeciwstawia bowiem Morelli „dzisiejsze” rady medyków, które choć nie gwarantują, że ktoś nie zachoruje, gdy „dosięgnie go chmura bądź smród zepsutego [powietrza] lub oddech innego chorego”, to przecież mniej tych „,dobrze uzbrojonych” umiera niż „,bezbronnych”.

Passus o bezradności medycyny i medyków zalicza się do najbardziej od tradycji literackiej zależnych fragmentów „Prologu”. Historycy medycyny wprawdzie traktowali i traktują przekaz Boccaccia ze szczególną atencją, podkreślając poprawność i dokładność opisu objawów i przebiegu dżumy w jej dwóch głównych postaciach: dymieniczej i płucnej, to jednak równie mocno starają się dowieść wielkiego wkładu ówczesnych lekarzy do lepszego poznania choroby i dróg zakażenia. Podkreślają więc, że zarówno ówcześni wielcy medycy łacińscy: Gentile da Foligno czy Guillaume de Machaut, jak i arabscy (andaluzyjscy): Ibn Khatima i Ibn-al-Khatib potrafili wyzwolić się ze schematu myślowego medycyny klasycznej, uniwersyteckiej - choroba spowodowana jest przez corruptio aeris i przez to zepsute powietrze, zakażone przez ciała i przedmioty, przenoszona - wskazując, że do zakażenia dochodzi także i głównie przez kontakt z chorym (przez oddech chorego, kontakt z jego rzeczami) ${ }^{101}$. Ich obserwacje i wnioski dosyć szybko zresztą wpłynęły na zarządzenia sanitarne walczących z epidemią władz. We Florencji już 3 kwietnia wprowadzono pod rygorem wysokiej grzywny (500£) zakaz przyjmowania chorych przybyłych z Genui, Pizy i innych miejsc dotkniętych epidemią oraz pod karą $200 £$ - sprzedaży należących do nich ubrań wełnianych i płóciennych oraz łóżek ${ }^{102}$. Co nie znaczy, że władze i mieszczanie florenccy nie upatrywali właśnie w corruptio aeris głównej czy nawet jedynej przyczyny choroby i szerzenia się zarazy ${ }^{103}$. Podkreślają badacze także odważne poszukiwania istoty choroby: sekcje zwłok wykonywali medycy w wielu miastach, wsparci w tym przez władze, które występowały do papieża o specjalną dla nich dyspensę. Prośbę taką w końcu czerwca skierowali do Awinionu także florenccy priorzy cechów ${ }^{104}$.

Ludzie, pisze Boccaccio, widząc nieskuteczność lekarzy zaczęli szukać ratunku u różnej maści znachorów i szarlatanów, „de' quali oltre al numero degli scienziati, così di femine come d'uomini, senza avere alcuna dottrina di medicina avuta giammai, era il numero divenuto grandissimo". Zwró-

${ }_{101}$ Literatura „medyczna” jest niezwykle obfita; do klasycznych należy: C.-E.A. Winslow, The Conquest of Epidemic Desease, Medison 1980 (I wyd. 1943); w odniesieniu i z uwzględnieniem Boccaccia zob. także C. de Paolo, Epidemic Disease, s. 60 nn.; A. Carmichael, Universal and Particular: The Language of Plague. Gentile da Foligno zmarł na dżumę w czerwcu 1348 r. Por. też F. Gianni, Per una storia letteraria della Peste, w: The Regulation of Evil: Social and Cultural Attitudes to Epidemics in the Late Middle Ages, red. A. Paravicini Bagliani, F. Santi, Firenze 1998, s. 63-124.

${ }_{102}$ F. Carabellese, La peste nera, $43 \mathrm{n}$.

103 Poza cyt. provvisione z 2 kwietnia, zob. także cyt. list priorów cechów do podesty i jego sędziego fiskalnego (iudex camerae et gabellae) AP 372, f. 39r: ,quod iam propter mortem, quam propter civium Florentinorum absentiam vie et ruge et vici dicte civitatis non fuerint nec tenerentur viziose et propterea in eis exessent putridia, bructure, ex quo defacilem aeris corruptio (...) oriri posset".

104 F. Carabellese, La peste nera, s. 48. 
cenie uwagi na rozkwit znachorstwa można oczywiście interpretować w ramach charakterystycznego dla opisu czarnej śmierci w Dekameronie antytetycznego stylu, w tym miejscu służącego podkreśleniu strachu przed chorobą niosącą nieuchronną śmierć, ale trzeba też zauważyć, że współgra ono z rzeczywistym doświadczeniem czasów zarazy. W statutach florenckiego cechu lekarzy i aptekarzy (Arte dei medici e speziali) czytamy oto, że liczni idioti, w ogóle nieznający sztuki leczenia, którzy wcześniej zajmowali się kowalstwem bądź inną pracą fizyczną (arti mecchaniche), w czasie zarazy zabrali się do leczenia ludzi z ogromną szkodą dla chorych ${ }^{105}$. Przeciwdziałanie takim praktykom miało na celu, rzecz jasna, ukrócenie nieuczciwej konkurencji, milczą o niej jednak statuty cechu z czasów poprzedzających czarną śmierć.

Ricordi Morellego zdają się sugerować, że na przełomie XIV i XV w. - przynajmniej w warstwach zamożnych i oświeconych społeczeństwa florenckiego - topos bezradności medycyny stracił percepcyjną aktualność, zachowując jedynie wartość historyczną i literacką atrakcyjność. By nie paść ofiarą zarazy, należało się kierować dobrymi radami medyków i uporządkowaną już wiedzą płynącą z doświadczeń kolejnych fal epidemii. Referuje je Morelli szczegółowo: sygnały o zarazie gdzie indziej (Romanię i Lombardię atakuje ona wcześniej) zapowiadają jej rychłe pojawienie się we Florencji. To choroba „sezonowa"106 i społecznie zróżnicowana: zaczyna się w lutym, przybiera na sile do końca lipca, a od połowy tego miesiąca uderza „w osoby czcigodne i tych, którzy żyli zgodnie z normami" - śmierć zaczyna więc zbierać mniejsze żniwo, ale głównie wśród migliori. Już w zimie, w okresie zbliżania się zarazy należy wystrzegać się wilgoci i zimna; przestrzegać diety (w tym pić właściwe i we właściwej ilości wino) - której poświęca najwięcej uwagi i wielokrotnie do niej powraca; nie przemęczać się (by się nie spocić), co dotyczy także aktywności seksualnej („,strzeż się przed ciupcianiem i przed kobietami”) i wszelkiej innej poza domem; nie przykrywać się zanadto w czasie snu; wstawać o wschodzie słońca. Wszystkie te rady zmierzają do wzmocnienia odporności, „tak, by zepsute powietrze nie miało dostępu”. W marcu należy już myśleć o ucieczce: „dokąd najlepiej uciec”. Nie należy się z tym wyrywać, zaczekać aż inni mieszczanie się ruszą, ale jednak działać trzeba szybko. Musi to być miejsce, w którym znajdzie się lekarzy; nie należy oszczędzać na wydatkach i w tym celu trzeba zebrać pieniądze skąd się da, bo nie znajdzie się wielu, którzy zechcą udzielić pożyczki (trzeba mieć co najmniej 300 florenów!); wynająć odpowiedni dom dla rodziny; przestrzegać odpowiedniej diety i higieny — stosować i podawać dzieciom zalecane medykamenty, m.in. elettuario (rodzaj powideł leczniczych), odświeżać się (zwłaszcza nos) octem, unikać miejsc tłumnych (także kościołów), unikać wszelkiego kontaktu z zarażonymi bądź mającymi kontakt z zarażonymi; odpędzać melancholię, w zamian poszukiwać przyjemności i radości; zaleca wreszcie Morelli przejażdżki konne i podsumowuje: „prowadź z nimi [rodziną] dobre i zdrowe życie”. Kończy więc swe wskazówki przywołując styl życia „brygady” z Centonovelle. Wszystkie te rady na czele z ucieczką znajdziemy u Tommaso Del Garbo, słynnego lekarza, autora popularnego i autorytatywnego Consiglio contro a pistolenza, napisanego po czarnej śmierci dla mieszkańców Florencji ${ }^{107}$.

Zalecane jest więc życie w umiarkowaniu i z zachowaniem dużej ostrożności, najlepiej w oddaleniu od miejsca objętego zarazą. Topiczna percepcja zachowań ludzkich w czasie zarazy, którą Boccaccio obudowuje psychologiczną interpretacją, już wkrótce po czarnej śmierci zyskuje w traktatach medyczno-praktycznych wiarygodne uzasadnienie ,z wiedzy”108.

\footnotetext{
105 R. Ciasca, L'arte dei medici e speziali nella storia e nel commercio fiorentino dal secolo XII al XV, Firenze 1927, s. 289. 106 Sezonowość jest jednym z elementów opisów kronikarskich.

107 Traktacik Tommasa Del Garbo wydrukowany został w XVI w.; podstawowe wydanie w: Scelta di curiosità letterarie inedite o rare dal sec. XIII al XVII, wyd. P. Ferrato, Bologna 1866, s. 5-59 (tekst, s. 13-49). Napisany został dla florentyńczyków na podstawie doświadczeń 1348 r. (nie ma jednak dowodu, że autor był wówczas we Florencji). Del Garbo zrobił karierę polityczną we Florencji, w której przebywał od 1358 r. do przynajmniej 1367 r. (zm. 1370): był chorążym sprawiedliwości i priorem cechów. Jego traktacik znany jest z wersji in volgare, o której nie wiadomo, czy była wersją oryginalną. Del Garbo zaprzyjaźniony był z Petrarką i należał do bardzo nielicznej grupy medyków, których poeta poważał.

108 Zob. przyp. 28.
} 


\section{3. Śmierć w opuszczeniu i niegodny pochówek}

Bodaj najobszerniejszy fragment „Prologu” Boccaccio poświęca opisowi śmierci w opuszczeniu i pochówków odartych z należytej oprawy. Jego topika nie wymaga w tym miejscu głębszej analizy, którą $\mathrm{w}$ literaturze przedmiotu wielokrotnie zresztą już przeprowadzono. To w końcu jeden $\mathrm{z}$,najczulszych punktów" jego obrazu czarnej śmierci, łatwych do zaatakowania przez weryfikatorów jego zgodności z „rzeczywistością”. Testamenty florenckie z tego okresu, a także bolońskie, jak wykazała to Shona Kelly Wray, nie podsuwają przecież wyobraźni czytelnika obrazów, jakie odmalowali Boccaccio i kronikarze: śmierci w opuszczeniu, bez testamentu, bez należytego pochówku. Przemożny strach przed śmiercią jest $\mathrm{z}$ trudem dostrzegalny nie tylko w dokumentacji urzędowej, ale nawet $\mathrm{w}$ testamentach; wydaje się być nieobecny także w ówczesnych pamiętnikach.

Brat Donata Vellutiego, Filippo, utrudzony ciężką pracą w spółce Bardich, której przybyło mu ponad miarę w związku właśnie z zarazą, zachorował w początku lipca i przez osiem dni zmagał się z wysoką gorączką. Czując nadchodzącą śmierć, w jej przeddzień (12 lipca) wstał z łóżka, ubrał się, obuł w sandały i ruszył do kościoła Santo Spirito. Tam uklęknął przed ołtarzem i modlił się, po czym wrócił do domu bez niczyjej pomocy, jakby był zdrowy, pozdrawiając napotkanych ludzi i będąc pozdrawiany ${ }^{109}$. Filippo przygotowuje się na spotkanie ze śmiercią zgodnie ze sztuką dobrego umierania, to co nadzwyczajne w jego zachowaniu i ocierające się o ponadnaturalną ingerencję, to fizyczna sprawność i naturalność gestów u umierającego człowieka.

Dzięki Donato Vellutiemu możemy też odmalować w scenerii miasta inne zachowania — „normalne” w „nienormalnym” otoczeniu, wybrane z pełną świadomością ryzyka, przeczące „,bestialstwu" ukazanemu przez Boccaccia i z wyraźnym już potępieniem także przez Matteo Villaniego. To o nich będzie później pisał ten kronikarz, niuansując obraz opuszczenia chorych i umierających nawet przez najbliższych ${ }^{110}$, a historycy będą mogli z nich czerpać argumenty zaprzeczające użytemu przez Boccaccia toposowi: „'un fratello l'altro abbandonava e il zio il nipote e la sorella il fratello e spesse volte la donna il suo marito". Donato odwiedza w domu we Florencji krewną, Lizę, która już chora wraz z chorym mężem, Cino, opuściła była swoją rezydencję w contado, by kurować się lub umrzeć w mieście (Cino zmarł w drodze, Liza wkrótce po przybyciu do Florencji). Po odwiedzinach udał się prosto na Borgo San Iacopo, na pogrzeb priora cechów Bernardo Marsili. Władze nie zaprzestały bowiem urządzania uroczystych pogrzebów zmarłych urzędników, wśród których był też najwyższy pośród nich, chorąży sprawiedliwości, Niccolò Berti. ${ }^{111}$ Obojgu krewnym, Cino i Lizie, Donato wyprawi godny pochówek ${ }^{112}$.

W pozostającym w rękopisie pamiętniku Paolo Sassetti ${ }^{113}$ podaje w wyliczance bliskiej formule nekrologu, ale wypełnionej szczegółami dotyczącymi miejsca pochówku i zapisów testamentalnych, poruszającą dziś listę utraconych krewnych, zmarłych w czasie zarazy 1383 r.: „31 lipca zmarła w niesławie [żyła w konkubinacie] Letta, córka Federiga di Pierozzo Sassettiego, w domu Giovanniego di Noldo Porcellini, w Borgo Ogni Santi [we Florencji]. Została pochowana przez braci z kościoła Ogni

\footnotetext{
109 Zapisał cały swój majątek bractwu Orsanmichele. Donato przez następne dwa lata ugadywał się z bractwem, by przejąć ten majątek, Donato Velluti, Cronica domestica, s. 190 n.

${ }_{110}$ Matteo Villani jest, zdaniem G. Zanelli (Italia, Francia e Germania, s. 107), jedynym kronikarzem zarazy piszącym, że ci, którzy poświęcali własne życie opiekując się chorymi, nawet jeśli zachorowali, przeżywali, a ozdrowiawszy mogli dalej czynić tę posługę, co zachęcało innych do podjęcia troski o bliskich. Nie da się tu wykluczyć manipulacji — Matteo pisał o barbaryzacji zachowań sprzecznych z wiarą chrześcijańską: kto dochowywał jej pryncypiów, został więc nagrodzony. Ale nie pisał w zupełnej próżni: potwierdzają to nie tylko ricordanze, także testamenty, nawet fakty, które da się wyciągnąć z enigmatycznych tu niezwykle źródeł.

111 Zob. F. Carabellese, La peste nera, s. 48.

112 Donato Velluti, Cronica domestica, s. 59.

113 ASF, Carte Strozziane, ser. II, 4, f. 67r-68v; ten fragment opublikował w tłumaczeniu na angielski (a następnie w oryginale w wydaniu włoskim) G. Brucker, The Society of Renaissance Florence: A Documentary Study, New York 1998 (reprint 1971), s. 42 n.
} 
Santi [humiliatów] w godzinie nieszporów. Niech diabeł weźmie jej duszę, przyniosła bowiem wstyd i dyshonor naszej rodzinie. Nich Bóg zechce jej zapłacić tak jak tym, którzy zasługują na potępienie. (...) 1 sierpnia spodobało się Bogu powołać do siebie panią Filippę, żonę Pollaia Sassettiego. Została pogrzebana w naszym grobowcu w Santa Maria Novella, pod sklepieniem krużganka, w miejscu pochówku należącym do Soldo di Jacopo Sassettiego. Została złożona do tego grobu na skutek pomyłki fra Bernardino di Maso Manetti, zakonnika z Santa Maria Novella. Myślał, że nas uhonoruje w ten sposób, ale nie było to naszym życzeniem. (...) Niech nasz Pan Bóg przyjmie jej duszę w pokoju, była bowiem dobrą kobietą i zawsze przynosiła honor naszemu domowi.” 26 sierpnia, ciągnie dalej Sassetti, umiera jego najstarszy brat, Bernardo, 24 września Rinaldo di Pollaio Sassetti.

To, co zwraca naszą uwagę w tym wykazie, to akcentowanie miejsca pochówku, nie tylko wtedy, gdy jest ono z jakichś względów niestosowne. W testamentach florenckich troska o właściwy, godny grób w wybranym kościele - w kaplicy rodowej, rodzinnym grobowcu itp. — pojawia się w ćwierćwieczu przed czarną śmiercią ${ }^{114}$, jest też znakomicie widoczna w Kronice domowej Vellutiego, który starannie odnotowuje miejsca pochówków członków swojej rodziny. I, w samej rzeczy, to nie obrazem śmierci w opuszczeniu epatuje czytelnika Boccaccio, lecz horrorem niegodnego pochówku ${ }^{115}$. Teraz, pisze Boccaccio: „Le quali cose, poi che a montar cominciò la ferocità della pestilenza tutto o in maggior parte quasi cessarono e altre nuove in lor luogo ne sopravennero". Zgodną ze zwyczajem, okazałą obrzędowość żegnania i grzebania zmarłych zastąpiły nowe, niegodne praktyki. Zabrakło kobiet czuwających przy umierającym, miejsce płaczu krewnych zajęły śmiech i żarty, rzadko odprowadzało zmarłego do najbliższego, nie zaś wybranego przez niego, kościoła więcej niż dziesięć - dwanaście osób, w dodatku nie byli to czcigodni obywatele, lecz zwykli, opłaceni za tę usługę grabarze, gente minuta, do tego kilku raptem księży (czterech lub sześciu) z nielicznymi zapalonymi świecami lub wcale, którzy nie odprawiając należnego uroczystego nabożeństwa grzebali zwłoki w pierwszej wolnej mogile. Prawdziwy horror czekał jednak ludzi z niższych warstw, a nawet średniej — ich wystawione przed dom ciała kładzione były na mary lub nawet na zwykłe deski nierzadko dwa lub trzy razem: męża obok żony, dwu lub trzech braci, ojca obok syna; za dwoma kapłanami odprowadzającymi z krzyżami trumnę, niesiono trzy lub cztery dalsze, toteż zamiast, jak sądzili, grzebać jednego zmarłego przychodziło im grzebać sześciu lub ośmiu, a niekiedy i więcej. Wreszcie, gdy zabrakło już poświęconego miejsca na cmentarzach, gdy nie sposób już było według dawnego zwyczaju zapewnić każdemu osobnej, własnej mogiły, wykopano duże doły, w które kładziono setkami zwłoki jedne na drugich, niczym towary na statkach, przykrywając je cienką warstwą ziemi.

Zaniechanie religijnej i świeckiej obrzędowości pogrzebu wydaje się być najbardziej „barbarzyńskim" elementem upadku cywilizacji. Odwołanie się do toposu i konwencji literackiej jest w tym miejscu opisu czarnej śmierci ewidentne ${ }^{116}$, ale analiza ograniczona do topiki niewiele poza techniką pisarską Boccaccia wyjaśnia. Anna Pomierny zauważyła podobieństwo między strukturą treściową tej części opisu Boccaccia a florenckim ustawodawstwem antyzbytkowym. Regulując obrzędowość pogrzebową skupiało się ono na najważniejszych pozaliturgicznych jej elementach: czuwaniu i opłaki-

\footnotetext{
114 S.K. Cohn Jr, The Cult of Remembrance, s. 137 n., 159. Zob też J. Chiffoleau, La Comptabilité de l'au-delà: hommes, mort et religion dans la région d'Avignon à la fin du Moyen Age (vers 1320 -vers 1480), Rome 1980, Collection de l'Ecole française de Rome, t. 47, który datuje te zmiany na ok. $1330 \mathrm{r}$.

115 Kwestia ta wymaga podjęcia na nowo: na ile rzeczywiście rozumienie śmierci i l'arte di ben morire przez Boccaccia (bliżej roztrząsano poglądy Petrarki) mieści się jeszcze w nauczaniu mendykantów (zwłaszcza augustianów) i jest przez to podzielane także przez przynajmniej część społeczeństwa, a na ile, jak chciał zwłaszcza Tenenti, autor Dekameronu wyraża już „il nuovo senso di tempo (...) del valore del corpo come organismo", A. Tenenti, Il senso della morte e l'amore della vita nel Rinascimento: Francia e Italia (Torino, 1957), s. 51 n. Zob. także T. Kircher, The Poet's Wisdom, s. 18 n.

116 Jednym z największych literackich opracowań tego toposu jest z pewnością fragment VI księgi De rerum natura Lukrecjusza: „Nie dbano o zwyczaje pogrzebu, jakie dotąd/ Lud tamtejszy wypełniał pobożnie i z ochotą/ W zamęcie i przestrachu każdy najbliższych grzebał/ Sam łzy roniąc, nie dbając o przepis służby nieba./ Nieraz nędza i pośpiech wiodły do zwykłych zbrodni:/ Oto na cudzych stosach przy blasku własnych pochodni/ Kładli ciała najbliższych wśród walki i wśród wrzawy” (wyd. polskie: O naturze wszechrzeczy, tłum. E. Szymański, Warszawa 1957).
} 
waniu zmarłego przez kobiety, rozmiarach i właściwym składzie społecznym konduktu pogrzebowego z klerem, świecami i śpiewem, miejscu odprawienia nabożeństwa i pochówku ${ }^{117}$. To podobieństwo wynika ze struktury samego obrzędu i fundamentalnego znaczenia w życiu mieszczan florenckich zarówno jego części liturgicznej, jak i społecznej. Marchionne, przywołując obraz z „Prologu” dorzuca szczegóły, które pokazują także z innej niż Boccaccio strony groźbę niegodnego pogrzebu: niezwykle kosztownej troski o zapewnienie mu właściwej oprawy. Zakup świec graniczył z cudem, funt wosku kosztował więcej niż jeden floren, toteż nakazano ograniczyć liczbę świec do nie więcej niż dwóch podwójnych ${ }^{118}$; w związku z brakiem mar, grabarze i speziali (należeli do tego samego cechu) żądali za nie strasznych cen; dziesięciokrotnie wzrosły ceny szat, w które odziewano ciała (zamożnych) kobiet; chciwy kler, któremu zabroniono dzwonić w czasie pogrzebów, by nie tylko ograniczyć ich niebywałe koszty, ale i nie straszyć ludzi ${ }^{119}$, tłumnie stawał w konduktach zmarłych zamożnych obywateli, więc ograniczono liczbę zakonników w tym pochodzie do sześciu ${ }^{120}$.

Nie wszystkie przytoczone przez Marchionne regulacje dotyczące pogrzebów dają się potwierdzić w dokumentacji urzędowej z czasów czarnej śmierci. W 1348 r. wystawność pochówków mieszczan ograniczały ustawy antyzbytkowe zawarte w kodyfikacji statutów z lat 1322-1325 oraz bliżej nieznana ich nowelizacja $\mathrm{z}$ roku $1330^{121}$. Zawarty w nich np. zakaz urządzania tłumnych, niekontrolowalnych przez władze zgromadzeń nie był więc związany, jak chcą niektórzy badacze, z zaostrzeniem reżimu sanitarnego ${ }^{122}$, lecz podyktowany obawą przed zagrożeniem, jakie zgromadzenia tego rodzaju mogły nieść dla ładu politycznego i bezpieczeństwa publicznego. Także publiczny lament ograniczono już dużo wcześniej. W miastach włoskich do rubryk statutów miejskich dotyczących egzekwii żałobnych wprowadzano od początku XIII w. skierowany do obywateli, czyli mężczyzn, zakaz exclamare post mortem. Jedynie kobietom pozwalano gdzieniegdzie na rwanie włosów z głowy, drapanie twarzy i rozdzieranie szat na piersi. Potem i tego zabroniono, ograniczając ich udział w lamencie do wdowy lub zawodowych płaczek ${ }^{123}$. Istotniejsza zmiana w prawie nastąpiła już po zarazie (została wprowadzona do kodyfikacji statutów w 1355 r., a następnie w osobnej, jeszcze bardziej rozbudowanej redakcji z 1356 r.), a o konieczności jej wprowadzenia — w związku z konsekwencjami zarazy — zdecydowano w $1351 \mathrm{r}^{124}$ Jedną $\mathrm{z}$ tych konsekwencji była postępująca $\mathrm{w}$ drugiej połowie XIV w. wystawność i rozbudowa ceremoniału pogrzebowego ${ }^{125}$.

Należy mieć to na uwadze interpretując przekaz Marchionne — naocznego świadka i uczestnika coraz bardziej okazałego rytuału funeralnego. Tak jak i to, że zarówno jego wzmianki o niebotycz-

\footnotetext{
117 A. Pomierny, „Zakazana ostentacja. Florenckie prawa antyzbytkowe z pierwszej połowy XIV w. o ceremoniach ślubnych i pogrzebowych", Warszawa 2013 (praca magisterska w Instytucie Historycznym UW), s. 48-51.

118 W Orvieto, w związku z brakiem wosku ograniczono wagę świec do 4 funtów dla „popolanów” i 10 funtów dla szlachty, E. Carpentier, Une ville devant la peste, s. 125.

${ }_{119}$ Uderzenie w dzwon w czasie pogrzebu, regulowane przez ustawodawstwo antyzbytkowe, było jednak przywilejem szlachty, prawników i lekarzy.

${ }_{120}$ Marchionne, s. 231. Już po ustaniu zarazy, 28 września, w czasie sprawowanej przez familię egzekutora zwykłej kontroli miasta (cerca ordinaria) w dwóch kościołach złapano mieszkańca parafii San Lorenzo: „habere e tenere 4 cereos cum lucingnolis de accia”, sprzedawane przybywającym na egzekwie, czyli handlującego nimi poza sklepem (złapany Laurentius Bartoldi Montus z popolo S. Lorenzo, ASF, AEG 111).

${ }_{121}$ Statuti della Repubblica Fiorentina, t. 1: Statuto del capitano del popolo degli anni 1322-25 wyd. R. Caggese, wyd. popr. red. G. Pinto, F. Salvestrini, A. Zorzi, Firenze 1999, Lib. V, R. VII-XI, XIII, s. 201-209.

${ }_{122}$ Ten związek także w pracy historyczki medycyny: I. Naso, Atteggiamenti mentali, reazioni emotive e modelli di comportamento durante le pestilenze dell'ultimo Medioevo, in ,, Sanità, scienza e storia”, 2, 1987, s. 73-96.

${ }^{123}$ D. Owen Hughes, Mourning Rites, Memory, and Civilization in Premodern Italy, w: Riti e rituali nelle società medievali, red. J. Chiffoleau, L. Martines, A. Paravicini Bagliani, Spoleto 1994, s. 23-38.

${ }^{124}$ A. Zorzi, Le fonti normative a Firenze nel tardo Medioevo. Un bilancio delle edizioni e degli studi, w: Statuti della repubblica fiorentina, s. LXXVI. Szczegółowo rozpatruje to Anna Pomierny w cyt. pracy magisterskiej (w 1354 r. zdecydowano, że uchwalone przez biskupa Florencji prawa antyzbytkowe [nie zachowały się], mają obowiązywać także z mocy prawa świeckiego).

${ }^{125}$ S.T. Strocchia, Death and Ritual in Renaissance Florence, Baltimore 1992 (Johns Hopkins University studies in historical and political science), s. 54-59.
} 
nych kosztach godnego pochówku, jak i pierwsza część znajdującego się w „Prologu” opisu pogrzebów odnoszą się do najwyższych warstw społeczeństwa florenckiego, wśród których wiele rodzin $\mathrm{z}$ racji statusu szlachecko-rycerskiego objętych było tylko częścią ograniczeń ustawodawstwa antyzbytkowego ${ }^{126}$. W „normalnych” czasach obowiązywania i zachowywania funeralnych zwyczajów różnice w statusie społecznym zmarłych znajdowały swój wyraz w warunkowanym zamożnością i prawem dostępie do splendoru ceremonii pogrzebowej, w czasach zarazy - w warunkowanym nadal zamożnością, ale przede wszystkim siłą więzi społecznych stopniu degradacji obrzędu. Opłacony udział żałobników rekrutujących się z gente minuta zmierzających z nielicznym klerem i marami do pierwszej wolnej mogiły jest najwyższą miarą upadku ładu społecznego, tak jak najwyższą miarą upadku człowieczeństwa jest układanie w stosy w wykopanych na masowe groby rowach - niczym towary na statku — ciał ludzi, którzy z racji braku środków i wsparcia rodziny nie mogli sobie zapewnić nawet najskromniejszego pogrzebu.

Wbrew pozorom nie ma więc wielkiej różnicy między przesłaniami Boccaccia i Marchionne zawartymi w opisach niegodnego pochówku. Boccaccio wprawdzie pokazuje porzucenie obrzędowości, by podkreślić rozkład więzi społecznych, a Marchionne uwypukla starania, by ją zachować zgodnie ze zwyczajem, ale diagnoza obu jest identyczna. W opisie kronikarza uczestnictwo w kondukcie trzeba sobie kupić za niebotyczne pieniądze, a na trosce o godny pochówek bogacą się najniższe warstwy i zobowiązani do ubóstwa mendykanci. Awans materialny beccamorti, tak jak i służących czy sprzedawczyń ziół, jest znakiem wywróconego porządku społecznego.

Wydaje się ponadto, że powinniśmy ze znacznie większą uwagą potraktować — jak przynajmniej sugerują to kroniki, a także testamenty — porządek duchowy i eschatologiczne przekonania ówczesnych ludzi, mocno ugruntowane dzięki nauczaniu mendykantów. Strach przed pochówkiem bez należytej pompy ogarniał w pierwszym rzędzie ludzi, których na nią było stać, co wprost daje się wyczytać i z „Prologu”, i z kroniki Marchionne. Strach przed pogrzebem bez należytego obrzędu liturgicznego i w byle jakiej lub zbiorowej mogile był udziałem wszystkich. Giovanni Villani zdążył jeszcze zapisać, że ponieważ na skutek śmierci wielu spowiedników i ich obaw przed kontaktem z zarażonymi chorzy byli pozbawieni spowiedzi i komunii świętej, ,papież [Klemens VI] wydał dekret odpuszczający winy i kary księżom, którzy będą spowiadać chorych i udzielać im komunii" 127. W 1336 r. Benedykt XII ogłosił konstytucję Benedictus Deus, w której z całą mocą i autorytetem papieskim potwierdził pogląd, że natychmiast po śmierci ma miejsce sąd indywidualny. Świętych (męczenników i wyznawców) $\mathrm{i}$ innych wiernych zmarłych w stanie bezgrzesznym czeka natychmiastowe obcowanie z esencją Boską, choć aż do momentu Sądu Ostatecznego bezcielesne. Dusze potępionych trafiają do piekła, a większości przechodzą przez czyściec ${ }^{128}$. Konstytucja Benedykta nie rewolucjonizowała teologii, nauczania czy liturgii ani rozwijających się już od dłuższego czasu praktyk religijnych. Nadawała sankcję rozwijającej się w tym kierunku eschatologii i sprzyjała upowszechnieniu się związanych z nią praktyk poza regiony najgłębszej chrystianizacji i mendykanckiej ewangelizacji. Praktyki te i rozbudowa liturgii wynikały z przekonania, że aby pokutujący zmarli dostąpili uczestnictwa w komunii świętych (świętych obcowanie), konieczna jest pomoc żywych — modlitwa za zmarłych. Ta w dodatku — klucze do więzienia, jakim jest czyściec — może pomóc skrócić im to więzienie. W tym samym czasie rozbudowywała się obrzędowość pogrzebowa w kierunku pompy, zainteresowania szczegółem, upamiętnienia silniej akcentującego związek żywych krewnych ze zmarłym niż troskę o los pośmiertny; organizowano nawet - w przypadku np. spowodowanego plagą zaniechania - drugie pochówki. Rozszerzone (głownie od lat 90. XX w.) poza Italię badania, na pierwszym miejscu nad mieszczaństwem, ukazują europejski zasięg (choć $\mathrm{z}$ różnym w stosunku

\footnotetext{
${ }^{126}$ Giovanni Villani podaje (Nuova Cronica, Lib. XII, R. XCIV), że w latach 1336-1338 było 1500 „nobili e potenti che sodavano per grandi al Comune”, czyli „maganatów”, oraz tylko 65 rycerzy pasowanych (,cavalieri di corredo”).

127 Giovanni Villani, Nuova Cronica, Lib. XIII, R. LXXXIV.

128 Szerzej o ówczesnej debacie teologicznej: C. Walker Bynum, The Resurrection of the Body in Western Christianity, 200-1336, New York 1995, Lectures on the History of Religions, t. 15, s. $282 \mathrm{nn}$.
} 
do Italii przesunięciem chronologicznym) istotnych dla tej problematyki zachowań, zmierzających do upamiętnienia, zagwarantowania sobie miejsca wśród żywych, zachowania po śmierci swojej tożsamości: wprowadzenie imienia, a nawet obrazu zmarłego do liturgii i bogatszej obrzędowości parafialnej, a jednocześnie nacisk na korporacyjny i wspólnotowy charakter komemoracji zmarłego. Ludziom ubogim te nowe praktyki i zaangażowanie w nie bractw religijnych przynosiły gwarancję (często niemożliwą ze strony rodziny) właściwego standardu pochówku i modlitwy orędowniczej. Elicie — gwarancję manifestacji statusu społecznego (liczba mszy i nabożeństw komemoratywnych, liczba kleru, liczba zaangażowanych kościołów). Ogromną wagę datujących się na lata 30. XIV w. przemian duchowych związanych z jednej strony z nową eschatologią, z drugiej z napięciami i niepokojami, które generowały kryzys ustroju komunalnego i coraz bardziej wyraźne oznaki zmiany koniunktury gospodarczej i społecznej, dobrze uzmysławiają monumentalne realizacje dekoracji Camposanto w Pizie, Triumf śmierci Buonamika Buffalmacco ${ }^{129}$. Ostatnio Andrea Zorzi w nowej interpretacji lat 30. XIV w. odnalazł w lęku (angoscia) wspólny mianownik dla toskańskich dzieł powstałych w tym samym czasie: fresków Ambrogia Lorenzettiego w Palazzo Pubblico w Sienie, końcowych ksiąg kroniki Giovanniego Villaniego i fresków Buffalmacco ${ }^{130}$. Przesunięcie datacji tych ostatnich na koniec lat 30. uwolniło je od błędnego i zazwyczaj mającego charakter tautologii kontekstu czarnej śmierci, i pozwoliło na zwrócenie większej uwagi na inny kontekst — teologiczny i ówczesną debatę eschatologiczną ${ }^{131}$. To z niej wypływało także, choć nabrało już kolorytu grozy, niewątpliwie związanego z horrorem czarnej śmierci, nauczanie Passvantiego, wyłożone w jego Specchio della vera penitenza.

Dosyć długo późnośredniowieczna troska o zagwarantowanie sobie miejsca wśród żywych i memorię była interpretowana jednostronnie (co najmniej od odkrywcy wielkości renesansu: Burckhardta, do Ariesa czy Chiffoleau, w jakimś stopniu także Le Goffa), jako przejaw rodzącego się indywidualizmu, uznawanego za typowy rys nowożytnej cywilizacji zachodniej. Nowsze badania, w tym dotyczące miast toskańskich i flandryjskich S.K. Cohna, kładą raczej nacisk na tendencję do związania zmarłego - poprzez obrzęd pogrzebowy i memorię - z rodziną, rodem ${ }^{132}$. Odejście więc z tego świata „di molto maggior miseria pieno”: bez sakramentów, z liturgią pogrzebową zredukowaną $\mathrm{i}$ „,byle jaką", pochówek w anonimowym grobie - wszystko to przekreślało jakąkolwiek szansę na zapewnienie sobie miejsca wśród żywych, na memorię i tym samym konieczne wsparcie w skróceniu mąk czyśćcowych. To tłumaczy nie tylko astronomiczny skok cen wszystkiego, co potrzebne było do zwyczajowej oprawy pogrzebu czy wyjątkową na tle wcześniejszych zachowań troskę zamożnych testatorów o właściwe miejsce pochówku, niepomijanie go przez autorów ksiąg rodzinnych we wzmiance o śmierci krewnego, ale również połączone $\mathrm{z}$ ekspiacją miłosierdzie mieszczan erfurckich okazywane zmarłym w corocznej procesji do poza miastem położonych masowych grobów, w których w 1350 r. chowano bez należytego ceremoniału ofiary czarnej śmierci ${ }^{133}$.

\footnotetext{
129 L. Bellosi, Buffalmacco e il Trionfo della Morte, Torino 1974 (nowe wydanie, Milano 2003). Zob. także dodatkową argumentację: L. Bolzoni, La predica dipinta. Gli affreschi del „,Trionfo della morte” e la predicazione domenicana, w: Il Camposanto di Pisa, red. C. Barachini, E. Castelnuovo, Torino 1996, s. 97-114 (lub tejże, Gli affreschi del „Trionfo della morte" del Camposanto di Pisa e la predicazione domenicana, w: taż, La rete delle immagini. Predicazione in volgare dalla origine a Bernardino da Siena, Torino 2002, s. 3-46).

130 A. Zorzi, L'angoscia delle repubbliche.

${ }^{131} \mathrm{O}$ związku tej ikonografii z teologią, C.M. Boeckl, Images of Plague and Pestilence: Iconography and Iconology, Ann Arbor 2000, Sixteenth Century Essays \& Studies, t. 53, s. 69 nn.

${ }_{132}$ S.K. Cohn Jr, The Place of Dead in Flanders and Tuscany: Towards a Comparative History of the Black Death, w: The Place of the Dead: Death and Remembrance in Late Medieval and Early Modern Europe, red. B. Gordon, P. Marshall, Cambridge 2000, s. 17-43.

133 A. Löther, Prozessionen in spätmittelalterlichen Städten. Politische Partizipation, obrigkeitliche Inszenierung, städtische Einheit, Köln-Weimar-Wien 1999, s. 183-208. Procesja wiodła do kościoła i na cmentarz w Neuses, gdzie miano pogrzebać w czasie zarazy 12 tys. jej ofiar.
} 


\section{Zagłada z wyroku boskiego — topos a dokumenty i działania władz}

Zauważono już w literaturze przedmiotu, że odwołania do „wielkiej śmiertelności” stają się częste $\mathrm{w}$ dokumentacji urzędowej dopiero po wygaśnięciu epidemii. Dodajmy do tego spostrzeżenie, że w decyzjach podjętych w ostatnich tygodniach trwania zarazy i zaraz po jej ustąpieniu powoływanie się na braki w obsadzie urzędów i funkcji czy na niemożność egzekucji prawa i zobowiązań wyrażane jest już w katastroficznym kontekście i emfatycznej retoryce. W provvisioni uchwalonych w ostatniej dekadzie sierpnia powtarzają się zwroty: „considerantes et advertentes pestis immane contagium, que civitatem Florentie et generaliter totam provinciam immo plurimas partes orbis hactenus vexavit enormiter et infecit, et quam plurima pericula et iacturas, que ipsa pestis induxit in humanis corporibus, quam in rebus...” ${ }^{134}$; ,,propter graves pestilentias, que hactenus civitatem et comitatum Florentie enormiter infecerint, propter que plerique ex suis [podesty] judicibis, notariis... decesserunt"135. Ten nowy ton areng otwierających postanowienia władz odsłania możliwą, jak się wydaje, dopiero po osiągnięciu apogeum śmiertelności percepcję spustoszeń spowodowanych przez zarazę. W tym sensie stworzony ex post przez Boccaccia obraz tego apogeum różni się właściwie tylko literacko od obrazu zarazy, którym posługują się florenckie władze w swoich dokumentach od momentu, w którym rzeczywiste rozmiary klęski stały się dobrze widoczne i dramatycznie odczuwalne.

Coraz liczniejsze od przełomu lata i jesieni 1348 r. wzmianki o enormis mortalitas tworzą uderzający kontrast $\mathrm{z}$ wcześniejszym niemal zupełnym milczeniem dokumentacji urzędowej o zarazie. We Florencji, co prawda, wspomina się o niej wcześnie, ale aż do końca sierpnia bardzo rzadko. Za każdym razem przywołanie wówczas zarazy jest uzasadnieniem dla decyzji modyfikujących statuty komunalne bądź sankcjonujących odejście od prawa. 2 kwietnia, w sytuacji, jak się powiada, szerzenia się w Toskanii śmiertelnej zarazy (,,insolite et subito mortales infirmitates") i dotarcia jej już do Florencji i jej contado, gdy trzeba się obawiać, że także i tu szybko się rozprzestrzeni, priorzy i chorąży sprawiedliwości, pod naciskiem obywateli i po naradzie z innymi urzędnikami - uznając za główną przyczynę zarazy zepsute powietrze (,ex [...] corruptione et infectione aeris, que ut plurimum procedit ex rebus et corporibus putridis et corruptis") — powołują na rok nową magistraturę złożoną z 8 prudentes et honorabiles obywateli miasta. Ich zadaniem ma być oczyszczenie miasta i przedmieść z wszelkich nieczystości i zarażonych ludzi („omnem putredinem et res putridas et personas infectas"), z tym jednak wyjątkiem, że tych ostatnich nie wolno usuwać z ich domów i warsztatów; mają także usunąć z Mercato Nuovo i jego okolic sprzedaż ryb i mięsa. Przy okazji — zważywszy na najwyższy walor tego centralnie położonego miejsca, z którego jednak kupcy i inni honorabiles obywatele, mający tam swoje sklepy i warsztaty zwykli są uciekać przed smrodem, zwłaszcza w gorące dni — miała ta magistratura zadbać o jego wspaniały wygląd (,,actari et ornari et decorari facere”), nawet $\mathrm{z}$ prawem do wyburzenia domów ${ }^{136}$.

Podobne milczenie odnotowano również gdzie indziej. W rozporządzeniach bolońskich Signori zaraza w czasie jej trwania wspomniana jest tylko cztery razy ${ }^{137}$. Tłumaczy się to milczenie dwojako i do pewnego stopnia komplementarnie ${ }^{138}$ : mimo docierających od jesieni $1347 \mathrm{r}$. informacji o szerzeniu się zarazy ani władze, ani mieszkańcy nie mieli wyobrażenia jej rzeczywistej skali, ani narzędzi do zapobieżenia jej w jakikolwiek sposób. G. Zanella zauważył, że nieumiejętność opisania

\footnotetext{
134 ASF, Prov. Reg. 36, f. 1r, 23 sierpnia.

135 ASF, Prov. Reg. 36, f. 7r, 29 sierpnia.

136 ASF, PR 35, f. 133v; całość prowizji jest wydrukowana m.in. w: F. Carabellese, La peste nera, s. 45 n., przyp. 2.

137 S.K. Wray, Communities and Crisis, s. 152; w rozporządzeniach bolońskich dotyczących skądinąd poboru podatków czy zebrań cechowych (mimo braku wymaganej liczby zgromadzonych), sfomułowania odnoszące się do wyroków boskich po raz pierwszy użyto 24 sierpnia (dotyczy niemożności sprawnego poboru podatków, jak we Florencji); ponownie 4 września i 31 października.

${ }_{138}$ G. Zanella, Italia, Francia e Germania, s. 49 nn.; E. Carpentier, Une ville devant la peste, s. 121, o milczeniu źródeł oficjalnych.
} 
tego, co się dzieje, dotyczy także przekazów narracyjnych pisanych w trakcie jej trwania. Dokumentacja oficjalna, silnie sformalizowana, oddaje w pierwszym rzędzie procedury i rutynę urzędowania, w które z trudem wdzierały się decyzje i przedsięwzięcia nadzwyczajne, podejmowane najczęściej z mniejszym lub większym opóźnieniem ${ }^{139}$. Jej formalizm i w pewnym stopniu także formalizm procedur dobrze ilustruje porównanie protokołów z przeprowadzanej co miesiąc przez egzekutora sprawiedliwości lustracji familii podesty czy kapitana ludu z zapisami pochodzącymi z innego rodzaju dokumentacji. Zapis tej lustracji to po prostu lista wszystkich sędziów, notariuszy i zbrojnych pachołków zgodnie ze stanem wyjściowym. Nie znajdujemy tu informacji o śmierci czy ucieczce któregoś z funkcjonariuszy ${ }^{140}$. Tymczasem, pod koniec sierpnia priorzy cechów wraz z chorążym sprawiedliwości stwierdzają, o czym była już mowa, że wśród familii podesty wiele było ofiar zarazy ${ }^{141}$. Ponadto, nie można wykluczyć spowodowanych chaosem i ucieczką bądź śmiercią m.in. notariuszy i skrybów strat w tej dokumentacji, skoro najobszerniejsza, nowelizowana pod naciskiem zarazy legislacja dotycząca reżimu higienicznego i sanitarnego zachowała się tylko dla Pistoi i to przypadkowo $^{142}$. Gian Maria Varanini słusznie jednak zauważył, że rozczarowanie badaczy tym stanem rzeczy jest wynikiem naszych nieco anachronicznych wyobrażeń o bonum commune i przenoszenia na tamtą epokę dzisiejszych koncepcji dotyczących funkcjonowania państwa i społeczeństwa ${ }^{143}$.

Uchwytna w źródłach narracyjnych napisanych ex post percepcja zarazy, posługująca się utrwalonymi, określonymi toposami, znajduje więc swoje, choć słabsze odbicie w dokumentacji urzędowej, ale także dopiero od momentu, gdy lepiej widoczne są jej skutki ${ }^{144}$. Dostrzegamy w niej niemal całą paletę zjawisk, zachowań i przekonań, z których Boccaccio zbudował horror florenckiej czarnej śmierci. Zatrzymać się wypadnie przy tych zwłaszcza, które historycy uznali za przerysowane bądź szczególnie konwencjonalne, zależne od literackiej topiki: zarazie jako wyroku boskim i toposie zagłady.

Zaraza był kolejnym kataklizmem, które w krótkim czasie (katastrofalna powódź 1333, zaraza 1340, głód 1346/7), spadły na Florencję. Według Giovanniego Villaniego (i wielu innych kronikarzy), zostały te plagi zesłane przez Boga jako kara za grzechy, a ich sprawcą był wyjątkowo niekorzystny układ planet. Giudizio di Dio, wyrok Boży za grzechy był powszechnym sposobem percepcji wielkich klęsk elementarnych, toposem dobrze już wówczas zadomowionym w wyobraźni ${ }^{145}$. Wiele lat po pierwszym ataku czarnej śmierci w liście do Guida Settimo, arcybiskupa Genui, Petrarka pisze o niej i jej nawrotach: „Nazwę dżuma (pestis) słyszało się i czytało o niej w księgach, ale nigdy dotąd nie

139 G.M. Varanini, La peste del 1347-50 e i governi dell'Italia centro-settentrionale: un bilancio, w: La peste nera: dati di una realtà, s. 288, jako jeden z nielicznych badaczy słusznie podkreślił małą przydatność tej dokumentacji, zwłaszcza protokołów z posiedzeń Rad, jako źródeł oddających mechanizmy i zachowania społeczne uruchomione przez zarazę.

${ }_{140}$ ASF, AEG 100 - gdzie takie comiesięczne lustracje familii podesty Quirico di Cardulo z Narni (jego familia składała się z 13 sędziów, w tym jeden doktor praw, trzech tzw. rycerzy towarzyszy, 37 notariuszy i skrybów, 12 giermków [donzelli], 17 zbrojnych pachołków [berroviari], nadto służyło 17 koni i 1 muł). Dokładniejsze pod tym względem są księgi kontroli sprawowania urzędu po zakończeniu urzędu (sindacato). Nie wszyscy, np., członkowie familii podesty Salamona Monaldi, stawili się na nią, w związku z czym zostali przez syndyków wezwani (Sindicati Podestà 2 [Busta 1], f. 5v i 6, gdzie aż 41 członków familii tego podesty, w tym jeden sędzia i siedmiu notariuszy, zostało wezwanych do stawienia się).

${ }^{141}$ ASF, Prov. Reg. 36, f. 7r-7v, 29 sierpnia.

142 A. Chiapelli, Gli ordinamenti sanitari del Comune di Pistoia contro la Pestilenza del 1348, „Archivio storico italiano”, ser. IV, t. 20, 1887, s. 3-24. G.M. Varanini, La peste del 1347-50, s. 288 n.

143 G.M. Varanini, La peste del 1347-50, s. 288. Trzeba jednak zauważyć, że i on „rozprawiając się” z wizją chaosu, w jakimś stopniu „weryfikuje” najważniejsze źródło tej wizji: Dekameron.

144 A.B. Falsini, Firenze dopo il 1348, rekonstruując nie tylko konsekwencje zarazy, ale i jej przebieg, sięgał przede wszystkim do dokumentacji wytworzonej w miesiącach bezpośrednio po ustaniu epidemii, w której odwołania do zarazy są nieustanne i wiele mówiące. Wybór cytatów źródłowych i krótkich opracowań znajduje się także w „La peste nera (1347-1350)” (maszynopis na potrzeby Seminario di storia medievale, Università degli Studi di Firenze, 1969/1970).

${ }_{145}$ Zob. szerzej: G. Ortalli, „Corso di natura” o „,giudizio di Dio”. Sensibilità collettiva ed eventi naturali, a proposito del diluvio fiorentino del 1333, w: tenże, Lupi, genti, culture. Uomo e ambiente nel medioevo, Torino 1997, s. 155-188; a zwłaszcza: Le calamità ambientali nel tardo Medioevo europeo: realtà, percezioni, reazioni, red. M. Matheus et al., Firenze 2010. $\mathrm{O}$ atmosferze niepokoju i strachu w Toskanii w latach poprzedzających czarną śmierć por. cyt. artykuł: A. Zorzi, L'angoscia delle repubbliche; w szerszym kontekście por. J. Berlioz, Catastrophes naturelles et calamités au Moyen Age, Firenze 1998. 
widziano ani nie słyszano o powszechnej dżumie, która nadeszła, by zniszczyć świat. Ta już od dwudziestu lat tratuje wszystkie kraje, tak że nawet jeśli w jakimś miejscu może być uśpiona czy szerzyć się powoli, z żadnego nie została wypleniona. Toteż, gdy już wydawało się, że odeszła, powraca i po krótkiej radości nastają z nowym impetem jęki i żałoba. Jest, jak sądzę, dowodem gniewu Bożego i ludzkich występków; gdyby te kiedyś się skończyły lub zmniejszyła ich liczba, być może kary niebios byłyby łagodniejsze"146. Petrarka zauważa niezwyczajność czarnej śmierci 1348 r. i jej nawrotów, pisze o powszechnej (universalis) dżumie/zarazie jako nowym zjawisku, ale sytuuje je w tradycyjnej kategorii: gniewu Bożego za grzechy ${ }^{147}$. Dla fra Paolo Bilenchiego, sporządzającego smutną i długą listę zmarłych braci z florenckiego konwentu dominikanów Santa Maria Novella, była to „divina seviens justitia, qua totius orbis excidium riguit" $" 148$.

Wydaje się, że rację ma większość interpretatorów Dekameronu, dostrzegająca w „Prologu” identyczną jak u Petrarki, jak u Matteo Villaniego i jego brata, Giovanniego, jak u całej rzeszy kronikarzy, percepcję dżumy jako gniewu Bożego: ,...la quale, per operazion de' corpi superiori o per le nostre inique opere da giusta ira di Dio a nostra correzione mandata sopra i mortali...”. Taka konstatacja nie pozbawia opisu Boccaccia znaczącej i oryginalnej cechy: obramowany konwencjonalną i chrześcijańską interpretacją zarazy (sprawczość gniewu Bożego i/bądź ciał niebieskich) nie podnosi moralnego czy religijnego znaczenia epidemii; odczłowieczające jej skutki polegają na przyjęciu zasady: jak długo się żyje, a nie — jak się żyje ${ }^{149}$. Alternatywa - czy to z powodu gniewu Bożego, czy działań ciał niebieskich — zwłaszcza, jeśli ją umieścić w kontekście kilku poświęconych kataklizmom lat 30. i 40. fragmentów kroniki Giovanniego Villaniego, wydaje się raczej pozorna ${ }^{150}$. Służy, jak sądzę, podkreśleniu strachu i skonkretyzowaniu przyczyn owych immaginazioni, które ten rodził u ludzi i wystawiał ich na życie w ułudzie; także uciekinierów z miasta: „e cercarono l'altrui o almeno il lor contado, quasi l'ira di Dio a punire le iniquità degli uomini con quella pestilenza non dove fossero procedesse,

\footnotetext{
146 Petrarca, Epystole seniles, wyd. P. Stoppelli, Roma 1997, $\mathrm{nr}$ X, 2: ,... nomen pestis auditum erat et in libris lectum; pestis universalis exhausura orbem visa non erat nec audita: hec per annos iam viginti ita omnes terras proterit, ut intermissa quidem alicubi forsitan aut lentescens, extincta utique nusquam sit adhuc; ita in dies, dum visa est abiisse, revertitur brevique gaudio circumventos aggreditur. Et hec ipsa divine, nisi fallor, ire testis ac scelerum humanorum; siquando finirentur aut decrescerent, celestes quoque mitescerent ultiones" <http:/ww2.bibliotecaitaliana.it/xtf/view?docId=bibit000342/ bibit000342.xml.> [dostęp: 15.10.2014]. Z krótszej jednak perspektywy — w liście Do Sokratesa (22 VI 1349), wątpiąc w możliwość ogarnięcia rodzaju i skali nieszczęść, jakie zgotowała czarna śmierć, zadawał dramatyczne pytanie: dlaczego na nas spadł taki gniew Boży? Owszem, zasługujemy nań, a może i na jeszcze większy, ale przecież zasłużyli nań i nasi ojcowie, a - jeśli będzie taka wola Boża - i nasi wnukowie (Familiares, VIII, 7). O biblijnych źródłach toposu o zagładzie ludzkości za jej grzechy i o jego funkcjonowaniu w okresie czarnej śmierci zob. A. Carmichael, Universal and Particular. Trzeba jednak zauważyć, że narracje florenckie nie wyróżniają się językiem apokaliptycznym, zob. J. Albert, From the Brink of the Apocalypse, zwłaszcza „Prologue”.

${ }_{147}$ L. Green, Chronicle into History: An Essay on the Interpretation of History in Florentine Fourteenth-Century Chronicles, Cambridge 1972, s. 13, 37.

148 S. Orlandi, „Necrologio” di S. Maria Novella, t. I, Firenze 1955, s. 65, gdzie zanotowanych 83 zmarłych zakonników; A. Carmichael, Plague, (Tab. 3-1.), podaje liczbę pochówków w klasztorze: od marca do końca maja nie odnotowano żadnego, w czerwcu - 31, w lipcu - 22, w sierpniu - 2 i w listopadzie - 1. Pewna liczba braci musiała więc umrzeć poza Florencją.

149 Por. A. Tenenti, La rappresentazione della morte colletiva nel „,Decameron”, „Intersezioni”, 12, 1992, s. $235-246$.

150 T. Kircher, The Poet's Wisdom, s. 48 n., podkreśla zasadniczą różnicę między Villanim (Matteo) a Boccacciem — ten pierwszy interpretując przyczyny i samo zdarzenie mieści się w doktrynie (iudicium Dei), traktuje peste jako symbol prawd eschatologicznych; ten drugi szuka wytłumaczenia poza znaczeniem doktrynalnym, posługując się wypowiedziami antytecznymi pozostawia czytelnikowi ocenę. Akcentując strach, ukazuje stan umysłów (w tym swojego) i wprowadza nowe rozumienie historii: dżuma jest momentem historycznym, który „,konfrontuje każdego z przeznaczeniem, determinuje nie tylko pole widzenia i zachowanie aktorów historycznych, ale także percepcję tych, którzy rejestrują ich działania i w konsekwencji tych, którzy czytają ten zapis”. Zob. też, zwłaszcza w odniesieniu do kronikarstwa: E. Artifoni, La consapevolezza di un nuovo assetto politico-sociale nella cronachistica italiana d'età avignonese: alcuni esempi fiorentini, w: Aspetti culturali della società italiana nel periodo del papato avignonese, Todi 1981, Convegni del Centro di studi sulla spiritualità medievale, t. 19, s. 79-100, zwł. s. 83-87; A. Carmichael, Universal and Particular; The Black Death, wyd. i tłum. R. Horrox, Manchester 1994, s. 93 nn. (antologia źródeł w tłumaczeniu na angielski, z komentarzem).
} 
ma solamente a coloro opprimere li quali dentro alle mura della lor città si trovassero". Jakby na potwierdzenie tych słów pisze w swoich „,pamiętnikach” Luca di Matteo da Panzano: „Zmarł rzeczony Niccolò, syn pana Luki, w Bolonii w lipcu 1348 r., dokąd uciekł przed dżumą, i zmarł od dżumy" "151.

Określenie juditium Dei znajdujemy także w kilku oficjalnych dokumentach władz florenckich (provvisioni). Jednak nie od samego początku nadejścia kataklizmu. W cytowanym już zarządzeniu z 23 sierpnia - wydanym na rzecz emptores et tenitores gabellarum, czyli poborców cła bramnego i innych podatków, którzy sami, bądź ich poręczyciele, nie byli w stanie, wobec drastycznego zmniejszenia się poboru, rozliczyć się z komuną - uznaje się, że stało się to „non sua culpa sed dicto Dei juditio" 152 . W tym samym czasie, a więc także dopiero w okresie szybkiego spadku zachorowań, pojawia się to wyrażenie w dokumentacji bolońskiej, dotyczącej zresztą podobnych spraw, oraz innych miast: Sieny (fatalitas) czy Wenecji (,casus fortuitus, qui divino iudicio nuper emersit”). Te i podobne sformułowania nie występowały w tego rodzaju dokumentacji wcześniej ${ }^{153}$. Wdarły się do formularza, jak się wydaje, nie tylko i nawet nie przede wszystkim z powodu rozmiarów kataklizmu, ile ze względu na jego skutki. Rzeczywistość po zarazie wymagała działań prawnych i regulacji, które podważały dotąd obowiązujące przepisy, rozporządzenia i umowy. Uzasadnieniem dla tych doraźnych zmian było właśnie „non sua culpa sed Dei juditio”. Czy oznacza to zarazem, że zastosowane w dokumentacji urzędowej podobne lub identyczne sformułowania jak w źródłach narracyjnych, w których opisują one apokaliptyczny, niespotykany dotąd wymiar zarazy, odbijają jednak w tej pierwszej różniącą się nieco lub w innym kontekście sytuowaną percepcję kataklizmu?

Sugeruje taką różnicę Matteo Villani w ostrym, biblijnym słowem kreślonej refleksji moralnej, otwierającej jego kontynuację kroniki brata i nawiązującej jednocześnie do wymowy jej ostatnich ksiąg: „,z powodu plamy grzechu [pierworodnego] na cały rodzaj ludzki spadają klęski doczesne i nędza wielka, i niezliczone zło, które objawiają się w świecie na różny sposób i poprzez różne i dziwne czasy i ruchy, jako to niepokoje wojenne i walki, wściekłość ludów, niestabilność królestw, okupacje tyranów, zarazy, wielka śmiertelność i głód, pożary, klęski i inne kataklizmy. Ludzie — jakby z niewiedzy zaskoczeni - im więcej się im dziwią, tym mniej pojmują wyroki boskie i nie znają rady i lekarstwa na nieszczęścia, skoro z wiedzy o podobnych zdarzeniach w przeszłości nie wyciągają żadnych nauk, zaś w tych czasach, które przynosi jasne oblicze pomyślności, nie potrafią zachowywać się z należytym umiarkowaniem, doprowadzając pod ciemną zasłoną ignorancji sprawy doczesne do przemijającego i wątpliwego końca"154. Moralizatorski wywód drugiego z Villanich zwraca przy okazji uwagę na nieświadomość przełomu, na niemożność odczytania przez ludzi wyroku Bożego, gdy ten nadchodzi.

Na zaprzeczenie takiej konkluzji poszukać musimy argumentów poza sformalizowanym językiem florenckich provvisioni, w sferze niektórych zjawisk i przedsięwzięć podejmowanych przez władze: organizacji procesji, wyrzucenia z miasta prostytutek i troski o więźniów. Wybrane one zostały nieprzypadkowo. Procesje były głównym środkiem porozumiewania się wspólnoty z Bogiem i ,wpływu" na jego decyzje. Na Zachodzie pierwsza wielka procesja, całej wspólnoty, znana nam z przekazu Grzegorza z Tours, została zorganizowana przez Grzegorza Wielkiego na początku jego pontyfikatu, w celu wybłagania u Boga uśmierzenia szalejącej w Rzymie dżumy ${ }^{155}$. Działania w dwóch pozostałych sferach mieszczą się zaś, z dzisiejszego punktu widzenia, w polityce sanitarnej i zaostrzeniu reżimu sanitarnego, jakiego należy się spodziewać w sytuacji zarazy. Wprawdzie praktyka kordonów

\footnotetext{
151 Brighe, affanni, volgimenti di Stato: le ricordanze quattrocentesche di Luca di Matteo di messer Luca de' Firidolfi da Panzano, wyd. A. Molho, F. Sznura, Firenze 2010, Memoria Scripturarum, t. 5, s. 365.

152 ASF, Prov. Reg. 36, f. 1r-2r.

153 G.M. Varanini, La peste del 1347-50, s. 291. Wiązał on to jednak z zaskoczeniem, nieprzygotowaniem na nieznane wcześniej rozmiary i zasięg zarazy.

154 Matteo Villani, Cronica, cap. I.

155 Jej szczegółowy opis w: Grzegorz z Tours, Historie. Historia Franków, tłum. K. Liman, ks. T. Richter, oprac. D.A. Sikorski, Kraków 2002, ks. X, 1, s. 417-420; oraz w kazaniu Grzegorza Wielkiego, Letania septiformis, MGH, Epistolae, t. II, Berolini 1890, s. 365-367.
} 
sanitarnych i kwarantanny rozwinęła się na dobre dopiero po czarnej śmierci, to jednak znana była już wcześniej i także w 1348 r. próbowano ją, choć często zbyt późno, wprowadzać. Skuteczna okazała się w czasie czarnej śmierci w Mediolanie, który niemal nie został dotknięty zarazą.

Dżuma opanowała Florencję w najbardziej intensywnym pod względem liturgicznym okresie roku kościelnego: Wielki Post i Wielkanoc, Wniebowstąpienie, Zesłanie Ducha Świętego, Boże Ciało (19 czerwca), zaraz po nim święto patronalne (św. Jana), 26 lipca obchody patronki miasta, św. Anny. Rozproszone wzmianki o organizowaniu licznych procesji w tym czasie - głównie odnotowane wydatki z kasy komunalnej — znajdują potwierdzenie w kronice Marchionne, który sugeruje, że obok pogrzebów była to w zasadzie jedyna zauważalna aktywność ludzi na ulicach. Kronikarz, który był dwunastoletnim chłopcem w czasie czarnej śmierci, nie musiał ich nawet pamiętać, by pisać z przekonaniem, że się odbywały ${ }^{156}$.

Podobnie, w kategoriach działań błagalnych, by uśmierzyć gniew Boży, powinno się zinterpretować ogłoszone w 1348 r. amnestie dla więźniów Stinche, mimo iż należały one do utrwalonego już rytuału miejskiego ${ }^{157}$. W obszernym fragmencie Nowej Kroniki Giovanniego Villaniego, poświęconym opisowi wielkiego głodu D'uno grande caro che fu in Firenze e d'intorno e in più parti (L. XIII, R. LXXIII), który jest jednocześnie peanem na cześć sprawnych rządów komunalnych, czytamy: „A przy całej wielkiej potrzebie, w jakiej znalazła się komuna i obywatele (...) jałmużny nie ominęły żadnego biedaka, kim by nie był — cudzoziemcem czy przybyszem z [florenckiego] contado — udzielane stale i na miarę możliwości, jakie dyktowały niebotyczne ceny i głód. A że wielu bogatych, dobrych i pobożnych obywateli udzielało hojnych jałmużn, to musimy pokładać nadzieję w Bogu, że nie będzie spoglądał na ciężkie grzechy obywateli, w które, jak mówiliśmy to wcześniej, nasze miasto jest dobrze zaopatrzone, ale wynagrodzi nam za te jałmużny i tych dobrych i drogich obywateli, jeśli zechce okazać miłosierdzie, tak jak to uczynił ludziom z Niniwy; «albowiem jałmużna gasi grzech», powiedział Pan"158.

Te regularne, ściśle związane z kalendarzem liturgiczno-miejskim „ułaskawienia”, przeprowadzane kilkakrotnie w roku (na Boże Narodzenie, Wielkanoc, święto patrona miasta Jana Chrzciciela), miały za sobą co najmniej kilkudziesięcioletnią tradycję ${ }^{159}$. W 1348 r., by zapobiec groźbie masowej śmierci więźniów, uchwalono dwie dodatkowe amnestie: na Zesłanie Ducha Świętego (8 czerwca) i świętej Anny (26 lipca), który to dzień stawał się w tym czasie jeszcze jednym świętem patronalnym $^{160}$. Znaczenie tych amnestii daleko jednak wybiegało poza, jakbyśmy to dzisiaj określili, stałą politykę społeczną i penitencjarną i doraźne zmiany do niej wprowadzane. Ubrane w rytuał — niewolny od upokorzenia, jakim był przemarsz więźniów przez miasto od Stinche do baptysterium św. Jana Chrzciciela w papierowych mitrach na głowie, z nazwiskiem wypisanym wielkimi literami — były

\footnotetext{
${ }^{156} \mathrm{~W}$ ich opisie popełnia błąd, świadczący o tym, że interpolował go wspomnieniem z procesji organizowanych w czasie następnych wielkich epidemii $(1362,1374)$. Pisze bowiem o procesjach z ikoną zwaną Madonna dell'Impruneta, która znajdowała się w kościele w nieodległej od Florencji Imprunecie. Kult obrazu zaczął się na dobre po powodzi w 1333 r., w drugiej połowie XIV w. zaczął on pełnić funkcję florenckiego palladium. Pierwsze potwierdzenie o procesjach do i we Florencji z tą ikoną pochodzi jednak dopiero z 1354 r., z kroniki Matteo Villaniego.

157 Władze miejskie odpowiedzialne były także za właściwą i regularną posługę duchową w więzieniu, którą zazwyczaj spełniali bracia z klasztorów mendykanckich oraz tercjarze (pinzocheri), zajmujący się między innymi rozdziałem jałmużn czy asystą przy zamykaniu w Stinche kobiet. Jest więcej niż prawdopodobne, że więźniowie pozbawieni byli tej opieki przynajmniej przez część okresu zarazy. W zarządzeniu wydanym 6 IV 1349 r., w którym wyznaczono (za pensję) rektora kościoła San Simone (z obowiązkiem odprawiania jednej mszy dziennie w więzieniu) oraz jednego świeckiego z tej parafii do pełnienia owej posługi, mowa jest, iż od października 1348 r. więzienie — na skutek odmowy wyznaczonych do niej zakonników - było jej całkowicie pozbawione (ASF, Prov. Reg. 36, f. 72).

158 Giovanni Villani, Nuova Cronica, Lib. XIII, R. LXXIII; niedokładnie przytoczony cytat (,lla limosina spegne il peccato”; w Księdze Eklezjastyka, 3:33: „Ignem ardentem exstinguit aqua, sic eleemosyna expiat peccata”).

159 Pierwsza wzmianka dotyczy 1281 r., ale w 1294 r. mówi się o „starym zwyczaju”. Zob. szerzej, H. Manikowska, Nadzór i represja, s. 318-333.

16026 VII 1343 r. zwyciężyła rebelia przeciwko władzy tytularnego księcia Aten, Waltera (Gualtieri) z Brienne; on sam salwował się ucieczką.
} 
istotnym elementem relacji miasta z Bogiem i świętym patronem. Nazwane „ofiarą” (oblatio, offerta), zawierające także rytuał oczyszczenia, nazwany „chrztem” („,baptizati sive aqua perfusi”), gdy obejmowały one graczy hazardowych, uwalnianych także i znacznie częściej poza regularnymi amnestiami (na dziedzińcu więziennym polewano głowy więźniów wodą), były nie tylko aktem miłosierdzia wobec dłużników komuny ${ }^{161}$; były także, i przede wszystkim, darem składanym patronowi miasta $\mathrm{z}$ ich zobowiązań na rzecz skarbca komunalnego, z kosztów, jakie ten ponosił w związku z uwolnieniem więźniów. Byli oni ofiarowani „Deo et beato Johanni, aby dobro lepszym pomnażać, aby Pan nasz Jezus Chrystus zachował w dobrym stanie i pokoju miasto i komunę" ${ }^{162}$. Niedatowane, ale wpisane do Liber Fabarum z 1348 r. uzasadnienie dodatkowej amnestii z okazji dnia św. Anny, nie pozostawia wątpliwości, że także ona, jak i poprzednia, na Zesłanie Ducha Świętego, miały — dzięki okazanemu miłosierdziu i trosce o więźniów - wzmocnić relację miasta z Bogiem i świętymi patronami: „,...) zważywszy na niezmierzone dobro, jakie wyświadczył Jezus Chrystus w dzień świętej Anny, dając komunie wyzwolenie od tyranii księcia ateńskiego, usłyszawszy o głodzie i chorobach w więzieniu, a także propter infectionem aeris, qui magis inibi, quam in alio loco infectus est...."163.

$\mathrm{Z}$ kryminalnych akt sądowych daje się, choć z trudem, wydobyć dowody na to, że obok materialnych putridia, fastidia i bructure starano się usunąć z miasta i ukarać występki moralne i zbrodnie contra naturam, by położyć kres najcięższej obrazie Boga. Cienkie, z okresu panowania zarazy, akta kryminalne trybunałów sądowych ujawniają oto przestępstwa i przestępców, których do początku XV w. i ustanowienia specjalnej, wymierzonej w sodomię magistratury Ufficiali di Notte (1432) grzechu i przestępstwa określanych we Francji jako vice florentin, a w Niemczech czasownikowo jako florenzen - spotyka się w źródłach sądowych niezwykle rzadko. Obok sodomii relatywnie „,nadreprezentowane" w stosunku do lat poprzednich i późniejszych są także bluźnierstwo i cudzołóstwo. W latach 1352-1355 skazano ośmiu mężczyzn za sodomię, w 1368 dwu, w latach 1380-1383 — pięciu, czyli średnio dwu rocznie. Tymczasem w czasie zarazy 1348 r. oskarżono o to czterech mężczyzn, w tym jednego, któremu zarzucono morderstwo na „młodzieńcu” napotkanym na drodze do San Casciano i ukrycie obnażonych zwłok pod gaszonym wapnem - czyny dokonane po nieudanej próbie gwałtu na nim ${ }^{164}$. Pochodzącego ze Sieny mieszkańca parafii San Pier Scherragio, który strupavit wielu młodzieńców, głównie po zajazdach, za co płacił im i właścicielom tychże zajazdów, spalono na stosie w połowie maja ${ }^{165}$. Kilka osób (w tym funkcjonariusza komuny) w trzech sprawach oskarżono o bluźnierstwo, kilka spraw toczyło się o cudzołóstwo kobiet (w tym także połączone z prostytucją). W czasie zarazy wydano też wyrok skazujący, w dodatku wyegzekwowany, za gwałt na zamężnej służącej (famula), popełniony przez potężnego Tommaso di Rossello Strozziego, znanego lepiej

\footnotetext{
${ }^{161}$ Kara więzienia była w tym czasie jeszcze bardzo rzadko orzekana i z trudem dopiero wkraczała do systemu kar. Amnestionowanymi więźniami byli skazani na grzywnę, którzy jej nie uiścili i z tej racji zostali umieszczeni w Stinche lub dłużnicy komuny.

162 ASF, PR 4, f. 45 (1294 r.). Podobnie w provvisione dotyczącej dodatkowej amnestii w czasie głodu 1346/7: ,... ut multis miserabilibus personis cum maxima paupertate et intollerabili indigentia precipue propter carestiam nunc vigentem in ipsis comunis carceribus hactenus maceratis (...), et ut idem dominus noster Ihesus Christus civitatem Florentie in bono et pacifico statu manteneat et conservet et de bono in melius augmentare digentium (...)", ASF, Prov. Dup. 6, f. 156r-156v.

163 ASF, LF 28, f. 138r (całość zarządzenia do f. 139v). Zachowano pełny rytuał - przemarsz do Baptysterium z mitrami papierowymi, na których wypisane były nazwiska uwalnianych i ich przewiny. Amnestia miała mieć bardzo szeroki zasięg, uwalniano bowiem osoby nawet świeżo uwięzione (od poprzedniej amnestii upłynął zaledwie miesiąc) oraz dłużników ze zobowiązaniami do 25 £, jeśli uwięzieni byli przed 26 kwietnia (wtedy przeprowadzono amnestię wielkanocną). Dramat sytuacji w mieście oddają polecenia wydane podeście oraz sędziemu camerae et gabellae w drugiej połowie czerwca przez priorów cechów. Sędzia miał nie nakładać kary na wybranego przez nich urzędnika do przeprowadzenia oblacji więźniów (na święto Janowe), ponieważ choć zgodnie z prawem nie mógł objąć on tej funkcji, jego wybór był koniecznością z powodu śmierci właściwego funkcjonariusza komuny (ASF, AP 372, f. 11v). 21 czerwca dwukrotnie priorzy cechów zwracają się do podesty i tegoż sędziego gabelli, by ci niezwłocznie i nieprzerwanie wzywali i poszukiwali tych obywateli florenckich, których wybrano do przeprowadzenia tejże oblacji (tamże, f. $12 \mathrm{v}-13 \mathrm{v})$.

164 ASF, AP 335, f. 23v.

165 ASF, AP 279, f. 96.
} 
z nieco późniejszych zamówień dekoracji i ołtarza w rodowej kaplicy w kościele Santa Maria Novella u dwóch wielkich artystów florenckich tego czasu — Nardo di Cione i jego brata Andrei Orcagna ${ }^{166}$.

W XV w. usuwanie z miasta i niewpuszczanie doń prostytutek oraz zakaz uprawiania tu ich „,zawodu" w okresie zarazy związane były już wyraźnie z reżimem sanitarnym. W XIV stuleciu zakazy tego rodzaju podyktowane były przede wszystkim przez względy moralne i religijne. W kodyfikacji statutów florenckich (1322-1325) i poprzedzającym ją zarządzeniu z 1319 r. wyraźnie stwierdza się, że popełniają one wiele występków obrażających Boga i na szkodę honoru miasta ${ }^{167}$. Ten drugi aspekt - troska o honor miasta - był nie tylko nierozłączny z pierwszym, ale też tak samo ważny. Niedozwoloną prostytucję, przynoszącą mu ujmę, karano chłostą na obnażone ciało pędzonej przez miasto kobiety. ${ }^{168}$

Wydarzenia i sprawy ten honor manifestujące wymagały natomiast odpowiedniego splendoru. Nie zaprzestano więc na czas zarazy celebrowania uroczystości, które, choć niepozbawione oprawy religijnej, wynikały z kalendarza świeckiego, jak obsada głównych urzędów w mieście. Nowe kadencje wszystkich najważniejszych „urzędników cudzoziemskich” i ich familii rozpoczęły się, przypomnijmy, w szczytowym okresie zarazy ${ }^{169}$. Zachowano nawet uroczyste, z trąbami, witanie ich poza bramami miasta. ${ }^{170}$

To bodaj najsilniejszy kontrast $\mathrm{z}$ toposem zagłady, obrazem wymarłego, pogrążonego w ciszy świata, opuszczonej przez człowieka przyrody, puszczonych samopas zwierząt domowych. „Mogłeś zobaczyć, jak wioski i miasta jeszcze dzisiaj pełne ludzi, następnego dnia, gdy wszyscy je opuścili, zamierały pogrążone w głuchej ciszy. (...) Można by sądzić, że świat powrócił do pierwotnego stanu ciszy: nie słychać było żadnego głosu na polach, żadnego gwizdania pasterzy, żadnych dzikich zwierząt zasadzających się na trzodę, żadnego porywanego ptactwa domowego. Przejrzały zasiew na próżno oczekiwał żniwiarza; winny szczep utracił liście i złociły się nietknięte winogrona..." ${ }^{171}$ Boccaccio kroczy śladami wielkich poprzedników, zwłaszcza cytowanego wyżej Pawła Diakona: „Per la qual cosa essi, così nelli loro costumi come i cittadini divenuti lascivi, di niuna lor cosa o faccenda curavano; anzi tutti, quasi quel giorno nel quale si vedevano esser venuti la morte aspettassero, non d'aiutare i futuri frutti delle bestie e delle terre e delle loro passate fatiche, ma di consumare quegli che si trovavano presenti si sforzavano con ogni ingegno. Per che adivenne i buoi, gli asini, le pecore, le capre, i porci, i polli e i cani medesimi fedelissimi agli uomini, fuori delle proprie case cacciati, per li campi (dove ancora le biade abbandonate erano, senza essere, non che raccolte ma pur segate) come meglio piaceva loro se n'andavano. E molti, quasi come razionali, poi che pasciuti erano bene il

\footnotetext{
166 ASF, AP 335, f. 15r-15v. Sprawa w trybunale podesty zaczęła się jeszcze za kadencji Quirico, kończył ją już Salamone. Wyroki skazujące za gwałt dokonany przez ludzi potężnych zdarzały się relatywnie często, ale o wiele większą rzadkością były oskarżenia i skazania za gwałt na służącej (tu zapewne znaczenie miało to, że była zamężna, a jej mąż prawdopodobnie nie poszedł na żaden układ z gwałcicielem). Według badań C. Caduff (Magnati e popolani nel contado fiorentino. Dinamiche sociali e rapporti di potere nel Trecento, „Rivista di storia dell'agricoltura”, 33, 1993, nr 2, s. 39-43), „magnati” i generalnie mężczyźni o statusie szlacheckim byli sądzeni za gwałt czterokrotnie częściej niż popolani, co miało też związek z traktowaniem gwałtu jako „broni wojennej”, odbierającej honor wrogowi. Freski Nardo di Cione w kaplicy Strozzich miał zamówić i sfinansować Tommaso di Rossello w geście ekspiacji za inny grzech - lichwę.

167 Szerzej o tym Maria S. Mazzi, Prostitute e lenoni nella Firenze del Quattrocento, Milano 1991, s. 190 n.; zob. także, A. Carmichael, Plague, s. 98, 107; H. Manikowska, Nadzór i represja, s. 261-264. W czasie rewolty 1343 r. (wypędzenie księcia ateńskiego) tłum przypuścił atak na dom publiczny (postribulum publicum), ograbił go i wypędził prostytutki, zob. ASF, GA 50, f. 28 (16 V 1344).

168 Zob. dwa takie wyroki z wiosny 1348 r. ASF, AP 279, f. 31 i 38.

169 Miejscem składania przysiąg przez urzędników cudzoziemskich był sąsiadujący z Palazzo Vecchio kościół San Pier Scheraggio. Przysięgę składano na kilka dni przed objęciem urzędu. Por. przysięgę egzekutora sprawiedliwości (Cionarellus de Tamburellis) i całej jego familiae 10 I 1349, ASF, LF 29, f. 17v.

170 Zob. ASF, CCCU 45 (niepag.), wypłaty 27 lipca dla m. in. tubatore i trombetta, którzy wraz z heroldami konno wyprawiali się za bramę miasta, by oddać honory podeście Salamone, egzekutorowi sprawiedliwości Lodovico Cardoli, poprzedniemu podeście Quirico i obecnemu kapitanowi ludu Nicola Della Sera.

171 Paweł Diakon, Historia Longobardów, tłum. I. Lewandowski, Warszawa 1995, ks. II, 4, s. 224 n.
} 
giorno, la notte alle lor case senza alcuno correggimento di pastore si tornavano satolli.” Rzecz jasna, jest to u Boccaccia bardziej kadr odwrócenia porządku naturalnego niż zagłady ludzi. Na utarte tory wraca jednak później Marchionne: ,Żadnego z rzemiosł nie wykonywano już we Florencji; wszystkie warsztaty i sklepy, wszystkie tawerny były zamknięte, wyjątkiem były jedynie otwarte sklepy aptekarzy i kościoły. Przechodzień nie napotkał niemal innego człowieka. (...) nieutkana przędza i wełna walały się po mieście i w contado"172.

Cytowane fragmenty dzieł Pawła Diakona i Marchionne obrazują skutki zagłady „,nazajutrz po”. Boccaccio koncentruje się na niej „w trakcie”, na zarazie w jej apogeum. Niczego takiego nie znajdziemy w dokumentacji urzędowej z miesięcy zarazy. Lamenty na brak ludzi do pracy, kandydatów czy w ogóle chętnych do obsady ogromnej liczby urzędów i funkcji w mieście i państwie florenckim, na niemożność rozliczenia się ze skarbcem komuny z powodu braku dochodów, wysiłki, by uporać się z masowym sieroctwem, spisywanie ofiar we własnym środowisku, jak czyni to fra Paolo Bilenchi ${ }^{173}$, zaczynają się u samego schyłku rządów dżumy i przybierają na sile „nazajutrz po”.

Jest to dobrze widoczne także w księgach rodzinnych, spisywanych chętnie i w niemałej liczbie w ówczesnej Florencji. W cytowanej już Cronica domestica Donata Vellutiego, dzieła uznanego, nie bez racji, za szczytowe osiągnięcie wczesnego okresu rozwoju gatunku, napisanego między 1367 a 1370 rokiem (a więc już po dwóch wielkich epidemiach dżumy) przez zbliżającego się do sześćdziesiątki patrycjusza, czarna śmierć $1348 \mathrm{r}$. staje się w pewnym momencie opowieści punktem odniesienia dla losów członków jego rozrodzonego rodu: umiera się przed, w trakcie lub po grande moria. Cała jedna gałąź tego rodu wówczas wymarła (w sumie, ze wszystkich gałęzi wylicza 23 ofiary), Donato stracił także najbliższych ${ }^{174}$. Próżno jednak szukać w jego ricordi dowodu na percepcję szalejącej wokół zarazy jako zagłady ludzkości. Staranne wyliczenie przez Vellutiego zmarłych członków rodziny wynikało i z cech samego gatunku pisarstwa, w którym dane genealogiczne i o liczebności rodu należały do najważniejszych, i z sytuacji majątkowej, w jakiej znalazł się po czarnej śmierci.

Istotne przesunięcia w pozycji materialnej całych grup, nagła kumulacja wielkiego majątku przez jednostki i instytucje kościelne są w różny sposób ujawniane przez źródła. Największą uwagę badaczy przyciągnął ogromny dzięki legatom testamentowym przyrost majątku największego z bractw florenckich zajmujących się miłosierdziem, Orsanmichele. Mniej zajmowano się perturbacjami prawno-społecznymi, spowodowanymi legowaniem całości dóbr na rzecz instytucji kościelnych i dobroczynnych czy zagarnianiem majątku osieroconych dzieci i posagów mężatek ${ }^{175}$. Do sugerowanego przez Marchionne przewrotu klasowego: „bogaci stali się biedni, biedni zostali bogaczami”, którym, zauważmy na marginesie, uzasadniały swoje niektóre decyzje także władze florenckie, jednak nie doszło $^{176}$. Donato Velluti, jak wielu innych patrycjuszy florenckich ocalałych z zarazy, podjął skuteczną walkę o odzyskanie majątku po zmarłych krewnych, zbyt hojnych na łożu przedwczesnej śmierci dla instytucji dobroczynnych i Kościoła. Obszerny passus w jego Kronice domowej poświęcony losom własnym i rodziny w czasie czarnej śmierci — obraz miasta i samej zarazy jest w nim w głębokim tle - jest niemal księgowym zestawieniem wierzytelności i długów, a przede wszystkim niezwyk-

\footnotetext{
172 Marchionne, s. 232.

173 Szerzej o sytuacji „nazajutrz po”, zob. cyt. artykuł Falsiniego.

174 Donato Velluti, Cronica domestica, passim i zamieszczona przez wydawcę tablica genealogiczna. O śmierci swojego stryja Gerarda w wiejskiej posiadłości pisał, że zmarł w opuszczeniu: „non essendo persona collui”, ponieważ nie żyła już w tym momencie żona i większość dzieci. Dla porównania, w innych rodach patrycjuszowskich: Ferrucci stracili 18 osób, Frescobaldi - 12, zob. A.B. Falsini, Firenze dopo il 1348, s. 435.

175 ASF, Prov. Reg. 36, f. 3 (29 VIII 1348).

176 Marchionne, s. 232; ASF, Prov. Reg. 36, f. 16 (w zarządzeniu z 9 X 1348 r. pada identyczne sformułowanie); A.B. Falsini, Firenze dopo il 1348, s. 449. W największym florenckim cechu, wełny (Arte della Lana) wzrost płac był jednak tak szybki i wysoki, że trzeba było powołać już w grudniu specjalną komisję do ich ustabilizowania, F. Franceschi, Oltre il „,tumulto”. I lavoratori fiorentini dell'Arte della Lana fra Tre e Quattrocento, Firenze 1993, Biblioteca di Storia Toscana Moderna e Contemporanea, Studi e Documenti, t. 38, s. 159.
} 
le dlań korzystnego przepływu majątku w związku ze śmiercią krewnych ${ }^{177}$. Zarobił na nim 2 tys. florenów, co pozwoliło mu wykupić od bractwa Orsanmichele majątek brata i wygasłej gałęzi rodu, legowany w czasie zarazy. Kończy więc tę wyliczankę nieprzystającym, zdawałoby się, do dramatu miasta dziękczynieniem: „Onde, lodato sia Iddio sempre, avendo quello che ò in case, terre, masserizie e contanti, molto ò lui a ringraziare, potendomi molto bene passare"178.

\section{$\mathrm{V}$ \\ Zakończenie}

Obraz ukazujący dynamiczną, zmieniającą się z dnia na dzień płaszczyznę sprawowania władzy, egzekucji prawa, funkcjonowania urzędów, skomponowany na podstawie „dokumentacji oficjalnej” jest rzeczywiście odległy, a miejscami sprzeczny z tym, jaki odmalowują źródła narracyjne. Uznanie tego pierwszego za odbicie wprost realności, a tego drugiego za opis operujący konwencją literacką, zbudowany z ugruntowanych w tradycji literackiej i kronikarskiej toposów, za ekfrazę podporządkowującą swoim kanonom autorów tych opisów, prowadzi badaczy „prawdy historycznej” — rzeczywistości historycznej, takiej jaką ona była — na manowce weryfikacji „wiarygodności” narracji literackich i kronikarskich. Zbiurokratyzowanym rządom, a po części także zbiurokratyzowanym relacjom społecznym, ich na niebywałą w średniowieczu skalę upiśmiennieniu w miastach włoskich zawdzięczamy możliwość dostrzeżenia istoty różnicy między tymi obrazami. Gniew Boży, niespotykana dotąd, i nie do wyobrażenia wcześniej śmiertelność (zagłada ludzkości u Petrarki i fra Paolo Bilenchiego) to powszechna percepcja czarnej śmierci ex post, po jej ustąpieniu i przy kolejnych nawrotach - przekazana nam nie tylko w kronikach i „Prologu”, ale także w formularzowych zapisach decyzji i czynności władz. Upadek wszelkiego ładu, praw Bożych i ludzkich, chaos, konieczne w opisie tak percypowanej zarazy, są natomiast zupełnie nieobecne w dokumentacji urzędowej wytworzonej w czasie jej trwania. Jak sądzę, nie dlatego, że nie można ich było z perspektywy bieżących wydarzeń dostrzec czy to jako realność, czy tylko jako zagrożenie. W interpretacji tego „braku” pierwszorzędne znaczenie mają cechy gatunkowe obu typów źródeł, ich całkowicie odmienna ,poetyka”, oraz odrębność czasu powstania, motywów i celów ich autorów. Opisy czarnej śmierci wyrażają, wzmacniają i w jakimś stopniu na nowo, w stosunku do wcześniejszych topoi, kształtują percepcję zniszczeń, jakie ona niesie, widocznych w pełnej skali dopiero po jej ustąpieniu. Źródła urzędowe oddają obraz zmagań z nią i jej zagrożeniami hic et nunc — działań podejmowanych, a przede wszystkim dokumentowanych na piśmie przez ludzi władzy kierujących się nie tylko identyczną, jak pisarze i kronikarze percepcją zarazy i zmieniającymi ją bieżącymi doświadczeniami, ale także, i być może na pierwszym miejscu, rutyną władzy. Ta zaś była efektem niezwykłej w ówczesnej Europie — co do skali upowszechnienia i poziomu - kultury prawnej rządów komunalnych. Przekonanie o możliwości i konieczności regulowania życia obywateli przez prawo, owa tak dobrze widoczna w opasłych tomach statutów komunalnych i rozporządzeń władz, w tysiącach liczonych księgach sądowych, obejmujących ledwie półwiecze, „omnipotencja prawa”, „dyktatura” procedur i formularza notarialnego znajdują pełne potwierdzenie $\mathrm{w}$ dokumentacji wytworzonej $\mathrm{w}$ miesiącach panowania we Florencji czarnej śmierci. Choć z pewnością utraciły one wówczas nieco ze swojej mocy. Retoryka i przeznaczenie dokumentacji urzędowej z góry przesądzały o tym, że to co poza rutyną, procedurą, „normalnym” biegiem spraw znajdowało się w niej na marginesie, przysłonięte przez formularz utrudniający dotarcie do „nienormalności” czasów zarazy i jej percepcji.

„Prolog” Boccaccia, jak się miało rychło okazać, ożywił starą tradycję literacką pisania o zarazie i w końcu na dobre ją przyćmił. Na gruncie naukowej historiografii podyktował kwestionariusz badań

177 Donato Velluti, Cronica domestica, s. 190-191.

178 Tamże, s. 192: „Toteż, niech zawsze będzie chwalony Bóg, bowiem posiadając to, co posiadam w domach, ziemi, sprzętach domowych i w gotówce, i mogąc bardzo dobrze żyć, wielkie winienem Mu dziękczynienie". 
nad czarną śmiercią. Trzeba mieć jednak świadomość, że ten tak potężnie przemawiający do wyobraźni i ją modelujący opis odnosi się do innej płaszczyzny rzeczywistości zarazy niż dokumentacja archiwalna, pozostawiona nam przez liczne magistratury florenckie. Sięganie po tę drugą, by zweryfikować, z reguły negatywnie, obraz zawarty w Dekameronie, nie ma, moim zdaniem, naukowego uzasadnienia i nie może prowadzić do przekonania o wyższości w warsztacie historyka źródeł ,pewnych”, za jakie uznaje się dokumentację urzędową, nad źródłami literackimi. Oba typy, by przypomnieć tu konstatację banalną, wymagają po prostu odmiennej lektury i analizy, i odmiennego zastosowania. Dająca się wydobyć z archiwaliów „normalność” zjawisk, działań, zachowań i postaw oraz silnie eksponowana w opisach literackich i kronikarskich ich „nienormalność” tworzą dyptyk, który, gdy oglądany razem i jednocześnie w jego swoistej integralności, podsuwa nam bardziej wyrazisty i kompletny obraz czasów zarazy. Oba typy źródeł są także niezbędne, by móc dotrzeć do świadomości i świata wyobrażeń piszącego kilkadziesiąt lat po czarnej śmierci florenckiego patrycjusza, Giovanniego di Pagolo Morellego, który udzielając rad swoim synom, jak zachować się w czasie zarazy, przywołuje jej obraz sięgając do Dekameronu, a nie własnych doświadczeń z epidemii 1400 r.

\section{Literary topos or reality? About The Black Death in The Decameron once again}

The Introduction of The Decameron contains the most universally known for centuries description of Black Death - the devastation it caused in Florence in the spring and summer of 1348. In pertinent research conducted by historians it became a point of departure and reference, and, at the same time, the object of thorough studies on its concurrence with ,reality”. The author abandons this research tradition and confronts two types of sources: literary, chronicle and diary narration, on the one hand, and documents produced by Florentine offices (including court documents up to now studied to a slight extent), on the other hand, in order to capture within them the perception of the plague from the moment of its advance to the first months after its remission.

A comparative analysis of these sources deals with a number of problems, enabling the extraction of the differences of their topoi and rhetoric as well as the purposes for which they were created.

The author's reflections concern: The Introduction as an historian's source, the dynamics of the plague, and the activity of the authorities to be captured in official documentation, „normalcy” at the time of the plague, and the perception of Back Death (Boccaccio's' catalogue of attitudes towards the plague, the topos of the helplessness of medicine and physicians and its functioning after Black Death, the topos of the death of the abandoned victims and shameful burial, the topos of annihilation and the documents and undertakings of the authorities). Official documentation dating from the whole period of the plague, produced on a daily basis and encased in the rigid legal formulary and the routine of the authorities, cannot be used for examining the reliability of literary narration or chronicles, which operated with a cumulated image of Back Death at the time of its apogee and the destruction that emerged after its remission. Both types of sources are complementary and offer the researcher a holistic diptych of the perception of the plague, allowing him to better understand the role of old literary topoi, which Boccaccio endowed with new force and significance.

Kontakt do autora: hmanik@supermedia.pl 